•神农架世界自然遗产地专题・

\title{
神农架世界自然遗产地动物模式标本名录
}

\author{
周友兵 余小林 吴 楠申国珍 熊高明 徐文婷 \\ 㚞大勇 赵常明 谢宗强
}

(中国科学院植物研究所植被与环境变化国家重点实验室, 北京 100093)

\begin{abstract}
摘要: 模式标本作为新种发表与物种名称的依附实体, 具有极高的学术价值。湖北神农架作为华中地区的最高点, 历来受到博物学家的青睐。本文通过对历史文献的收集与整理, 确定了以采自神农架的标本为模式确立的动物物 种, 编制了“神农架世界自然遗产地动物模式标本名录”。以神农架世界自然遗产地采集的模式标本命名的正式发 表动物物种275种, 隶属于3门5纲22目91科170属。神农架模式标本物种的采集最早可追溯到1960年, 此后出现两 个采集高峰期, 即1977-1986和2009年。模式物种的发表略有滞后, 从当年发表到最长滞后34年, 但主要还都集中 在采集后的10年内(222种, 占80.73\%)。采集于神农架的模式标本物种发表在163条文献上, 从2006年开始发表在外 文期刊上的物种数在逐步增加, 而以中文发表的物种数在减少。以国内学者独立发表的物种较多 (245种, 占 89.09\%), 而国外学者和国内外学者联合发表的物种相对较少。模式标本当前实际被存放在62家机构或被私人收 藏, 在45家机构中, 以国内单位为主, 而17家私人收藏机构则以国外为主。本文对神农架世界自然遗产地动物模式 标本名录的汇总整理, 可为神农架世界自然遗产地履行联合国教科文组织世界遗产中心的要求, 进一步开展神农 架遗产的管理与保护提供依据。近年来关于神农架新物种的不断发表表明遗产地的物种多样性仍然存在被低估的 可能, 暗示着遗产地这方面的工作仍需进一步扩大和深入。
\end{abstract}

关键词: 模式标本; 神农架世界自然遗产; 新种; 正模; 副模

\section{A catalogue of animal type specimens from the Shennongjia World Natural Heritage Site, China}

Youbing Zhou, Xiaolin Yu, Nan Wu, Guozhen Shen, Gaoming Xiong, Wenting Xu, Dayong Fan, Changming Zhao, Zongqiang Xie*

State Key Laboratory of Vegetation and Environmental Change, Institute of Botany, Chinese Academy of Sciences, Beijing 100093

\begin{abstract}
Type specimens provide the taxonomic basis for publishing and naming new species, and thus have scientific importance. Mt. Shennongjia is the highest mountain in Central China, and its unique fauna and flora have attracted global attention and interest from naturalists for centuries. Based on historical literature, we provide an updated catalogue of animal type specimens from the Shennongjia World Natural Heritage Site, where a total of 275 species of type specimens belonging to 3 phyla, 5 classes, 22 orders, 91 families, and 170 genera have been collected. The first catalogue of type specimens in Shennongjia occurred in 1960, with two subsequent peaks in collection occurring in 1977-1986 and in 2009. The time delay between collection and publication varied from 0 to 34 years, however, most type descriptions were published within 10 years of collection (222, 80.73\%). Species were published in 163 scientific papers, mostly authored by domestic scholars (245, 89.09\%). These type specimens are currently deposited across 62 institutions and in private collections. Our comprehensive and integrative curation of these animal type specimens meets the requirements of the World Heritage Centre, United Nations Educational, Scientific and Cultural Organization, to further improve site management and conservation. Recent publications described several new species, suggesting that the number of species in the Shennongjia World Natural Heritage Site may have been
\end{abstract}

收稿日期: 2017-02-09; 接受日期: 2017-05-03

基金项目: 中国科学院科技服务网络计划(STS 计划) (KFJ-SW-STS-167)

* 通讯作者 Author for correspondence. E-mail: xie@ibcas.ac.cn 
underestimated and further surveys should be undertaken in the future.

Key words: type specimens; Shennongjia World Natural Heritage Site; new species; holotype; paratypes

模式标本作为新种发表与物种名称的依附实 体, 历来是分类学家从事系统分类研究必不可少的 科学依据, 也是开展专科专属研究、编写全国和地 方生物志、进行生物区系调查研究、开发、利用和 保护生物资源的重要基本资料(徐阳, 1992; 杨集昆, 1997; 崔俊芝等, 2007, 2009; 白明等, 2014)。模式标 本的数量是一个国家或地区分类学研究积累的重 要反映, 数量越多说明该地区的研究越深入, 受关 注度越高, 对分类与区系研究越有利(徐阳, 1992; 罗粀, 1998)。因此, 模式标本具有极高的学术价值 和保藏价值。神农架作为华中地区的最高点, 历来 受到分类学家的青睐, 18 世纪后, 国内外科学家对 神农架开展过多次科学考察, 采集并命名了很多动 植物物种(朱兆泉和宋朝枢, 1999; 廖明尧, 2012, 2015)。本文通过对历史文献资料的整理, 将采自神 农架世界自然遗产地的模式标本按分类系统、定名 人、原始文献、标本数量以及标本存放机构等格式 整理成文, 以期对神农架世界自然遗产地开展进一 步保护提供科学参考。

\section{1 方法}

本研究区域位于湖北神农架世界自然遗产地 内, 详细信息见谢宗强等(2017)。

本文模式标本数据来源: (1)以“Shennongjia”和 “New species”在Scholar Google (http://scholar.google. $\mathrm{com} /$ ) 和Web of Science (www.isiknowledge. com)网 站上搜索英文文献; (2) 以“神农架”和 “新种”在 Scholar Google、中国知网(http://www.cnki.net/)和维 普(http://www.cqvip.com/)网站上搜索中文文献; (3) 查阅相关的志书(杨星科等, 1991; 杨星科, 1997; 崔 俊芝等, 2007, 2009; 白明等, 2014)和专题网站(中 国昆虫模式标本数据库 http://www.zoology.csdb. cn/page/showEntity.vpage?uri=specimen.specimen 和 中国昆虫新种数据库 http://www.zoology.csdb.cn/ page/showEntity.vpage?uri=newinsect.species1)。本文 仅统计正式发表的物种, 对于硕博士学位论文中命 名的新种并未列入 (黄敏, 2003; 张莉莉, 2005; 黄蓬 英, 2005; 张志升, 2007; 刘经贤, 2009; 钟义海, 2010;
李泽建, 2013)。

文中模式标本名录按拉丁名、定名人、中文名、 原始文献[文献编号]、标本数量和产地以及标本存 放机构(英文缩写)列出(附录1)。原始文献的编号见 附录 2 。标本数量列出了正模、配模和副模的数量 与性别。动物模式标本存放地英文缩写见附录3。

\section{2 结果}

\section{1 种类组成}

以神农架世界自然遗产地采集的模式标本命 名的正式发表动物物种 275 种, 隶属于 $3 门 5$ 纲 22 目 91科170属(附录1)。其中, 节肢动物门的昆虫纲和蛛 形纲的种类较多, 而缓步动物门和脊索动物门均只 有 1 个种。在目水平上, 双翅目、鞘翅目和蜘蛛目种 类较多, 分别是 $82 、 37$ 和 30 种, 各占总种数的 $29.82 \% 、 13.45 \%$ 和 $10.91 \%$ (表1)。

\section{2 标本采集与发表文献分析}

在神农架采集的模式标本物种最早可追溯到 1960年四川阿坝州卫生防疫站的陈家贤先生采集 到的双凹纤蚤 (Rhadinopsylla (Actenophthalmus) blconcava)。此后出现2个采集高峰期, 即1977-1986 和2009年, 其中 2009 年主要是中国农业大学刘启飞 先生采集的舞虹科的种类。模式标本物种的发表时 间从1979年开始，在1997年和 2010 年出现 2 个高峰 (图1)。其中, 1997年主要是由于杨星科先生《长江 三峡库区昆虫》的出版, 发表了20余种神农架模式 物种; 2010年主要是由于发表了刘启飞先生2009年 采集的27种舞虹科的模式物种。模式物种从采集到 发表的时间间隔从当年发表到最长34年, 但各个物 种的发表主要还是集中在模式标本采集后的10年 内(222种，占 $80.73 \%)$ (图2)。

采集于神农架的模式标本物种发表在163条文 献上(附录2)。其中，中文期刊文献115篇，外文期刊 文献46篇, 专著类文献2部。以中文和外文发表的物 种数分别是 212 和 63 , 且从2006年开始发表在外文 期刊上的物种数在逐步增加, 而以中文发表的物种 数在减少(图3)。对发表的作者分析表明, 以国内学 者独立发表的物种为主(245种，占89.09\%), 国外学 
表1 神农架世界自然遗产地动物模式标本的种类组成

Table 1 Composition of animal type specimens in the Shennongjia World Natural Heritage Site, China

\begin{tabular}{lll}
\hline 分类 & 物种数 & 百分比 \\
Classes & Number of species & Percentage (\%) \\
\hline 缓步动物门 Tardigrada & & \\
真缓步纲 Eutardigrada & & \\
$\quad$ 近爪目 Parachela & 1 & 0.36 \\
节肢动物门 Arthropoda & & \\
少足纲 Pauropoda & & \\
四少足目 Tetramerocerata & 1 & 0.36 \\
蛛形纲 Arachnida & & \\
真螨目 Acaritiformes & 6 & 2.18 \\
寄螨目 Parasitiforme & 13 & 4.73 \\
蜘蛛目 Araneae & 30 & 10.91 \\
昆虫纲 Insecta & & \\
原尾目 Protura & 3 & 1.09 \\
蜻蜓目 Odonata & 5 & 1.82 \\
襀翅目 Plecoptera & 4 & 1.45 \\
直翅目 Orthoptera & 12 & 4.36 \\
禹目 Anoplura & 1 & 0.36 \\
姃翅目 Thysanoptera & 2 & 0.73 \\
同翅目 Homoptera & 5 & 1.82 \\
半翅目 Hemiptera & 10 & 3.64 \\
脉翅目 Neuroptera & 12 & 4.36 \\
鞘翅目 Coleoptera & 37 & 13.45 \\
长翅目 Mecoptera & 1 & 0.36 \\
双翅目 Diptera & 82 & 29.82 \\
蚤目 Siphonaptera & 7 & 2.55 \\
毛翅目 Trichoptera & 1 & 0.36 \\
鳞翅目 Lepidoptera & 18 & 6.55 \\
膜翅目 Hymenoptera & 23 & \\
脊索动物门 Chordata & & \\
硬骨鱼纲 Osteichthyes & & \\
鲇形目 Siluriformes & 1 & \\
\hline
\end{tabular}

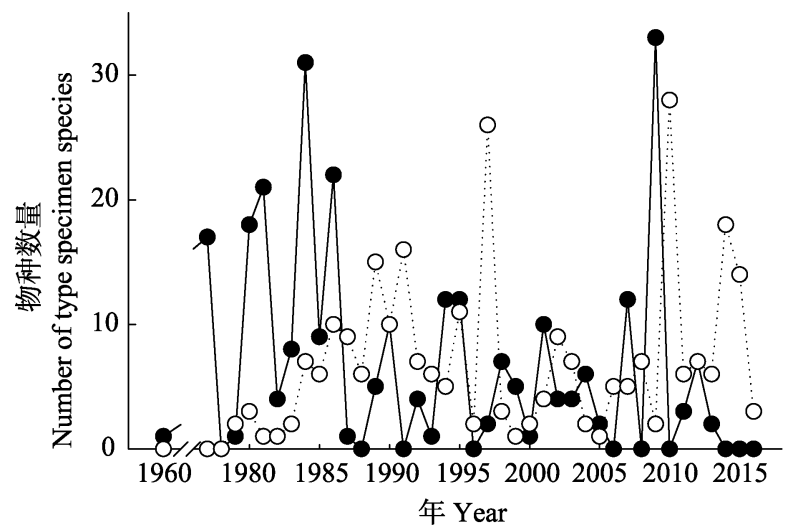

图1 神农架世界自然遗产地每年动物模式标本采集(实心 圆)与动物模式物种发表(空心圆)的数量

Fig. 1 Number of animal type specimens collected (dark circles) and published (open circles) in the Shennongjia World Natural Heritage Site, China.

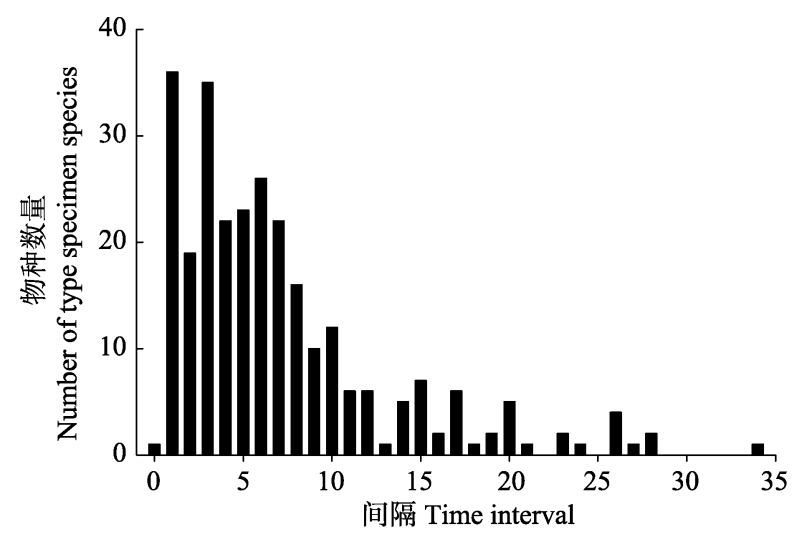

图2 神农架世界自然遗产地动物模式标本采集与发表间隔 的年数

Fig. 2 Time interval between collection and publishing of animal type specimens from the Shennongjia World Natural Heritage Site, China

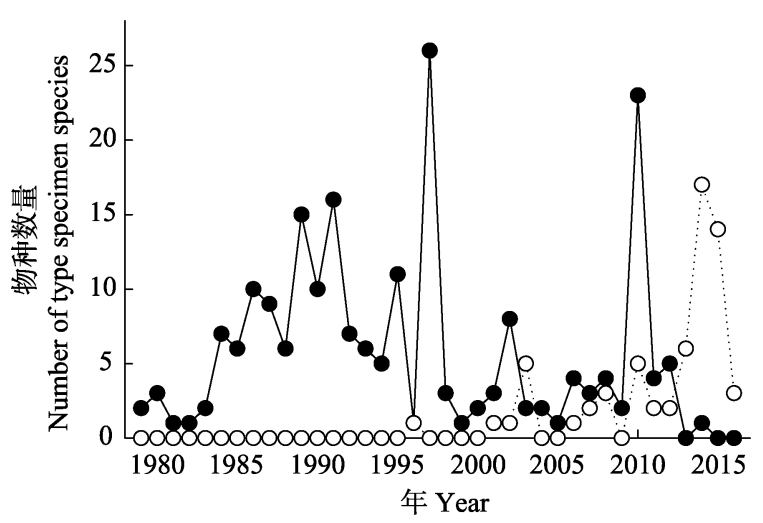

图3神农架世界自然遗产地每年发表在中文(实心圆)和外 文(空心圆)文献上的动物模式标本物种数量

Fig. 3 Number of animal type specimens published in Chinese (dark circles) and western literature (open circles) from the Shennongjia World Natural Heritage Site, China

者和国内外学者联合发表的物种分别是14和16种, 各占5.09\%和5.82\%。

\section{3 标本存放地}

在模式物种发表的原始文献中, 列出的模式标 本存放地为84处。由于近年来国内单位合并与名称 的变更, 这些标本当前实际存放在62家机构或被个 人收藏(附录3)。其中, 45 家机构主要是高校(26)、博 物馆(9)、科研院所(9)与政府部门(1)。国内机构收 藏的标本较多, 中国农业大学和中国科学院动物研 究所收藏的标本最多, 分别有 83 和 54 种; 而9家境 外机构收藏的标本较少, 累计仅为14种。在17家私 人收藏中, 仅有一家是国内藏家, 其余均为国外, 主要是意大利和德国藏家。 


\section{3 讨论}

本文通过收集整理近年来的研究资料发现，从 神农架采集命名的动物模式标本物种 $3 门 5$ 纲 22 目 91科170属275种, 形成了神农架世界自然遗产地的 动物模式标本名录, 可为其履行世界遗产中心的要 求(http://whc.unesco.org/en/decisions/6786), 进一步 开展神农架遗产的监测与保护提供依据。

影响一个地区模式标本种类数量的因素有多 种(王绍能等, 2011; 曹成全等, 2013)。首先, 该地区 物种(尤其是本地特有物种)的多少, 当一个地区的 物种越多时, 在研究程度相当的情况下, 记录到的 模式标本种类往往也会较多。其次, 在该地区开展 区系研究的时间和次数, 与具有相同或类似区系组 成的邻近地区相比, 如果一个地区开展系统区系研 究的时间越早且次数越多, 则记录到的模式标本种 类也会越多。再次, 与该地区区系研究的深度与研 究者关注对象有关, 往往研究得越深, 关注对象越 广, 记录的模式物种越多, 发现稀有物种的可能性 越大。

尽管研究人员已对神农架开展过多次大规模 调查研究(朱兆泉和宋朝枢, 1999; 廖明尧, 2012, 2015), 但近年来关于神农架的新种仍不断被发现 (图2), 且图2也显示发表到2016年的物种都是在 2013年之前采集的标本。此外, 本文没有列入的硕博 士论文中尚有 42 个物种未正式发表(陈明利, $2002^{(1)}$; 黄敏, 2003; 张桂玲, $2003^{(2)}$; 张艳, $2004^{(3)}$; 张莉莉, 2005; 黄蓬英, 2005; 张志升, 2007; 牛耕耘, $2008^{\circledR}$; 刘经贤, 2009; 赵赴, $2010^{5}$; 钟义海, 2010; 李泽建, 2013)。这一方面说明了神农架世界自然遗产地动物 资源丰富多样、特有种类多, 另一方面也意味着神 农架世界自然遗产地动物的物种多样性仍然存在 被低估的可能。因此, 神农架动物的调查分类工作 还需要继续扩大和深入, 进一步明确其生物多样性 的现状。同时, 应加强这些物种生态环境的保护以

(1) 陈明利 (2002) 中国钩瓣叶蜂属系统分类研究. 硕士学位论文, 中南 林业科技大学, 长沙.

(2) 张桂玲 (2003) 中国蓟马科分类研究. 硕士学位论文, 西北农林科技 大学, 杨凌.

(3) 张艳 (2004) 中国圆胸隐翅虫属分类研究 (鞘翅目: 隐翅虫科: 尖腹 隐翅虫亚科). 硕士学位论文, 上海师范大学, 上海.

(4) 牛耕耘 (2008) 侧跗叶蜂属系统分类研究. 硕士学位论文, 中南林业 科技大学, 长沙.

(5) 赵赴 (2010) 湖北神农架叶蜂亚科区系地理初步研究. 硕士学位论 文, 中南林业科技大学, 长沙.
及生物多样性保护, 为神农架世界自然遗产地保护 的具体实施提供科学建议。

致谢: 湖北神农架国家级自然保护区管理局、湖北 神农架森林生态系统国家野外科学观测研究站、中 国科学院水生生物研究所张浩永博士、华中农业大 学刘晓艳博士提供了部分文献, 中国科学院植物研 究所研究生雷博宇、陈文文、崔继法帮助查找了部 分文献, 英国牛津大学的Chris Newman博士对英文 摘要进行了润色, 在此一并致谢。

\section{参考文献}

Bai M, Cui JZ, Hu JY, Li LZ (2014) Catalogue of the Insect Type Specimens Deposited in China, Vol. 3. China Forestry Publishing House, Beijing. (in Chinese) [白明, 崔俊芝, 胡 佳耀, 李利珍 (2014) 中国昆虫模式标本名录(第3卷). 中 国林业出版社, 北京.]

Cao CQ, Chen SZ, Tong C (2013) A checklist of type specimens of insect from Mount Emei of Sichuan Province. Journal of Leshan Normal University, 28(12), 38-45. (in Chinese with English abstract) [曹成全, 陈申芝, 童超 (2013) 四川峨眉山昆虫模式标本名录. 乐山师范学院学 报, 28(12), 38-45.]

Cui JZ, Bai M, Fan RJ, Wu H (2009) Catalogue of the Insect Type Specimens Deposited in China, Vol. 2. China Forestry Publishing House, Beijing. (in Chinese) [ 崔俊芝, 白明, 范 仁俊, 吴鸿 (2009) 中国昆虫模式标本名录(第2卷). 中国 林业出版社, 北京.]

Cui JZ, Bai M, Wu H, Ji LQ (2007) Catalogue of the Insect Type Specimens Deposited in China, Vol.1. China Forestry Publishing House, Beijing. (in Chinese) [崔俊芝, 白明, 吴 鸿, 纪力强 (2007) 中国昆虫模式标本名录(第1卷). 中国 林业出版社, 北京.]

Huang M (2003) Systematic Study of Typhlocybini from China (Homoptera: Cicadellidae: Typhlocybinae). PhD dissertation, Northwest Sci-tech University of Agriculture and Forestry, Yangling. (in Chinese with English abstract) [黄敏 (2003) 中国小叶蝉族分类研究(同翅目: 叶蝉科: 小叶蝉 亚科). 博士学位论文, 西北农林科技大学, 杨凌.]

Huang PY (2005) Systematics of Mecoptera from China. PhD dissertation, Northwest Sci-tech University of Agriculture and Forestry, Yangling. (in Chinese with English abstract) [黄蓬英 (2005) 中国长翅目昆虫系统分类研究. 博士学 位论文, 西北农林科技大学, 杨凌.]

Li ZJ (2013) Systematic Study of Macrophya Dahlbom (Hymenoptera: Tenthredinidae). PhD dissertation, Central South University of Forestry \& Technology, Changsha. (in Chinese with English abstract) [李泽建 (2013) 钩瓣叶蜂属 (Macrophya Dahlbom)系统学研究. 博士学位论文, 中南 
林业科技大学, 长沙.]

Liao MY (2012) Annals of Shennongjia Nature Reserve. Hubei Science and Technology Press, Wuhan. (in Chinese) [廖明 尧 (2012) 神农架自然保护区志. 湖北科学技术出版社, 武汉.]

Liao MY (2015) Comprehensive Survey Report of Natural Resources in Shennongjia Area. China Forestry Publishing House, Beijing. (in Chinese) [廖明尧 (2015) 神农架地区 自然资源综合调查报告. 中国林业出版社，北京.]

Liu JX (2009) A Taxonomic Study on the Subfamily Pimplinae (Hymenoptera: Ichneumonidae) from China. PhD dissertation, Zhejiang University, Hangzhou. (in Chinese with English abstract) [刘经贤 (2009) 中国瘤姬蜂亚科分类研究. 博士学位论文, 浙江大学, 杭州.]

Luo T (1998) Catalogue of the mammal type specimens preserved in the mammal collection of the Institute of Zoology, Chinese Academy of Sciences. Acta Zootaxonomica Sinica, 23, 333-335. (in Chinese) [罗䑣 (1998) 中国科学院动物 研究所兽类标本馆藏模式标本名录. 动物分类学报, 23, 333-335.]

Wang SN, Pan D, Wen ZH, Huang JH (2011) A checklist of type specimens of insects from Maoershan Nature Reserve of Guangxi, China. Journal of Guangxi Normal University (Natural Science Edition), 29(4), 122-131. (in Chinese with English abstract) [王绍能, 潘冬, 文忠华, 黄建华 (2011) 广西猫儿山自然保护区昆虫模式标本名录. 广西师范大 学学报(自然科学版), 29(4), 122-131.]

Xie ZQ, Shen GZ, Zhou YB, Fan DY, Xu WT, Gao XM, Du YJ, Xiong GM, Zhao CM, Zhu Y, Lai JS (2017) The outstanding universal value and conservation of the Shennongjia World Natural Heritage Site. Biodiversity Science, 25, 490-497. (in Chinese with English abstract) [谢宗强, 申国 珍, 周友兵, 樊大勇, 徐文婷, 高贤明, 杜彦君, 熊高明, 赵常明, 祝燕, 赖江山 (2017) 神农架世界自然遗产地的 全球突出普遍价值及其保护. 生物多样性, 25, 490-497.]

Xu Y (1992) Allotype management in academic research. Archives Science Bulletin, (5), 37-41. (in Chinese) [徐阳 (1992) 科学研究中模式标本档案的管理. 档案学通讯,

\section{(5), 37-41.]}

Yang JK (1997) Allotype should be appointed as far as possible. Acta Zootaxonomica Sinica, 22, 441. (in Chinese) [杨集 昆 (1997) 模式标本中宜尽量指定配模. 动物分类学报, 22, 441.]

Yang XK (1997) Insects of the Three Gorge Reservoir Area of Yangtze River. Chongqing Publishing House, Chongqing. (in Chinese) [杨星科 (1997) 长江三峡库区昆虫. 重庆出 版社, 重庆.]

Yang XK, Sun HG, Jiang GM (1991) Catalogue of the Insect Type Specimens Deposited in Institute of Zoology, Chinese Academy of Sciences. China Argiculture Press, Beijing. (in Chinese) [杨星科, 孙洪国, 江国妹 (1991) 中国科学院动 物研究所昆虫标本馆藏模式标本名录. 中国农业出版社, 北京.]

Zhang LL (2005) A Systematic Study on Dolichopodinae from China (Diptera: Dolichopodidae). PhD dissertation, China Agricultural University, Beijing. (in Chinese with English abstract) [张莉莉 (2005) 中国长足䗒亚科系统分类研究 (双翅目: 长足虹科). 博士学位论文, 中国农业大学, 北京.]

Zhang ZS (2007) Study on the Systematics of the Spider Families Agelenidae and Amaurobiidae from China (Arachnida: Araneae). PhD dissertation, Hebei University, Baoding. [张 志升 (2007) 中国漏斗蛛科和暗蛛科的系统学研究. 博 士学位论文, 河北大学, 保定.]

Zhong YH (2010) Systematica Study of Pachyprotasis Hartig from China (Hymenoptera: Tenthredinidae). PhD dissertation, Central South University of Forestry \& Technology, Changsha. (in Chinese with English abstract) [钟义海 (2010) 中国方颜叶蜂属系统分类研究. 博士学位论文, 中南林业科技大学, 长沙.]

Zhu ZQ, Song ZS (1999) Scientific Survey of Shennongjia Nature Reserve. China Forestry Publishing House, Beijing. (in Chinese) [朱兆泉, 宋朝枢 (1999) 神农架自然保护区 科学考察集. 中国林业出版社, 北京.]

(责任编委: 黄晓否 责任编辑: 问文杰)

\section{附录 Supplementary Material}

附录1 神农架世界自然遗产地动物模式标本名录

Appendix 1 Checklist of animal type specimens in the Shennongjia World Natural Heritage Site, China http://www.biodiversity-science.net/fileup/PDF/2017032-1.pdf

\section{附录2 神农架世界自然遗产地动物模式标本发表的原始文献}

Appendix 2 Checklist of original references recording type specimens in the Shennongjia World Natural Heritage Site, China http://www.biodiversity-science.net/fileup/PDF/2017032-2.pdf

\section{附录3 神农架世界自然遗产地动物模式标本存放地中英文名称及缩写}

Appendix 3 List of abbreviation, Chinese and English names of deposit sites of animal type specimens collected from the Shennongjia World Natural Heritage Site http://www.biodiversity-science.net/fileup/PDF/2017032-3.pdf 
周友兵, 余小林, 吴楠, 申国珍, 熊高明, 徐文婷, 焚大勇, 赵常明, 谢宗强. 神农架世界自然遗产地动物模 式标本名录. 生物多样性, 2017, 25 (5): 513-517.

http://www.biodiversity-science.net/CN/10.17520/biods.2017032

附录1 神农架世界自然遗产地动物模式标本名录

Appendix 1 Checklist of animal type specimens in the Shennongjia World Natural Heritage Site, China

一、真缓步纲 Eutardigrada

缓步动物门 Tardigrada

(一) Parachela 近爪目

1. Hypsibiidae 高生熊虫科

(1) Isohypsibius jinhouensis Yang 金猴等高熊虫

杨潼. 2007. Acta Zootaxonomica Sinica (动物分类学报), 32(1), 186-189. [文献编号: 1, 见附录 2, 下同]. 标本信息 正模: 采集数量和性别不详, 神农架金猴岭, 2005.V. (标本存放地缩写: IH-CAS, 见附录 3, 下同)。

二、少足纲 Pauropoda

节肢动物门 Arthropoda

(二) Tetramerocerata 四少足目

2. Sphaeropauropodidae 球少足科

(2) Sphaeropauropus rotatilis Scheller

Scheller U. 2014. Zootaxa, 3866(3), 301-332. [2].

标本信息 正模: 9우, 湖北神农架自然保护区, 1995.VI.04 (ZML)。

三、蛛形纲 Arachnida

(三) Acaritiformes 真螨目

3. Aturidae 阿土水螨科

(3) Woolastookia megaseta Yi et Jin Yi TC and Jin DC. 2012. International Journal of Acarology, 38(3), 236-243. [3].

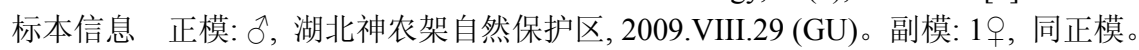

4. Eriophyidae 掼螨科

(4) Abacarus diospyris Kuang et Hong 柿畸瘞螨

匡海源和洪晓月. 1989. Journal of Nanjing Agricultural University (南京农业大学学报), 12(1), 46-49. [4]. 标本信息 正模: ㅇ, 湖北神农架自然保护区, 1986.VII.23 (NAU)。副模: 3 우, 同正模。

(5) Aculops longispinosus Kuang et Hong 长毛刺皮瘘螨

匡海源和洪晓月. 1989. Journal of Nanjing Agricultural University (南京农业大学学报), 12(1), 46-49. [4].

标本信息 正模: ㅇ, 湖北神农架自然保护区, 1986.VII.21 (NAU)。配模: $\partial$, 同正模。副模: 3 우, 同正 模。

(6) Phyllocoptes sorbariae Kuang et Hong 珍珠梅叶刺瘘螨

匡海源和洪晓月. 1989. Journal of Nanjing Agricultural University (南京农业大学学报), 12(1), 46-49. [4]. 标本信息 正模: ㅇ, 湖北神农架自然保护区, 1986.VII.25 (NAU)。配模: 3 , 同正模。副模: 3 우, 同正

模。

5 Phthiracaridae 卷甲螨科

(7) Austrophthiracarus longisetosus Liu et Chen

Liu D and Chen J. 2014. Annales Zoologici, 64(2), 267-272. [5].

标本信息 正模: 1 只, 湖北神农架神农顶, 1998.VI.26 (IZ-CAS)。副模: 1 只，同正模。

6. Trombiculidae 恙螨科

(8) Leptotrombidium (Leptotrombidium) dabashanense Liu et Ma 大巴山纤恙螨

刘井元等. 2001. Acta Zootaxonomica Sinica (动物分类学报), 26(3), 306-312. [6].

标本信息 正模: 1 只, 湖北神农架林区, 1995.IV.24 (HAMS)。副模: 2 只, 同正模。

(四) Parasitiforme 寄螨目

7. Haemogamasidae 血革螨科

(9) Eulaelaps petauristae Liu et Ma 鼠鼠真厉螨 刘井元和马立名. 1998. Acta Zootaxonomica Sinica (动物分类学报), 23(1), 21-24. [7]. 标本信息 正模: + , 湖北神农架林区, 1994.V.06 (AMMS)。副模: 1ㅇ, 同正模 (HAMS)。

(10) Haemogamasus postsinuatus Liu et Ma 后凹血革螨 刘井元和马立名. 2002. Acta Entomologica Sinica (昆虫学报), 45(Suppl.), 118-120. [8]. 标本信息 正模: ㅇ, 湖北神农架自然保护区, 1994.IV. (HAMS)。

(11) Haemogamasus sanxiaensis Liu et Ma 三峡血革螨

刘井元等. 2001. Acta Zootaxonomica Sinica (动物分类学报), 26(3), 306-312. [6]. 标本信息 正模: + , 湖北神农架林区, 1995.V.06 (HAMS)。副模: 3 우, 同正模。 
周友兵, 余小林, 吴楠, 申国珍, 熊高明, 徐文婷, 焚大勇, 赵常明, 谢宗强. 神农架世界自然遗产地动物模 式标本名录. 生物多样性, 2017, 25 (5): 513-517.

http://www.biodiversity-science.net/CN/10.17520/biods.2017032

8. Laelapidae 厉螨科

(12) Androlaelaps subpavlovskii Liu, Ma et Ding 拟巴阳厉螨 刘井元等. 2000. Acta Zootaxonomica Sinica (动物分类学报), 25(4), 380-383. [9].

标本信息 正模: , 湖北神农架林区, 1994.X.04 (HAMS)。副模: 3 우, 同正模; 4우, 湖北神农架林区, 1997.XI.13 (HAMS)。

(13) Cosmolaelaps xiajiangensis Liu et Ma 峡江广厉螨

刘井元等. 2000. Acta Zootaxonomica Sinica (动物分类学报), 25(4), 380-383. [9].

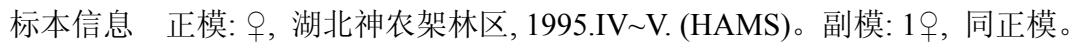

(14) Sinolaelaps liui Liu et Wang 柳氏华厉蜻

刘井元和王敦清. 1997. Acta Zootaxonomica Sinica (动物分类学报), 22(2), 143-146. [10].

标本信息 正模: ㅇ, 湖北神农架林区, 1993.III IV. (AMMS)。副模: 61우, 同正模(AMMS 或 HAMS)。

9. Macrochelidae 巨螯螨科

(15) Macrocheles shennongjiaensis Ma et Liu 神农架巨鳌螨

马立名和刘井元. 2003. Acta Zootaxonomica Sinica (动物分类学报), 28(4), 657-661. [11].

标本信息 正模: ㅇ, 湖北神农架神农顶, 1990.VI.25 (AMMS)。副模: 2우, 同正模。

10. Parasitidae 寄螨科

(16) Amblygamasus shennongjiaensis Ma et Liu 神农架针革螨

马立名和刘井元. 1998. Acta Zootaxonomica Sinica (动物分类学报), 23(3), 267-269. [12].

标本信息 正模: + , 湖北神农架, 1992.IV.18 (HAMS)。

11. Phytoseiidae 植绥螨科

(17) Amblyseius (Amblyseius) subplebeius Wu et Li 拟普通纯绥端

吴伟南和李兆权. 1984. Acta Zootaxonomica Sinica (动物分类学报), 9(1), 44-48. [13].

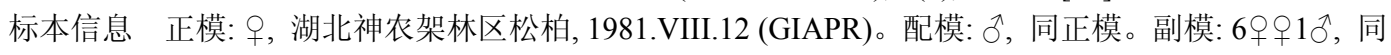
正模; 9우, 湖北神农架林区酒壸坪, 1981.VIII.15 (GIAPR)。

(18) Typhlodromus (Anthoseius) cervix Wu et Li 颈盲走端

吴伟南和李兆权. 1984. Acta Zootaxonomica Sinica (动物分类学报), 9(1), 44-48. [13].

标本信息 正模: +, 湖北神农架林区松柏, 1981.VIII.15 (GIAPR)。副模: 19, 同正模。

(19) Phytoseius (Dubininellus) nudus Wu et Li 光滑植绥峨

吴伟南和李兆权. 1984. Acta Zootaxonomica Sinica (动物分类学报), 9(1), 44-48. [13].

标本信息 正模: ㅇ, 湖北神农架林区松柏, 1981.VIII.18 (GIAPR)。副模: 7우, 同正模; 7우, 湖北神农

架林区酒壸坪, 1981.VIII.22 (GIAPR)。

(20) Phytoseius (Dubininellus) silvaticus Wu et $\mathrm{Li}$ 森林植绥螨

吴伟南和李兆权. 1984. Acta Entomologica Sinica (昆虫学报), 27(1), 457-461. [14].

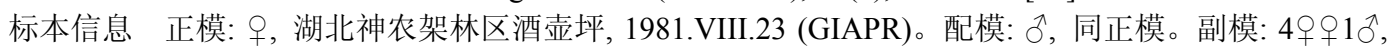

同正模; 2 우，湖北神农架林区松柏, 1981.VIII.15 (GIAPR)。

12. Rhodacaridae 胭螨科

(21) Dendrolaelaps shennongjiaensis Ma et Liu 神农架枝厉螨

马立名等. 2003. Acta Zootaxonomica Sinica (动物分类学报), 28(2), 252-255. [15].

标本信息 正模: + , 湖北神农架, 1999.VIII.16 (HAMS)。

(五) Araneae 蜘蛛目

13. Agelenidae 漏斗蛛科

(22) Cicurina eburnus Wang 象牙蟋蛛

王家福. 1994. Acta Zootaxonomica Sinica (动物分类学报), 19(3), 286-292. [16].

标本信息 正模: ㅇ, 湖北省大巴山木鱼坪, 1990.XI.10 (HNAAS)。配模: §, 同正模。副模: 1，同正模。

(23) Tonsilla eburniformis Wang et Yin 象牙形扁桃蛛

王家福和尹长民. 1992. Journal of Natural Science of Hunan Normal University (湖南师范大学自然科学学

报), 15(3), 263-266, 272. [17].

标本信息 正模: 早, 湖北神农架木鱼镇, 1990.XI.12 (HNAAS)。

14. Amaubobiidae 暗蛛科

(24) Coelotes calcariformis Wang 距形隙蛛

王家福. 1994. Acta Zootaxonomica Sinica (动物分类学报), 19(3), 286-292. [16].

标本信息 正模: ㅇ, 湖北省大巴山, 1990.XI.10 (HNAAS)。配模: §, 同正模。副模: 1ㅇ, 同正模。

(25) Coelotes multannulatus Zhang, Zhu, Sun et Song 多环隙蛛

张志升等. 2006. Journal of Dali University (大理学院学报), 5(2), 1-3, 36. [18].

标本信息 正模: 9 , 湖北神农架木鱼镇, 2001.IX.23 (HU)。副模: 1ㅇ, 同正模; 2 + , 湖北神农架木鱼至神 
周友兵, 余小林, 吴楠, 申国珍, 熊高明, 徐文婷, 焚大勇, 赵常明, 谢宗强. 神农架世界自然遗产地动物模 式标本名录. 生物多样性, 2017, 25 (5): 513-517.

http://www.biodiversity-science.net/CN/10.17520/biods.2017032

农坛, 2004.IX.3 (HU)。

(26) Coelotes pedodentalis Zhang, Zhu, Sun et Song 足齿隙蛛

张志升等. 2006. Journal of Dali University (大理学院学报), 5(2), 1-3, 36. [18].

标本信息 正模: 9 , 湖北神农架木鱼至神农坛, 2004.IX.3 (HU)。

(27) Coelotes vestigialis Xu et $\mathrm{Li}$ 痕迹隙蛛

徐湘和李枢强. 2007. Acta Zootaxonomica Sinica (动物分类学报), 32(4), 756-757. [19].

标本信息 正模: §, 湖北神农架自然保护区酒壸坪, 1998.VII.24 VIII.8 (IZ-CAS)。副模: 10ðð, 同正模。

(28) Draconarius colubrinus Zhang, Zhu et Song 蛇突龙隙蛛

张志升等. 2002. Journal of Baoding Teachers College (保定师范专科学校学报), 15(2), 52-54. [20].

标本信息 正模: §, 湖北神农架木鱼镇, 2001.IX.22 (HU)。副模: $39+$, 同正模。

(29) Draconarius parawudangensis Zhang, Zhu et Song 拟武当龙隙蛛

张志升等. 2002. Journal of Baoding Teachers College (保定师范专科学校学报), 15(2), 52-54. [20].

标本信息 正模: ㅇ, 湖北神农架, 2001.IX.22 IX.24 (HU)。副模: 5 우, 同正模。

(30) Paracoelotes xinping Zhang, Zhu et Song 新平拟隙蛛

张志升. 2002. Journal of Baoding Teachers College (保定师范专科学校学报), 15(2), 52-54. [20].

标本信息 正模: §, 湖北神农架木鱼镇, 2001.IX.22 (HU)。副模: $1 \precsim 3$ 우, 同正模。

15. Clubionidae 管巢蛛科

(31) Clubiona flexa Zhang et Chen 曲管巢蛛

张古忍和陈建. 1993. Acta Zootaxonomica Sinica (动物分类学报), 18(3), 306-308. [21].

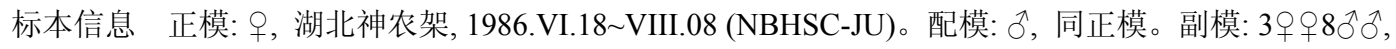

同正模。

16. Linyphiidae 皿蛛科

(32) Aprifrontalia afflata Ma et Zhu 膨大吻额蛛

马晓丽和朱传典. 1991. Acta Zootaxonomica Sinica (动物分类学报), 16(2), 169-171. [22].

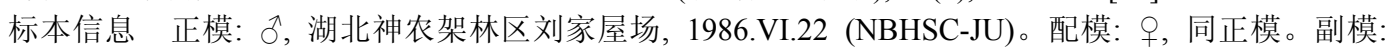

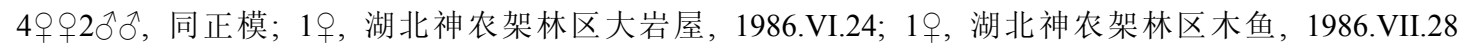
(NBHSC-JU)。

(33) Asperthorax granularis Gao et Zhu 粒突皱胸蛛

高久春和朱传典. 1989. Journal of Norman Bethune University of Medical Science (白求恩医科大学学报), 15(3), 246-247. [23].

标本信息 正模: 9, 湖北神农架林区酒壶林场, 1986.VI.22 (NBHSC-JU)。副模: 3 우, 同正模。

(34) Gnathonarium phragmigerum Gao et Zhu 中隔额角蛛

高久春和朱传典. 1988. Acta Zootaxonomica Sinica (动物分类学报), 13(4), 350-352. [24].

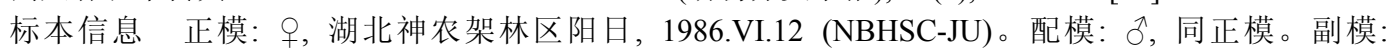

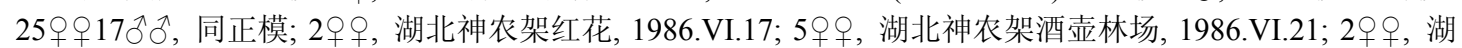

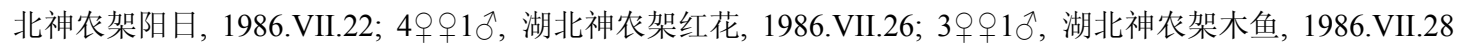
(NBHSC-JU)。

(35) Hypselistes acutidens Gao, Sha et Zhu 舟齿闪腹蛛

高久春等. 1989. Acta Zootaxonomica Sinica (动物分类学报), 14(4), 424-426. [25].

标本信息 正模: 9 , 湖北神农架林区大岩屋, 1986.VI.23 (NBHSC-JU)。配模: $\widehat{\partial}$, 同正模。副模: 3 9 9 , 同 正模; 2ㅇ, 湖北神农架大岩屋, 1986.VI.24; 39 平, 湖北神农架大九湖, 1986.VIII.09 (NBHSC-JU)

(36) Lepthyphantes ancatus Li et Zhu 垂耳斑血蛛

李枢强和朱传典. 1989. Journal of Norman Bethune University of Medical Science (白求恩医科大学学报), 15(1), 38-39. [26].

标本信息 正模: 9 , 湖北神农架林区刘家屋场, 1986.VI.22 (NBHSC-JU)。副模: 4우, 同正模。

(37) Lepthyphantes halonatus Li et Zhu 月晕斑皿蛛

李枢强和朱传典. 1995. Acta Zootaxonomica Sinica (动物分类学报), 20(1), 39-48. [27].

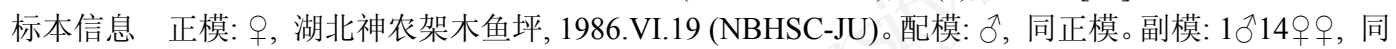

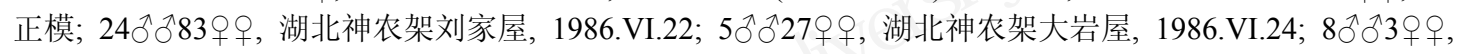
湖北神农架徐家庄, 1986.VIII.15; $3 \widehat{\partial} 12$ 우, 湖北神农架大九湖, 1986.VIII.08 (NBHSC-JU)。

(38) Macrargus alpinus Li et Zhu 山地珍蛛

李枢强和朱传典. 1995. Acta Zootaxonomica Sinica (动物分类学报), 20(1), 39-48. [27].

标本信息 正模: §, 湖北神农架盘龙, 1986.VI.26 (NBHSC-JU)。配模: 9 , 同正模。副模: $8 \lesssim \Uparrow 15$ 우, 同 正模; 7우오, 贵州黑湾河, 1985.VI.23 (NBHSC-JU)。

(39) Mecopisthes rhomboidalis Gao, Zhu et Gao 梭形额突蛛 
周友兵, 余小林, 吴楠, 申国珍, 熊高明, 徐文婷, 焚大勇, 赵常明, 谢宗强. 神农架世界自然遗产地动物模 式标本名录. 生物多样性, 2017, 25 (5): 513-517.

http://www.biodiversity-science.net/CN/10.17520/biods.2017032

高久春等. 1993. Journal of Norman Bethune University of Medical Science (白求恩医科大学学报), 19(1), 40-42. [28].

标本信息 正模: 9 , 湖北神农架林区木鱼, 1986.VI.19 (NBHSC-JU)。副模: 12 + 9 , 湖北神农架木鱼、宋 洛、红花、酒売、红坪、徐家庄, 1986.VI.19 1986.VII.17 (NBHSC-JU)。

(40) Meioneta falcata Li et Zhu 镰蛛儒蛛

李枢强和朱传典. 1995. Acta Zootaxonomica Sinica (动物分类学报), 20(1), 39-48. [27].

标本信息 正模：，湖北神农架刘家屋，1986.VI.20 VII.30 (NBHSC-JU)。配模：〕，同正模。副

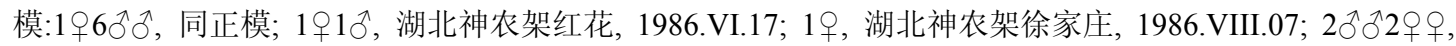
湖北神农架大九湖, 1986.VIII.9; $4 \precsim 3$ 우우, 湖北神农架板仓, 1986.VIII.10 (NBHSC-JU)。

(41) Meioneta palustris Li et Zhu 沼泽侏儒蛛

李枢强和朱传典. 1995. Acta Zootaxonomica Sinica (动物分类学报), 20(1), 39-48. [27].

标本信息 正模: +, 湖北神农架大九湖, 1986.VIII.09 (NBHSC-JU)。副模: 3 우, 同正模。

(42) Neriene aquilirostralis Chen et Zhu 鹰味盖蛛

陈建和朱传典. 1989. Acta Zootaxonomica Sinica (动物分类学报), 14(2), 160-165. [29].

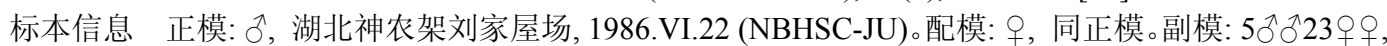
采集地点同正模, 1986.VI.20 VI.22; 4우1 0 , 湖北神农架大岩屋, 1986.VI.23; 1 9 , 湖北神农架刘家屋场, 1986.VII.30; 8 우, 湖北神农架红坪, 1986.VII.30 VIII.01; 2 우 13 , 湖北神农架徐家庄, 1986.VIII.16; 1ㅇ, 湖 北神农架阳日湾, 1986.VIII.18 (NBHSC-JU)。

(43) Neriene calozonata Chen et Zhu 丽带盖蛛

陈建和朱传典. 1989. Acta Zootaxonomica Sinica (动物分类学报), 14(2), 160-165. [29].

标本信息 正模: 우 湖北省燕洞, 1986.VIII.07 (NBHSC-JU)。副模: 2 우，同正模。

(44) Neriene decormaculata Chen et Zhu 华斑盖蛛

陈建和朱传典. 1988. Acta Zootaxonomica Sinica (动物分类学报), 13(4), 346-349. [30].

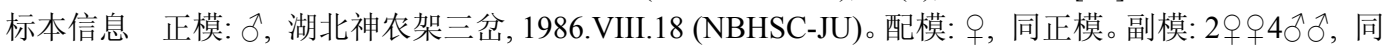

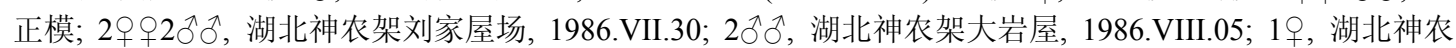
架大九湖, 1986.VIII.9 (NBHSC-JU)。

(45) Oedothorax collinus Ma et Zhu 毛丘瘤胸蛛

马晓丽和朱传典. 1991. Acta Zootaxonomica Sinica (动物分类学报), 16(1), 27-29. [31].

标本信息 正模: §, 湖北神农架林区大岩屋, 1986.VI.23 (NBHSC-JU)。配模: 우 , 同正模。副模: $1 \lesssim 4$ 우, 同正模; 1ㅇ, 湖北神农架林区红坪, 1986.VIII.01 (NBHSC-JU)。

(46) Oedothorax foratus Ma et Zhu 穿孔瘤胸蛛

马晓丽和朱传典. 1990. Acta Zootaxonomica Sinica (动物分类学报), 15(4), 431-435. [32].

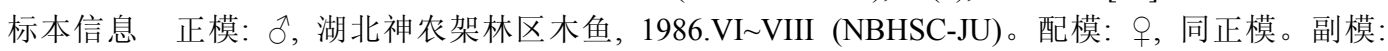
14 우 $10 \widehat{\jmath}$ 今, 同正模。

(47) Oedothorax rimatus Ma et Zhu 裂缝瘤脚蛛

马晓丽和朱传典. 1990. Acta Zootaxonomica Sinica (动物分类学报), 15(4), 431-435. [32].

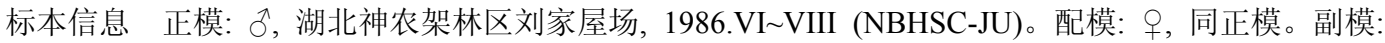
10 우 $13 \hat{\jmath}$ ऽ, 同正模。

(48) Parameioneta bilobata Li et Zhu 二叶玲蛛

李枢强和朱传典. 1995. Acta Zootaxonomica Sinica (动物分类学报), 20(1), 39-48. [27].

标本信息 正模：ふ，湖北神农架林区刘家屋场，采集时间不详 (NBHSC-JU)。配模o，同正模。副模:

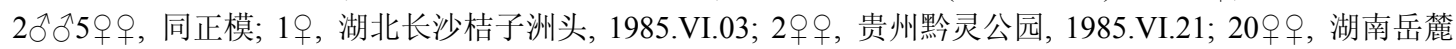
山 1985.VI.03 VI.11 (NBHSC-JU)。

17. Nemesiidae 线蛛科

(49) Raveniola spirula Li et Zonstein

Li SQ and Zonstein S. 2015. ZooKeys, 519, 1-32. [33].

标本信息 正模: §, 湖北神农架官门山, 1998.VII.23 VII.30 (IZ-CAS)。副模: 22ふðへ, 同正模。

18. Sparassidae 巨蟹蛛科

(50) Sinopoda angulata Jäger, Gao et Fei

Jäger P et al. 2002. Acta Arachnologica, 51(1), 23-31. [34].

标本信息 正模: 古, 湖北神农架刘家屋, 1986.VII.29 (JU)。

(51) Sinopoda shennonga Peng, Yin et Kim

Peng XJ et al. 1996. Korean Arachnology, 12 (1), 57-61. [35].

标本信息 正模: 今。, 湖北神农架襄阳县, 1990.X (HNU)。

四、昆虫纲 Insecta 
周友兵, 余小林, 吴楠, 申国珍, 熊高明, 徐文婷, 焚大勇, 赵常明, 谢宗强. 神农架世界自然遗产地动物模 式标本名录. 生物多样性, 2017, 25 (5): 513-517.

http://www.biodiversity-science.net/CN/10.17520/biods.2017032

(六) Protura 原尾目

19. Berberentomidae 檗蚖科

(52) Kenyentulus hubeinicus Yin 湖北肯蚖 尹文英. 1987. Entomotaxonomia (昆虫分类学报), 9(1), 77-84. [36]. 标本信息 全模: 1ㅇ, 湖北神农架泮水, 1983.VII.30 (SEM); 1ㅇ, 湖北神农架松柏, 1983.VIII.8 (SEM)。

(53) Kenyentulus shennongjiensis Yin 神农架肯蚖 尹文英. 1987. Entomotaxonomia (昆虫分类学报), 9(1), 77-84. [36].

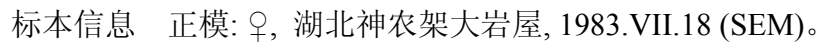

(54) Kenyentulus xingshanensis Yin 兴山肯蚖 尹文英. 1987. Entomotaxonomia (昆虫分类学报), 9(1), 77-84. [36]. 标本信息 正模: 古, 湖北神农架大岩屋, 1983.VII.20 (SEM)。

(七) Odonata 蜻蜓目

20. Aeshnidae 蜓科

(55) Aeshna shennong Zhang et Cai 神农蜓 Zhang HM \& Cai QH. 2014. Zootaxa, 3795 (4), 489-493. [37].

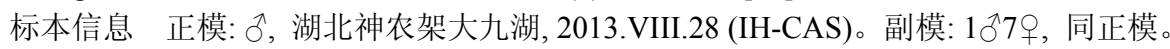

(56) Cephalaeschna discolor Zhang, Cai et Liao 异色头蜓 Zhang HM et al. 2013. International Journal of Odonatology, 16(2), 157-176. [38].

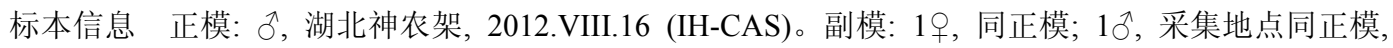
2012.IX.16; $2 \hat{\jmath}$, 采集地点同正模, 2012.VIII.08 (IH-CAS)。

(57) Cephalaeschna mattii Zhang, Cai et Liao 马蒂头蜓 Zhang HM et al. 2013. International Journal of Odonatology, 16(2), 157-176. [38].

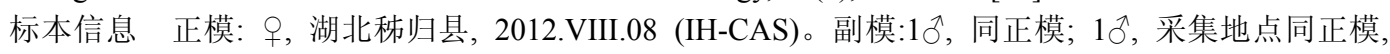

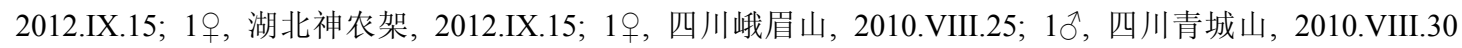
(IH-CAS)。

(58) Cephalaeschna solitaria Zhang, Cai et Liao 独行头蜓 Zhang HM et al. 2013. International Journal of Odonatology, 16(2), 157-176. [38].

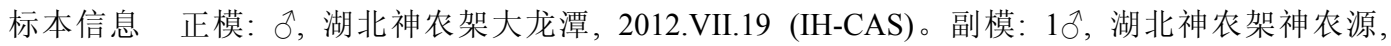
2012.VII.19 (IH-CAS)。

21. Corduliidae 伪蜻科

(59) Somatochlora shennong Zhang, Vogt et Cai 神农架金光伪蜻 Zhang HM et al. 2014. Zootaxa, 3878 (5), 479-484. [39]. 标本信息 正模: §, 湖北神农架自然保护区大九湖, 2012.VIII.09 (IH-CAS)。副模: 11ðð3우 同正模;

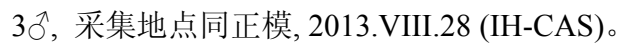

(八) Plecoptera 襀翅目

22. Leuctridae 卷襀科

(60) Rhopalopsole sinensis Yang et Yang 中华诺襀 杨定和杨集昆. 1993. Entomotaxononmia (昆虫分类学报), 15(4), 235-238. [40].

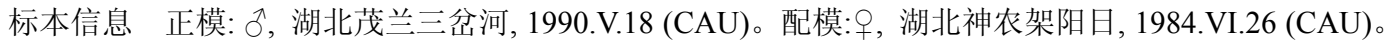

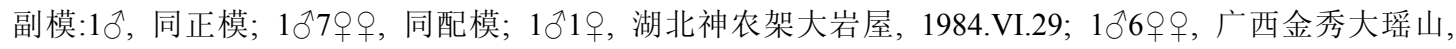
1982.VI.11 (CAU)。

(61) Rhopalopsole hongpingana Sivec et Harper Sivec I et al. 2008. Scopolia, 64, 1-122. [41]. 标本信息 正模: ठ, 湖北神农架红坪, 1997.VII.19(YU)。

(62) Rhopalopsole memorabilis Qian et Du Qian YH et al. 2014. Florida Entomologist, 97(2), 605-610. [42].

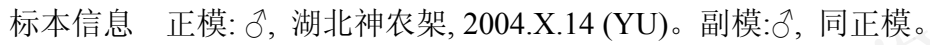

(63) Rhopalopsole apicispina Yang et Yang 双刺诺蜻 杨定和杨集昆. 1991. Journal of Hubei University (Natural Science) (湖北大学学报(自然科学版)), 13(4), 369-372. [43].

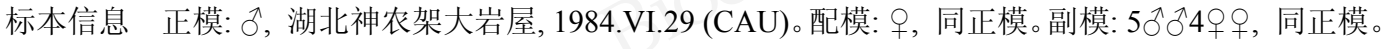

(九) Orthoptera 直翅目

23. Catantopidae 斑腿蝗科

(64) Caryanda badongensis Wang 巴东卵翅蝗

王裕文. 1995. Acta Zootaxonomica Sinica (动物分类学报), 20(1), 81-85. [44]. 
周友兵，余小林，吴楠，申国珍，熊高明，徐文婷，樊大勇，赵常明，谢宗强. 神农架世界自然遗产地动物模 式标本名录. 生物多样性, 2017, 25 (5): 513-517.

http://www.biodiversity-science.net/CN/10.17520/biods.2017032

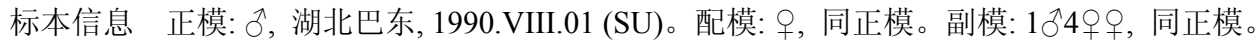

24. Eumastacidae 蜢科

(65) Pielomastax obtusidentata Zheng 钝齿比蜢

郑哲民. 1997. Entomotaxonomia (昆虫分类学报), 19(1), 13-16. [45].

标本信息 正模: 옹 湖北神农架松柏, 1995.VII.02 (SNU)。副模: 1우 , 同正模。

(66) Pielomastax shennongjaensis Wang 神农架比蜢

王裕文. 1995. Acta Zootaxonomica Sinica (动物分类学报), 20(2), 204-206. [46].

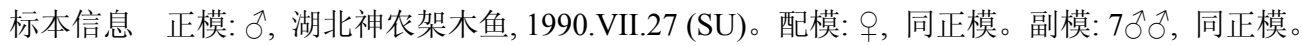

(67) Pielomastax tenuicerca Hsia et Liu 细尾比蜢

夏凯龄和刘宪伟. 1989. Entomotaxonomia (昆虫分类学报), 11(4), 253-258. [47].

标本信息 正模: $\curvearrowright$, 湖北神农架盘水, 1983.VII.30 (SEM)。配模: 우, 同正模。副模: 4우, 同正模。

25. Phaneropteridae 露虫科

(68) Bulbistridulous dentatus Chang et Zheng 齿尾鼓鸣虫

常岩林和郑哲民. 1997. Entomotaxonomia (昆虫分类学报), 19(1), 10-12. [48].

标本信息 正模: §, 湖北神农架, 1995.VIII.03 (SNU)。

(69) Shennongia inermis Liu 无刺神农蚉

杨星科主编. 1997. In: Insects of the Three Gorge reservoir area of Yangtze River (长江三峡库区昆虫), pp. 147. [49].

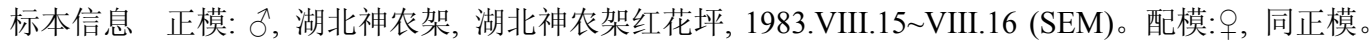
副模:2우, 四川巫山梨子坪, 1994. IX.21 IX.212 (IZ-CAS)。

(70) Shirakisotima acuminate Wang et Liu 尖叶素木蚉

王裕文和刘宪伟. 1996. Journal of Shandong University (Natural Science) (山东大学学报(自然科学版)),

31(3), 336-340. [50].

标本信息 正模: 今゙, 湖北巴东, 1990.VII.31 (SEM 或 SU)。

26. Rhaphidophoridae 驼虫科

(71) Diestrammena (Gymnaeta) semicrenata Gorochov, Rampini et Di Russo 拟裸灶蚉 Gorochov AV et al. 2006. Russian Entomological Journal, 15(4), 355-360. [51].

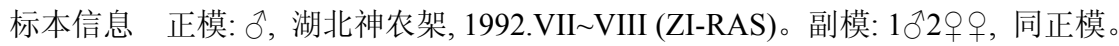

27. Tetrigidae 虾科

(72) Formosatettix hubeiensis Zheng, Li et Wei 湖北台蚱

郑哲民等. 2002. Acta Entomologica Sinica (昆虫学报), 45(5), 644-647. [52].

标本信息 正模: §, 湖北神农架红花朵, 1999.VIII.10 (SNU)。副模: $1 \delta$, 同正模。

(73) Formosatettix shennongjiaensis Zheng 神农架台蚱

杨星科主编. 1997. In: Insects of the Three Gorge reservoir area of Yangtze River (长江三峡库区昆虫), pp.

141. [49].

标本信息 正模: 古, 湖北神农架香溪源, 1994.V.05 (IZ-CAS)。配模: 今, 同正模。

(74) Tetrix lativertex Zheng, Li et Wei 宽顶蚱

郑哲民等. 2002. Acta Entomologica Sinica (昆虫学报), 45(5), 644-647. [52].

标本信息 正模: 우 副模: 2 우, 湖北神农架红花朵, 1999.VIII.10 (SNU)。

(75) Tetrix shennongjiaensis Zheng, Li et Wei 神农架蚱

郑哲民等. 2002. Acta Entomologica Sinica (昆虫学报), 45(5), 644-647. [52].

标本信息 正模: 芉, 湖北神农架松柏, 1999.VIII.09 (SNU)。

(十) Anoplura 虫目

28. Hystrichopsyllidae 多毛蚤科

(76) Rhadinopsylla (Actenophthalmus) blconcava Chen, Ji et Wu 双凹纤蚤 陈家贤等. 1984. Acta Zootaxonomica Sinica (动物分类学报), 9(1), 82-84. [53].

标本信息 正模: ○, 湖北神农架, 1960.V (ACDPC 或 AMMS 或 CAMS)。配模 + , 湖北神农架, 1960.VI.29 (ACDPC 或 AMMS 或 CAMS)。副模 1ð2웅, 湖北神农架, 1960.VI.29 VI.23; 1今, 四川南坪县, 1979.VI.27; $3 \hat{\jmath} 4$ 우, 四川黑水县, 1980.VIII IX (ACDPC 或 AMMS 或 CAMS)。

(十一) Thysanoptera 纱翅目

29. Thripidae 蓟马科

(77) Helionothrips shennongjiaensis Feng, Yang et Yang 神农架领针蓟马 冯纪年等. 2007. Acta Zootaxonomica Sinica (动物分类学报), 32(2), 451-454. [54].

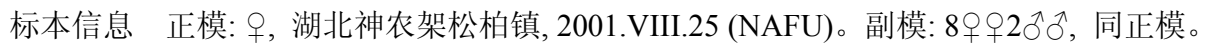

(78) Vulgatothrips shennongjiaensis Han 神农架普通蓟马 
周友兵, 余小林, 吴楠, 申国珍, 熊高明, 徐文婷, 焚大勇, 赵常明, 谢宗强. 神农架世界自然遗产地动物模 式标本名录. 生物多样性, 2017, 25 (5): 513-517.

http://www.biodiversity-science.net/CN/10.17520/biods.2017032

杨星科主编. 1997. In: Insects of the Three Gorge reservoir area of Yangtze River (长江三峡库区昆虫), pp.

544. [49].

标本信息 正模: + , 湖北兴山龙门河, 1994.V.06 (IZ-CAS)。副模: 1ㅇ, 湖北神农架, 1994.V.05; 1 9 , 四川 巫山梨子坪, 1994.V.19 (IZ-CAS)。

(十二) Homoptera 同翅目

30. Cicadellidae 叶蝉科

(79) Bundera trimaculata Li et Yang 三斑斜脊叶蝉

李子忠等. 2002. Acta Zootomologica Sinica (动物分类学报), 27(3), 548-555. [55].

标本信息 正模: $\curvearrowright$, 湖北神农架, 1998.VIII.04 (NAFU 或 GU 或 IZ-CAS)。副模: $1 \curvearrowright$, 同正模。

(80) Balala curvata Shen et Zhang 弯突片胫杆蝉

沈林和张雅林. 1995. Entomotaxonomia (昆虫分类学报), 17(4), 271-274. [56].

标本信息 正模: 今, 湖北神农架红花公社, 1980.VII.24 (IZ-CAS)。

(81) Erecticornia brunneimarginata Yuan et Xu 褐缘坚角蝉

袁锋等. 1997. Entomotaxonomia (昆虫分类学报), 19(3), 185-190. [57].

标本信息 正模: 9 , 湖北神农架, 1977.VI.28 (NAFU)。

31. Aphrophoridae 尖胸沫蝉科

(82) Sinophora shennongjiensis Chou et Yuan 神农华沫蝉

周尧等. 1986. Entomotaxonomia (昆虫分类学报), 8(1, 2), 97-111. [58].

标本信息 正模: §, 湖北神农架酒壶, 1980.VIII.29 (NAFU)。配模: + , 采集地点同正模, 980.VII.24 (NAFU)。副模: 7ふふぇ, 同正模。

32. Margarodidae 绵蚧科

(83) Matsucoccus shennongjiaensis Yong et $\mathrm{Lu}$ 神农架松干蚧

杨平澜. 1986. Contr. Shanghai: Inst. Entomol (昆虫学研究集刊), 6, 195-198. [59].

标本信息 正模: 性别和数量不详, 湖北神农架, 1986.VII. (SEM)。配模: 性别和数量不详, 湖北神农架, 1986.VII. (HEVC)。

(十三) Hemiptera 半翅目

33. Acanthosomatidae 同蝽科

(84) Acanthosoma acutangulata Liu 漆刺肩同蝽

刘胜利. 1979. Entomotaxononmia (昆虫分类学报), 1(1), 55-59. [60].

标本信息 正模: ふ, 湖北神农架松柏, 1977.VI.22 (TNMH)。配模: +, 同正模。副模: §, 同正模。

(85) Elasmucha laeviventris Liu 光腹匙同蝽

刘胜利. 1979. Entomotaxononmia (昆虫分类学报), 1(1), 55-59. [60].

标本信息 正模: §, 湖北神农架大九湖, 1977.VI.10 (TNMH)。配模: + , 同正模。副模: $20 \lesssim ð 24 ㅇ$, 湖 北神农架, 采集时间不详 (TNMH)。

34. Aradidae 扁蝽科

(86) Aneurus hubeiensis Liu 鄂无脉扁蝽

刘胜利. 1981. Acta Entomologica Sinica (昆虫学报), 24(2), 184-187. [61].

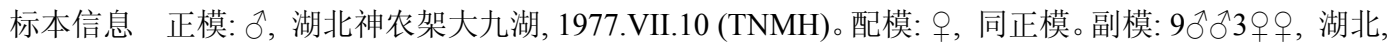
采集时间不详 (TNMH)。

(87) Usingerida hubeiensis Liu 湖北尤扁蝽

刘胜利. 1980. Acta Zootomologica Sinica (动物分类学报), 5(2), 175-184. [62].

标本信息 正模: , 湖北神农架红坪, 1977.VI.29 (TNMH)。

(88) Wuiessa spinosa Liu 刺颊胡扁蝽

刘胜利. 1980. Acta Zootomologica Sinica (动物分类学报), 5(2), 175-184. [62].

标本信息 正模: $\circlearrowright$, 湖北神农架红坪, 1977.VII.01 (TNMH)。配模: + , 同正模。副模: $1 \lesssim 2$ 우，同正模。

35. Cicadellidae 叶蝉科

(89) Onukigallia tumida Li, Dai et $\mathrm{Li}$

Li et al. 2016. ZooKeys, 622, 85-93. [63].

标本信息 正模: §, 湖北神农架, 2013.VII.17 (GU)。副模 1ठ̋, 湖南八大公山, 2013.VIII.03 (GU)。

36. Lygaeidae 长蝽科

(90) Emphanisis hubeiensis Zou et Zheng 湖北古铜长蝽

邹环光和郑乐怡. 1980. Acta Zootaxonomica Sinica (动物分类学报), 5(4), 404-408. [64].

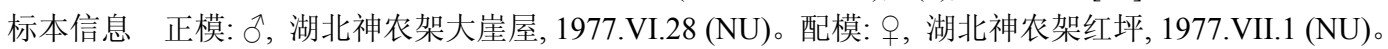

副模: $2 \lesssim \precsim$, 同配模。

37. Miridae 盲蝽科 
周友兵, 余小林, 吴楠, 申国珍, 熊高明, 徐文婷, 焚大勇, 赵常明, 谢宗强. 神农架世界自然遗产地动物模 式标本名录. 生物多样性, 2017, 25 (5): 513-517.

http://www.biodiversity-science.net/CN/10.17520/biods.2017032

(91) Arbolygus longustus Lu et Zheng 狭长树丽盲蝽

吕楠和郑乐怡. 1998. Entomotaxononmia (昆虫分类学报), 20(2), 79-96. [65].

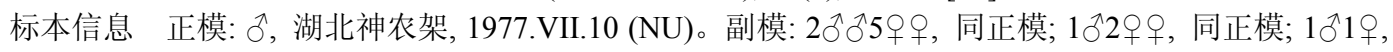
采集地点同正模, 1977.VII.09 (NU)。

(92) Lygus (Apolygus) ornatus Zheng et Wang 斑丽盲蝽 郑乐怡和汪兴鉴. 1983. Acta Zootaxonomica Sinica (动物分类学报), 8(4), 422-429. [66]. 标本信息 正模: §, 湖北神农架大九湖, 1977.VII.10 (NU)。配模: + , 同正模。副模: $4 \lesssim \precsim 10$ 우, 同正模。

38. Pentatomidae 蝽科

(93) Plautia propinqua Liu et Zheng 邻珀蝽

刘强和郑乐怡. 1994. Entomotaxonomia (昆虫分类学报), 16(4), 235-248. [67].

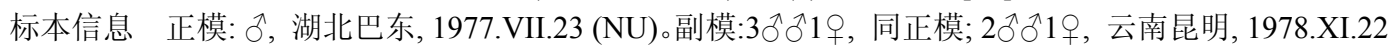

(NU); 1 ठ1우 甘肃文县范坝, 1988.VII.30 (NU)。

(十四) Neuroptera 脉翅目

39. Chrysopidae 草蛉科

(94) Chrysopidia shennongana Yang et Wang 神农三阶草蛉

杨集昆和王象贤. 1990. 湖北大学学报(自然科学版), 12(2), 154-163. [68].

标本信息 正模: +, 湖北神农架松柏镇, 1984.VI.23 (CAU)。

(95) Chrysopidia sinica Yang et Wang 中华三阶草蛉

杨集昆和王象贤. 1990. 湖北大学学报(自然科学版), 12(2), 154-163. [68].

标本信息 正模: $§$, 湖北神农架大岩屋, 1984.VI.02 (CAU)。配模: + , 同正模。副模: 2 , 同正模; $2 \hat{\jmath}$,

甘肃文县高楼山, 1980.VIII.01 (CAU)。

(96) Chrysopidia zhaoi Yang et Wang 赵氏三阶草蛉

杨集昆和王象贤. 1990. 湖北大学学报(自然科学版), 12(2), 154-163. [68].

标本信息 正模: P, 湖北神农架松柏镇, 1984.VI.24 (CAU)。

(97) Navasius vitticlypeus Yang et Wang 唇斑纳草蛉

杨集昆和王象贤. 1990. 湖北大学学报(自然科学版), 12(2), 154-163. [68].

标本信息 正模: 今, 湖北神农架大岩屋, 1984.VI.02 (CAU)。

(98) Tjederina exiana Yang et Wang 鄂西替草蛉

杨集昆和王象贤. 1990. 湖北大学学报(自然科学版), 12(2), 154-163. [68].

标本信息 正模: $\widehat{0}$, 湖北神农架松柏镇, 1984.VI.23 (CAU)。配模: 9 , 同正模。副模:3우, 采集地点同正

模, 1984.VI.24; 19, 湖北房县桥上, 1977.VI.17 (CAU)。

40. Hemerobiidae 褐蛉科

(99) Hemerobius atrocorpus Yang 黑体褐蛉

杨星科主编. 1997. In: Insects of the Three Gorge reservoir area of Yangtze River (长江三峡库区昆虫), pp. 589. [49].

标本信息 正模: 今, 湖北神农架, 1977.VII.06 (CAU 或 IZ-CAS)。

(100) Sineuronema angusticolla Yang 细颈华脉线蛉

杨星科主编. 1997. In: Insects of the Three Gorge reservoir area of Yangtze River (长江三峡库区昆虫), pp.

586. [49].

标本信息 正模: 早，湖北神农架酒売, 1980.VIII.29 (CAU 或 IZ-CAS)。

41. Myrmeleontidae 蚁蛉科

(101) Asialeon validum Yang 强亚蚁蛉

杨星科主编. 1997. In: Insects of the Three Gorge reservoir area of Yangtze River (长江三峡库区昆虫), pp. 614. [49].

标本信息 正模: 9 , 湖北神农架松柏镇, 1980.VII.18 (CAU 或 IZ-CAS)。副模: 4 9 , 湖北兴山县龙门河, 1993.VII.16 VII.18 (CAU 或 IZ-CAS)。

(102) Dendroleon decorillus Yang 小华树蚁蛉

杨星科主编. 1997. In: Insects of the Three Gorge reservoir area of Yangtze River (长江三峡库区昆虫), pp. 615. [49].

标本信息 正模: §, 湖北神农架大酒壶 (大九湖), 1977.VII.09 (CAU 或 IZ-CAS)。

42. Osmylidae 溪蛉科

(103) Heterosmylus shennonganus Yang 神农异溪蛉

杨星科主编. 1997. In: Insects of the Three Gorge reservoir area of Yangtze River (长江三峡库区昆虫), pp. 581. [49].

标本信息 正模: §, 湖北神农架大崖屋, 1985.VIII.21 (CAU)。配模: †, 同正模。副模: $4 \lesssim \precsim 1$, 同正模。 
周友兵, 余小林, 吴楠, 申国珍, 熊高明, 徐文婷, 焚大勇, 赵常明, 谢宗强. 神农架世界自然遗产地动物模 式标本名录. 生物多样性, 2017, 25 (5): 513-517.

http://www.biodiversity-science.net/CN/10.17520/biods.2017032

(104) Lysmus victus Yang 胜利离溪蛉

杨星科主编. 1997. In: Insects of the Three Gorge reservoir area of Yangtze River (长江三峡库区昆虫), pp. 581. [49].

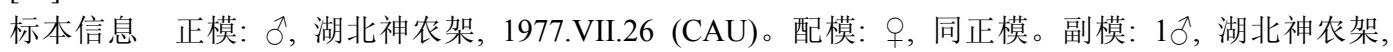
1977.VII.22 (CAU); $3 \delta^{\Uparrow} 1$ \% , 湖北兴山县龙门河, 1993.VII.15 (CAU)。

(105) Osmylus fuberosus Yang 偶瘤溪蛉

杨星科主编. 1997. In: Insects of the Three Gorge reservoir area of Yangtze River (长江三峡库区昆虫), pp. 580. [49].

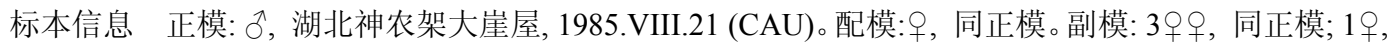
湖北神农架酒壸, 1986.VII.29; 19, 竹溪县泉溪, 1983.IX.12; 19, 湖北兴山县龙门河, 1994.IX.13 (CAU)。

(十五) Coleoptera 鞘翅目

43. Cantharidae 花萤科

(106) Lycocerus hubeiensis Yang et Yang

Yang et al. 2014. ZooKeys, 456, 85-107. [69].

标本信息 正模: $\delta$, 湖北大老岭, 2011.VII.09 (HU 或 IZ-CAS)。副模:1 + , 同正模; 1 9 , 采集地点同正模, 2011.VII.10；10，湖北大巴东绿葱坡, 2006.VII.18; 19, 湖北巴东天三坪, 2006.VII.14; 19, 湖北神农架八角 庙, 2003.VII.17; 19, 相同采集地点, 2003.VII.19; 1万, 湖北神农架温水森林, 2003.VII.20; 19, 湖北兴山龙门 河, 1993.VI.15; 1ㅇ, 采集地点同上, 1993.VII.18; 1ㅇ, 采集地点同上, 1993.VII.22 VII.23; 1ㅇ, 湖北五峰后河, 2002.VII.21 (HU 或 IZ-CAS)。

44. Carabidae 步甲科

(107) Pterostichus (Circinatus) yan Shi et Liang 炎通缘步甲

Shi HL and Liang HB. 2015. ZooKeys, 536, 1-92. [70].

标本信息 正模: ふ, 湖北神农架木鱼, 1997.VI.12 VI.15 (NMB)。

(108) Pterostichus (Morphohaptoderus) dentellus Facchini et Sciaky

Facchini S. and Sciaky R. 2003. Koleopterologische Rundschau, 73, 7-17. [71].

标本信息 正模: $\delta$, 湖北神农架, 1995.VI.08 (CFP 或 CSM 或 CWB 或 NMW)。副模: 7ð̊우, 同正模;

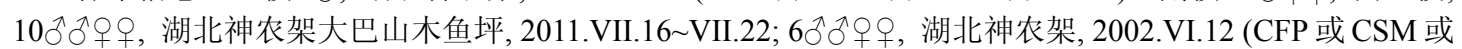
CWB 或 NMW)。

(109) Pterostichus (Morphohaptoderus) hubeicus Facchini et Sciaky

Facchini S. and Sciaky R. 2003. Koleopterologische Rundschau, 73, 7-17. [71].

标本信息 正模: §, 湖北神农架, 1995.VI.28 VII.03 (CFP 或 CSM 或 CWB); 副模: 19, 同正模; $5 \AA \widehat{\jmath}$ 우, 湖北神农架大巴山木鱼坪, 2001.VII.16 VII.22 (CFP 或 CSM 或 CWB)。

(110) Pterostichus (Morphohaptoderus) shennongjianus Facchini et Sciaky

Facchini S. and Sciaky R. 2003. Koleopterologische Rundschau, 73, 7-17. [71].

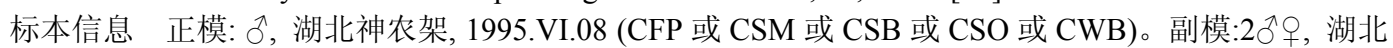

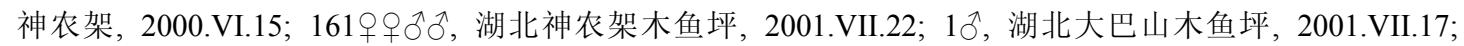

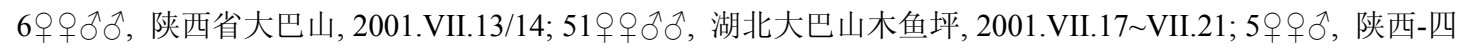
川交界处大巴山, 2001.VII.12 (CFP 或 CSM 或 CSB 或 CSO 或 CWB)。

(111) Pterostichus (Morphohaptoderus) toledanoi Facchini et Sciaky

Facchini S. and Sciaky R. 2003. Koleopterologische Rundschau, 73, 7-17. [71].

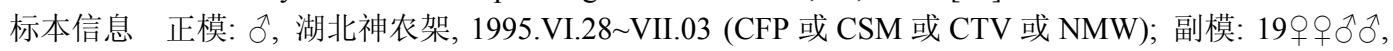
同正模; 2 ○, 湖北神农架, 2000.VI.15 (CFP 或 CSM 或 CTV 或 NMW)。

(112) Trigonognatha hubeica Facchini et Sciaky

Facchini S. and Sciaky R. Koleopterologische Rundschau, 73, 7-17. [71].

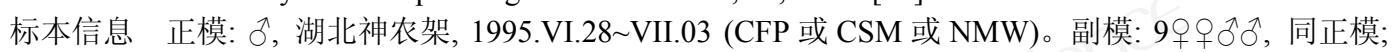
64 웅ㅅ, 湖北神农架, 2002.VI.12 (CFP 或 CSM 或 NMW)。

45. Cerambycidae 天牛科

(113) Distenia shennongjiaensis Pu 神农架瘦天牛

蒲富基. 1985. Acta Zootaxonomica Sinica (动物分类学报), 10(4), 427-430. [72].

标本信息 正模: §, 湖北神农架大九湖, 1981.VIII.02 (IZ-CAS)。

(114) Eutetrapha cinnabarina $\mathrm{Pu}$ 朱红直脊天牛

蒲富基. 1986. Acta Zootaxonomica Sinica (动物分类学报), 11(2), 201-202. [73].

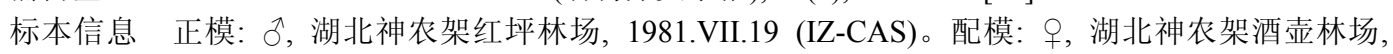
1981.VII.08 (IZ-CAS)。

(115) Necydalis rufiabdominis Chen 红腹膜天牛 
周友兵, 余小林, 吴楠, 申国珍, 熊高明, 徐文婷, 焚大勇, 赵常明, 谢宗强. 神农架世界自然遗产地动物模 式标本名录. 生物多样性, 2017, 25 (5): 513-517.

http://www.biodiversity-science.net/CN/10.17520/biods.2017032

陈树蝽. 1991. Acta Entomologica Sinica (昆虫学报), 34(3), 344-345. [74].

标本信息 正模: ㅇ, 湖北神农架红坪林场, 1987.VII.02 (BFU)。

(116) Rhondia hubeiensis Wang et Chang 鄂肩花天牛

王文凯和蒋书楠. 1994. Entomotaxonomia (昆虫分类学报), 16(3), 192-196. [75].

标本信息 正模: ㅇ, 湖北神农架林区, 1979.VII.05 (SWU)。

46. Chrysomelidae 叶甲科

(117) Gonioctena (Brachyphytodecta) andrzeji Daccordi et Ge 拟黑盾角胫叶甲

Ge SQ et al. 2007. Genus, 18(4), 579-587. [76].

标本信息 正模: $\delta$, 湖北神农架木鱼, 1997.VI.12 VI.15 (IZ-CAS 或 CBV 或 CDV 或 CKH 或 CWW)。

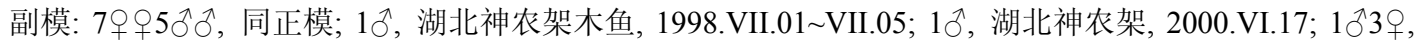
湖北神农架, 1998.VII.01 VII.05; 3ㅇ, 湖北神农架, 2001.VI.21 VI.24; 19, 湖北神农架, 1981.V.26; 1 9 , 神 农架红花朵林场, 1981.VII.25; 3ð1 9 , 湖北神农架红坪林场, 1981.VI.25; 5万, 神农架红坪林场,

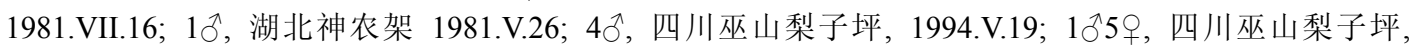

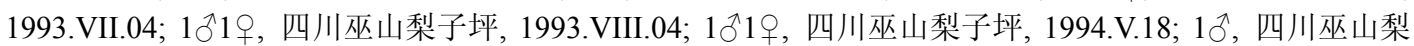

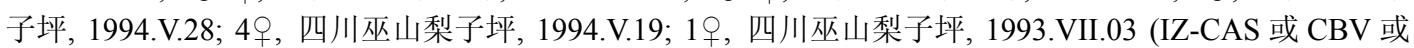
$\mathrm{CDV}$ 或 $\mathrm{CKH}$ 或 $\mathrm{CWW})$ 。

(118) Gonioctena (Gonioctena) warchalowskii Daccordi et Ge 沃氏角胫叶甲

Ge SQ et al. 2007. Genus, 18(4), 579-587. [76].

标本信息 正模: 今, 湖北神农架木鱼, 1999.VI.12 VI.15 (IZ-CAS 或 NHML 或 CDV)。副模: 19, 同正 模; $3 \precsim 1$ \% , 湖北神农架, 2000.VI.17 (IZ-CAS 或 NHML 或 CDV)。

(119) Japonitata hongpingana Jiang 红坪日萤叶甲

姜胜利. 1989. Acta Entomologica Sinica (昆虫学报), 32(2), 221-225. [77].

标本信息 正模: 今, 湖北神农架红坪, 1980.VII.13 (IZ-CAS 或 SEM)。

(120) Pseudespera femoralis Chen, Wang et Jiang 花股丝萤叶甲

陈世骧等. 1985. Acta Zoologica Sinica (动物学报), 31(4), 372-376. [78]

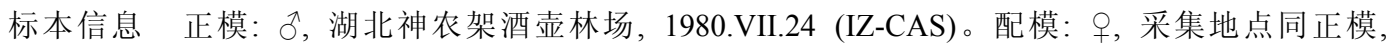
1981.VII.09 (IZ-CAS)。副模: 3 우，同正模; 132 万市，同配模。

(121) Pseudespera shennonguana Chen, Wang et Jiang 神农架丝萤叶甲

陈世榱等. 1985. Acta Zoologica Sinica (动物学报), 31(4), 372-376. [78].

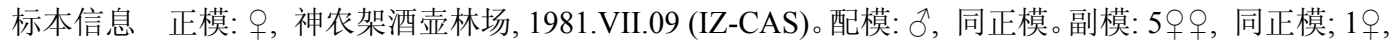
湖北神农架木鱼坪, 1981.VII.05; 19，湖北神农架酒売林场, 1980.VII.24 (IZ-CAS)。

(122) Taipinus convexus Daccordi et Ge 凸背圆胸叶甲

GE SQ et al. 2011. Systematic Entomology, 36, 644-671. [79].

标本信息 正模: 今, 湖北神农架大巴山木鱼坪, 2001.VII.22 (IZ-CAS 或 CDV)。副模: $1{ }^{\lambda}$, 湖北神农架 大巴山木鱼坪, 2001.VII.16 VII.22 (IZ-CAS 或 CDV)。

47. Coccinellidae 慓虫科

(123) Asemiadalia spiculimaculata Jing 矛斑突角慓虫

经希立. 1986. Acta Zootaxonomica Sinica (动物分类学报), 11(2), 205-208. [80].

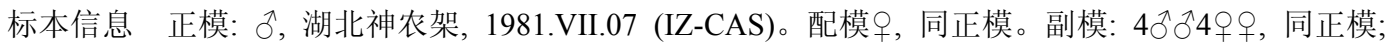

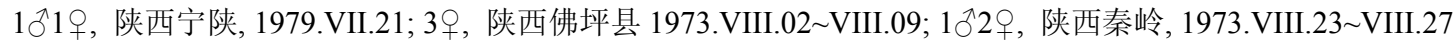
(IZ-CAS)。

(124) Scymnus (Pullus) ancontophyllus Ren et Pang 箭叶小飘虫

任顺祥和庞雄飞. 1993. Journal of South China Agricultural University (华南农业大学学报), 14(3), 6-9. [81].

标本信息 正模: §, 湖北神农架, 1989.VII.15 (SCAU)。副模:1ð，同正模; 1ð，湖北武当山, 1989.VII.18 (SCAU)。

(125) Scymnus (Pullus) cibagouensis Chen et Ren

Chen XS et al. 2015. Annales Zoologici, 65(3), 295-408. [82].

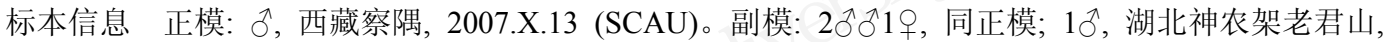

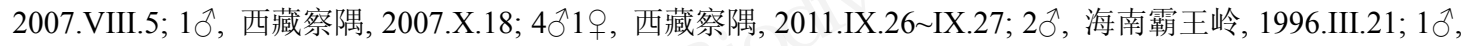

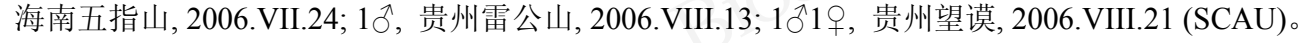

(126) Scymnus (Pullus) eminulus Chen et Ren

Chen XS et al. 2015. Annales Zoologici, 65(3), 295-408. [82].

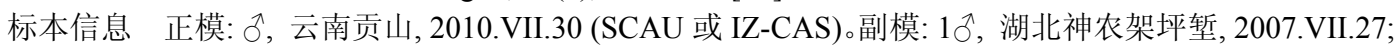

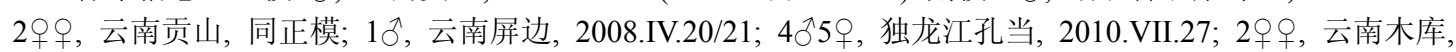


周友兵, 余小林, 吴楠, 申国珍, 熊高明, 徐文婷, 焚大勇, 赵常明, 谢宗强. 神农架世界自然遗产地动物模 式标本名录. 生物多样性, 2017, 25 (5): 513-517.

http://www.biodiversity-science.net/CN/10.17520/biods.2017032

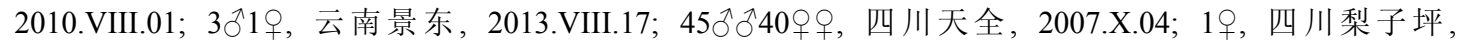
2007.IX.26 IX.27; 19，四川攀枝花, 2007.IX.16 (SCAU 或 IZ-CAS)。

(127) Scymnus (Pullus) inclinatus Chen et Ren

Chen XS et al. 2015. Annales Zoologici, 65(2), 187-237. [83].

标本信息 正模: 今, 河南南阳, 2009.VII.09 (SCAU 或 IZ-CAS)。副模: 1つ, 湖北神农架坪堑, 2007.VII.27; $3 \hat{\jmath} 8$ 우, 同正模; $1 \hat{\jmath}$, 河南洛阳, 2009.VII.11 VII.12; 1ㅇ, 河南南阳宝天曼, 2009.VII.07 VII.08; $1 \overbrace{}^{\lambda} 1$, 陕 西西安长安, 2009.VII.30 (SCAU 或 IZ-CAS)。

(128) Scymnus (Pullus) thecacontus Ren et Pang 套矛毛漂虫

任顺祥和庞雄飞. 1993. Journal of South China Agricultural University (华南农业大学学报), 14(3), 6-9. [81].

标本信息 正模: 今, 湖北神农架, 1989.VII.10 (SCAU)。

(129) Scymnus (Pullus) wudangensis Chen et Ren

Chen XS et al. 2015. Annales Zoologici, 65(2), 187-237. [83].

标本信息 正模: $\delta$, 湖北十堰武当山, 2007.VIII.08 (SCAU 或 IZ-CAS)。副模: 29 早, 湖北神农架板桥, 2007.VII.21 24; $7 \lesssim \precsim 12$ 우, 同正模; 1ð, 采集地点同正模, 1997.VII.17 (SCAU 或 IZ-CAS)。

48. Elateridae 吒甲科

(130) Zorochros hubeiensis Schimmel et Tarnawski

Schimmel R and Tarnawski D. 2012. Annales de la Société entomologique de France, 48(3-4), 347-362. [84]. 标本信息 正模： $\curvearrowright$, 湖北巴东, 2003.VI.26 VII.10 (CSV)。副模:1ð22웅, 同正模; 湖北大别山, 2003.VI.17 18; 湖北通山, 2003.VI.6 19 (CSV)。

49. Lagriidae 伪叶甲科

(131) Cerogria ommalata Chen 细眼角伪叶甲

杨星科主编. 1997. In: Insects of the Three Gorge reservoir area of Yangtze River (长江三峡库区昆虫), pp. 747. [49].

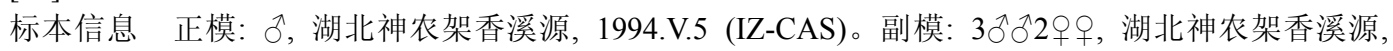
1994.V.4/5 (IZ-CAS)。

50. Leiodidae 球草甲科

(132) Ptomaphaginus luoi Wang et Zhou 罗氏锯尸小葬甲

Wang and Zhou. 2015. Zootaxa, 3941(3), 301-338. [85].

标本信息 正模: §。, 湖北神农架九冲干沟, 1998.VII.19 (IZ-CAS)。

(133) Ptomaphaginus shennongensis Wang et Zhou 神农锯尸小葬甲

Wang and Zhou. 2015. Zootaxa, 3941(3), 301-338. [85].

标本信息 正模: §, 湖北神农架龙门河, 2002.VII.28 VII.30 (IZ-CAS)。副模: 8 9 , 同正模; $2 ð 2$, 湖 北神农架九冲干沟, 1998.VII.18 VII.21；19, 湖北神农架九冲万家沟, 1998.VII.19；10，湖北神农架官门山, 1998.VII.30 VIII.11 (IZ-CAS)。

51. Melolonthidae 鰓角金龟科

(134) Hoplia platyca Zeng 宽扁单爪蛖

曾虹. 1986. Entomotaxonomia (昆虫分类学报), 8(4), 271-275. [86].

标本信息 正模: §, 湖北神农架大九湖, 1977.VI (NU)。副模: $2 \precsim ð$, 同正模 (NU)。

52. Scarabaeidae 金龟科

(135) Neoserica (s.l.) shennongjiaensis Liu, Fabrizi, Bai, Yang et Ahrens

Liu et al. 2014. ZooKeys, 440, 89-113. [87].

标本信息 正模: ふ, 湖北神农架红花, 1980.VII.26 (IZ-CAS 或 ZFKB 或 HU)。副模 1ㅇ, 同正模; $1 \delta$, 山 西中条山, 1995.VII.30; 10, 云南锦屏, 1956.V.15; 10, 贵州道真, 2004.VIII.17 VIII.21; 10, 河南嵩县, 2008.VIII.14 VIII.17 (IZ-CAS 或 ZFKB 或 HU)。

53. Staphylinidae 隐翅虫科

(136) Bolitogyrus metallicus Cai, Zhao et Zhou

Cai et al. 2015. Zootaxa, 3955 (4), 451-486. [88].

标本信息 正模: $\widehat{\partial}$, 湖北神农架自然保护区坪堑, 2005.IX.26 (IZ-CAS)。

(137) Dianous calvicollis Puthz

Volker PUTHZ. 2016. Linzer Biologische Beitraege, 48(1), 705-778. [89].

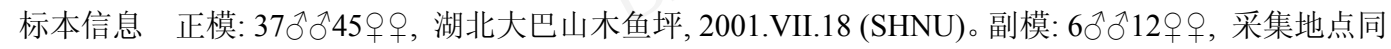

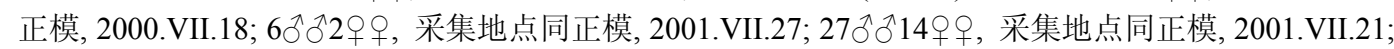
$40 \overbrace{}^{\lambda} 33$ 우, 湖北神农架木鱼, 2003.IX.03; $5 \overbrace{}^{\lambda} 7$ 웅, 陕西祁连山, 2001.VII.05 (SHNU)。

(138) Lobrathium rutilum Li, Solodovinikov et Zhou 
周友兵, 余小林, 吴楠, 申国珍, 熊高明, 徐文婷, 焚大勇, 赵常明, 谢宗强. 神农架世界自然遗产地动物模 式标本名录. 生物多样性, 2017, 25 (5): 513-517.

http://www.biodiversity-science.net/CN/10.17520/biods.2017032

Li et al. 2013. Zootaxa, 3635(5), 569-578. [90].

标本信息 正模: §̋, 湖北神农架干沟, 1998.VIII.1 VIII.8 (IZ-CAS)。

(139) Zyras (Zyras) nigricornis Assing

Assing V. 2016. Stuttgarter Beiträge zur Naturkunde A (Neue Serie), 9, 87-175. [91].

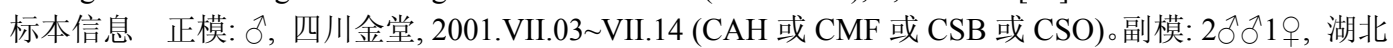

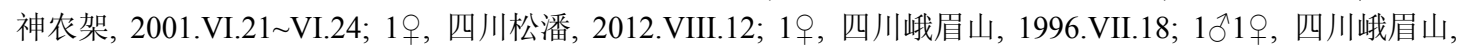

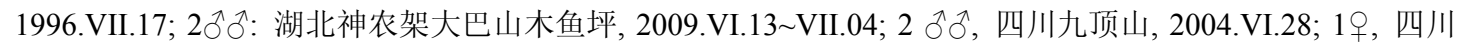

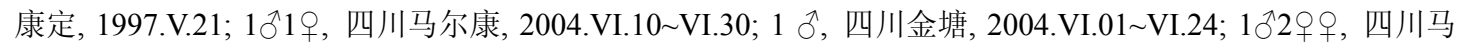
尔康, 2004.VI.9 VI.02; 19, 四川, 2006.VI.05; 29, 甘肃武都, 2005.VI.20; 7 只, 性别不详, 陕西大巴山镇坪, 2001.VII.13; 4 只, 性别不详, 陕西秦岭, 2001.VII.25 VII.26; 3 只, 性别不详, 湖北大巴山木鱼坪, 2001.VII.17 VII.21; 19, 青海门源, 2011.VII.05 (CAH 或 CMF 或 CSB 或 CSO)。

(140) Zyras (Zyras) rufoterminalis Assing

Assing V. 2016. Stuttgarter Beiträge zur Naturkunde A (Neue Serie), 9, 87-175. [91].

标本信息 正模: $\widehat{\jmath}$, 湖北神农架大巴山木鱼坪, 采集时间不详 (CAH 或 CSB)。副模: $2 \hat{\jmath} 3$ 우, 四川 九顶山, 2004.VI.07 VI.28; 1ㅇ, 四川, 2004.VI.07 VI.28; 10, 湖北神农架大巴山木鱼坪, 2001.VII.16 VII.16 (CAH 或 CSB)。

54. Tenebrionidae 拟步甲科

(141) Laena dabashanica Schawaller 大巴山莱甲

Schawaller W. 2008. Stuttgarter Beiträge zur Naturkunde Serie A (Neue Serie) 1, 387-411. [92].

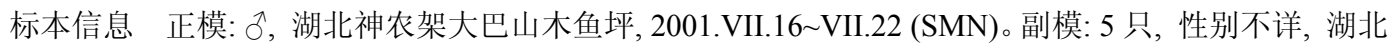
大巴山木鱼坪, 2002.VII.16 VII.22 (CSO 或 CSW)。

(142) Laena hubeica Schawaller 湖北莱甲

Schawaller W. 2001.Stuttgarter Beiträge zur Naturkunde Serie A (Biologie), 632, 1-62. [93].

标本信息 正模: §, 湖北神农架自然保护区, 1995.VI.03 VI.08 (HNHM)。副模: 5 只, 性别不详, 湖北 神农架自然保护区, 1995.VI.04 VI.08 (SMN 或 CTK)。

(十六) Mecoptera 长翅目

55. Bittacidae 蚊蝎蛉科

(143) Bittacus setigerus Chen, Tan et Hua 具毛蚊蝎蛉

Chen et al. 2013. Journal of Natural History, 47(21-22), 1463-1480. [94].

标本信息 正模：牛, 湖北巴东绿葱坡天三坪, 2006.VII.16 (NAFU)。副模：1웃, 湖北神农架,

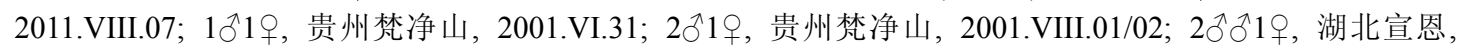
1989.VII.30 (CAV 或 SEM)。

(十七) Diptera 双翅目

56. Bibionidae 毛蚊科

(144) Bibio femoraspinatus Yang 棘腿毛蚊

杨星科主编. 1997. In: Insects of the Three Gorge reservoir area of Yangtze River (长江三峡库区昆虫), pp. 1445. [49].

标本信息 正模: ㅇ, 湖北神农架香溪源, 1994.V.05 (CAU 或 IZ-CAS)。

57. Bombyliidae 蜂虬科

(145) Systropus hubeianus Du, Yang, Gang et Yang 湖北姬蜂蚈

杜进平等. 2008. In: Classification and distribution of insects in China (昆虫分类与分布), pp. 3-19. [95].

标本信息 正模: 今, 湖北神农架松柏, 1985.VIII.29 (CAU)。配模: ，同正模。

(146) Systropus maoi Du, Yang, Gang et Yang 茅氏姬蜂蚈

杜进平等. 2008. In: Classification and distribution of insects in China (昆虫分类与分布), pp. 3-19. [95].

标本信息 正模: 今, 湖北神农架, 1982.VIII.10 (CAU)。

(147) Systropus melanocerus Du, Yang, Gang et Yang 黑角姬蜂蚈

杜进平等. 2008. In: Classification and distribution of insects in China (昆虫分类与分布), pp. 3-19. [95]. 标本信息 正模: 今, 湖北神农架松柏, 1985.VIII.29 (CAU)。配模: ㅇ, 同正模。

(148) Systropus shennonganus Du, Yang, Gang et Yang 神农姬蜂蚈

杜进平等. 2008. In: Classification and distribution of insects in China (昆虫分类与分布), pp. 3-19. [95].

标本信息 正模: §, 湖北神农架, 1985.VIII.22 (CAU)。

58. Celyphidae 甲蝇科

(149) Oocelyphus shennongjianus Yang et Yang 神农架卵甲蝇

杨金英和杨定. 2014. Entomotaxonomia (昆虫分类学报), 36(1), 55-60. [96].

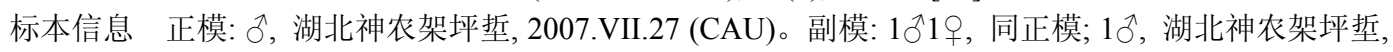


周友兵, 余小林, 吴楠, 申国珍, 熊高明, 徐文婷, 焚大勇, 赵常明, 谢宗强. 神农架世界自然遗产地动物模 式标本名录. 生物多样性, 2017, 25 (5): 513-517.

http://www.biodiversity-science.net/CN/10.17520/biods.2017032

2007.VII.26; 2ð, 湖北神农架板桥, 2007.VII.23 (CAU)。

59. Chloropidae 秆蝇科

(150) Centorisoma mediconvexum Liu et Yang 中凸隆盾秆蝇

Liu XY and Yang D. 2014. Zootaxa, 3821(1), 101-115. [97].

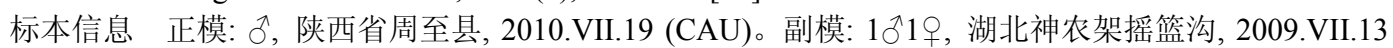

(CAU); $1 \jmath^{\Uparrow} 1$ 午, 四川峨眉山, 2010.VII.05 (CAU)。

60. Dolichopodidae 长足虻科

(151) Nepalomyia shennongjiaensis Wang, Chen et Yang

Wang MQ et al. 2014. Zoological Systematics, 39(3), 411-416. [98].

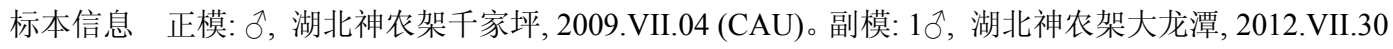

(CAU)。

61.Drosophilidae 果蝇科

(152) Amiota shennongi Shao et Chen

Shao ZF et al. 2014. Journal of Insect Science, 14, 33. [99].

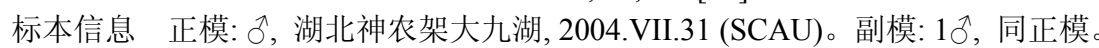

62. Empididae 舞虹科

(153) Chelipoda lyneborgi Yang et Yang 林氏鬃螳舞虻

杨定和杨集昆. 1990. Acta Zootaxonomica Sinica (动物分类学报), 15(4), 483-488. [100].

标本信息 正模: 古, 湖北神农架大岩屋, 1984.VI.29 (CAU)

(154) Chelipoda shennongana Yang et Yang 神农鬃螳舞虹

杨定和杨集昆. 1990. Acta Zootaxonomica Sinica (动物分类学报), 15(4), 483-488. [100].

标本信息 正模: 9 , 湖北神农架大岩屋, 1984.VI.29 (CAU)。配模: 9 , 同正模。副模: $2 \delta^{\lambda} 2$ 우, 同正模。

(155) Chelipoda xanthocephala Yang et Yang 黄头鬃螳舞蚈

杨定和杨集昆. 1990. Acta Zootaxonomica Sinica (动物分类学报), 15(4), 483-488. [100].

标本信息 正模: ㅇ, 湖北神农架大岩屋, 1984.VI.29 (CAU)。

(156) Empis (Coptophlebia) apiciseta Liu, Li et Yang 端鬃缺脉舞蚈

刘晓艳等. 2010. Acta Zootaxonomica Sinica (动物分类学报), 35(4), 736-741. [101].

标本信息 正模: §, 湖北神农架官门山, 2009.VII.02 (CAU)。副模: 1ठ，同正模。

(157) Empis (Coptophlebia) basiflava Liu, Li et Yang 基黄缺脉舞蚟

刘晓艳等. 2010. Acta Zootaxonomica Sinica (动物分类学报), 35(4), 736-741. [101].

标本信息 正模: ㅇ, 湖北神农架官门山, 2009.VII.02 (CAU)。副模: 4우, 同正模。

(158) Empis (Coptophlebia) digitata Liu, Li et Yang 指突缺脉舞蚈

刘晓艳等. 2010. Acta Zootaxonomica Sinica (动物分类学报), 35(4), 736-741. [101].

标本信息 正模: §, 湖北神农架大龙潭, 2009.VII.01 (CAU)。副模: 1ð, 采集地点同正模, 2009.VI.28

(CAU)。

(159) Empis (Coptophlebia) pallipilosa Liu, Li et Yang 白毛缺脉舞蚈

刘晓艳等. 2010. Acta Zootaxonomica Sinica (动物分类学报), 35(4), 736-741. [101].

标本信息 正模: 今, 湖北神农架大龙潭, 2009.VI.28 (CAU)。

(160) Empis (Coptophlebia) postica Liu, Li et Yang 后鬃缺脉舞䗆

刘晓艳等. 2010. Acta Zootaxonomica Sinica (动物分类学报), 35(4), 736-741. [101].

标本信息 正模: 今, 湖北神农架漳宝河, 2009.VII.03 (CAU)。

(161) Hilara acuticercus Li, Cui et Yang 须尖喜舞蚟

李竹等. 2010. Acta Zootaxonomica Sinica (动物分类学报), 35(4), 745-749. [102].

标本信息 正模: $\precsim$, 湖北神农架大龙潭, 2009.VI.28 (CAU)。副模: $2 \precsim ð$, 同正模。

(162) Hilara basiprojecta Liu, Li et Yang 基突喜舞虻

刘启飞等. 2010. Entomotaxonomia (昆虫分类学报), 32(Suppl.), 61-70. [103].

标本信息 正模: §, 湖北神农架坪埑, 2009.VII.06 (CAU)。副模: $2 \hat{\jmath}$, 湖北神农架大龙潭, 2009.VII.1 (CAU)。

(163) Hilara bispina Li, Cui et Yang 双刺喜舞䗆

李竹等. 2010. Acta Zootaxonomica Sinica (动物分类学报), 35(4), 745-749. [102].

标本信息 正模: 今, 湖北神农架大龙潭, 2009.VI.29 (CAU)。

(164) Hilara brevifurcata Liu, Li et Yang 短叉喜舞䗆

刘启飞等. 2010. Entomotaxonomia (昆虫分类学报), 32(3), 195-200. [104].

标本信息 正模: $\curvearrowright$, 湖北神农架坪埑, 2009.VII.08 (CAU)。

(165) Hilara brevis Liu, Li et Yang 短角喜舞蚈 
周友兵, 余小林, 吴楠, 申国珍, 熊高明, 徐文婷, 焚大勇, 赵常明, 谢宗强. 神农架世界自然遗产地动物模 式标本名录. 生物多样性, 2017, 25 (5): 513-517.

http://www.biodiversity-science.net/CN/10.17520/biods.2017032

刘启飞等. 2010. Entomotaxonomia (昆虫分类学报), 32(3), 195-200. [104].

标本信息 正模: §, 湖北神农架大龙潭, 2009.VI.29 (CAU)。

(166) Hilara curvata Liu, Li et Yang 弯须喜舞蚈

刘启飞等. 2010. Entomotaxonomia (昆虫分类学报), 32(Suppl.), 61-70. [103].

标本信息 正模: Љ, 湖北神农架大龙潭, 2009.VI.27 (CAU)。副模: 19, 同正模。

(167) Hilara curviphallus Liu, Li et Yang 弯茎喜舞蚈

刘启飞等. 2010. Entomotaxonomia (昆虫分类学报), 32(Suppl.), 61-70. [103].

标本信息 正模: ふ, 湖北神农架坪埑, 2009.VII.06 (CAU)。副模: 2ðð, 同正模。

(168) Hilara digitiformis Liu, Li et Yang 指突喜舞蚈

刘启飞等. 2010. Entomotaxonomia (昆虫分类学报), 32(Suppl.), 61-70. [103].

标本信息 正模: 今, 湖北神农架大龙潭, 2009.VII.01 (CAU)。

(169) Hilara dalongtana Liu, Li et Yang 大龙潭喜舞虹

刘启飞等. 2010. Entomotaxonomia (昆虫分类学报), 32(3), 195-200. [104].

标本信息 正模: 今, 湖北神农架大龙潭, 2009.VI.29 (CAU)。

(170) Hilara flata Liu, Li et Yang 平突喜舞蚈

刘启飞等. 2010. Entomotaxonomia (昆虫分类学报), 32(Suppl.), 61-70. [103].

标本信息 正模: $\curvearrowright$, 湖北神农架坪埑, 2009.VII.06 (CAU)。副模: $1 \delta 1$, 同正模。

(171) Hilara longa Liu, Li et Yang 长角喜舞䗑

刘启飞等. 2010. Entomotaxonomia (昆虫分类学报), 32(3), 195-200. [104].

标本信息 正模: §, 湖北神农架坪埑, 2009.VII.06 (CAU)。

(172) Hilara longicercus Li, Cui et Yang 长须喜舞虹

李竹等. 2010. Acta Zootaxonomica Sinica (动物分类学报), 35(4), 745-749. [102].

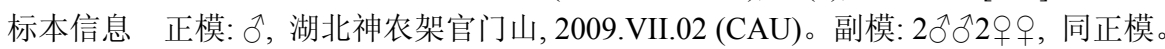

(173) Hilara longiseta Li, Cui et Yang 长䯽喜舞虬

李竹等. 2010. Acta Zootaxonomica Sinica (动物分类学报), 35(4), 745-749. [102].

标本信息 正模: 今, 湖北神农架大龙潭, 2009.VI.28 (CAU)。副模: $2 \hat{\jmath}$, 同正模。

(174) Hilara obtuse Liu, Li et Yang 针突喜舞蚈

刘启飞等. 2010. Entomotaxonomia (昆虫分类学报), 32(Suppl.), 61-70. [103].

标本信息 正模: ふ, 湖北神农架大龙潭, 2009.VI.27 (CAU)。副模: 1ð, 同正模。

(175) Hilara spina Li, Cui et Yang 刺突喜舞蚈

李竹等. 2010. Acta Zootaxonomica Sinica (动物分类学报), 35(4), 745-749. [102].

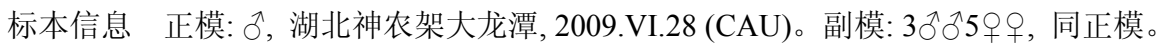

(176) Hybos bigeniculatus Yang et Yang 双膝驼舞虹

杨集昆和杨定. 1991. Journal of Hubei University (Natural Science) (湖北大学学报(自然科学版)), 13(1),

1-8. [105].

标本信息 正模: ふ, 湖北神农架大岩屋, 1984.VI.28 (CAU)。配模: 1，同正模。

(177) Hybos concavus Yang et Yang 凹缘驼舞虹

杨集昆和杨定. 1991. Journal of Hubei University (Natural Science) (湖北大学学报(自然科学版)), 13(1),

1-8. [105].

标本信息 正模: 今, 湖北神农架大岩屋, 1984.VI.29 (CAU)。

(178) Hybos guanmenshanus Huo, Zhang et Yang

Huo S et al. 2010. Transactions of the American Entomological Society, 136(3+4), 251-254. [106].

标本信息 正模: 今, 湖北神农架官门山, 2009.VII.02 (CAU)。

(179) Hybos latus Huo, Zhang et Yang

Huo S et al. 2010. Transactions of the American Entomological Society, 136(3+4), 251-254. [106].

标本信息 正模: 今, 湖北神农架阴峪河, 2009.VII.18 (CAU)。

(180) Hybos shennongensis Yang et Yang 神农驼舞蛇

杨集昆和杨定. 1991. Journal of Hubei University (Natural Science) (湖北大学学报(自然科学版)), 13(1),

1-8. [105].

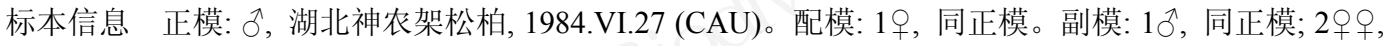
湖北神农架大岩屋, 1984.VI.29 (CAU)。

(181) Platypalpus brevis Huo, Zhang et Yang

Huo S et al. 2010. Transactions of the American Entomological Society, 136(3+4), 259-262. [107].

标本信息 正模: 今, 湖北神农架坪堑, 2009.VII.07 (CAU)。

(182) Platypalpus didymus Huo, Zhang et Yang 
周友兵, 余小林, 吴楠, 申国珍, 熊高明, 徐文婷, 焚大勇, 赵常明, 谢宗强. 神农架世界自然遗产地动物模 式标本名录. 生物多样性, 2017, 25 (5): 513-517.

http://www.biodiversity-science.net/CN/10.17520/biods.2017032

Huo S et al. 2010. Transactions of the American Entomological Society, 136(3+4), 259-262. [107].

标本信息 正模: 今, 湖北神农架大龙潭, 2009.VI.27 (CAU)。

(183) Rhamphomyia (Rhamphomyia) flavella Yu, Liu et Yang 基黄猎舞蚈

余慧等. 2010. Acta Zootaxonomica Sinica (动物分类学报), 35(3), 475-477. [108].

标本信息 正模: 今, 湖北神农架大龙潭, 2009.VI.29 (CAU)。

(184) Rhamphomyia (Rhamphomyia) projecta Yu, Liu et Yang 内突猎舞蚈

余慧等. 2010. Acta Zootaxonomica Sinica (动物分类学报), 35(3), 475-477. [108].

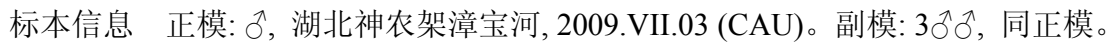

(185) Sinohilara shennongana Zhou, Li et Yang 神农华喜舞虹

周丹等. 2010. Acta Zootaxonomica Sinica (动物分类学报), 35(3), 478-480. [109].

标本信息 正模: 今, 湖北神农架坪埑, 2009.VII.07 (CAU)。副模: $6 \hat{\jmath} \hat{\jmath}$, 同正模。

63. Muscidae 蝇科

(186) Coenosia changjianga Xue 长江秽蝇

杨星科主编. 1997. In: Insects of the Three Gorge reservoir area of Yangtze River (长江三峡库区昆虫), pp. 1503. [49].

标本信息 正模: Ô, 湖北神农架香溪源, 1994.V.05 (IZ-CAS)。副模: 1Ô, 湖北兴山县龙门河, 1994.V.6 (IZ-CAS)。

(187) Coenosia flavipenicillata Xue 黄笔秽蝇

杨星科主编. 1997. In: Insects of the Three Gorge reservoir area of Yangtze River (长江三峡库区昆虫), pp. 1505. [49].

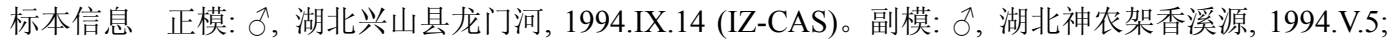
19, 湖北兴山县龙门河, 1994.V.06 (IZ-CAS)。

(188) Coenosia shennonga Xue 神农秽蝇

杨星科主编. 1997. In: Insects of the Three Gorge reservoir area of Yangtze River (长江三峡库区昆虫), pp. 1504. [49].

标本信息 正模: §, 湖北神农架香溪源, 1994.V.5 (IZ-CAS)。副模: $2 ð 2$ 우, 同正模; $1 ð$, 湖北兴山县龙 门河, 1994.V.07 (IZ-CAS)。

64. Mycetophilidae 菌蚊科

(189) Mycomya shennongana Yang et $\mathrm{Wu}$ 神农真菌蚊

杨集昆和吴鸿. 1989. Journal of Hubei University (Natural Science) (湖北大学学报(自然科学版)), 11(2),

61-64. [110].

标本信息 正模: つ, 湖北神农架大岩屋, 1984.VI.29 (CAU)。

65. Lauxaniidae 缟蝇科

(190) Minettia (Minettiella) clavata Shi et Yang

Shi L and Yang D. 2014. ZooKeys, 449, 81-103. [111].

标本信息 正模: $\curvearrowright$, 湖北神农架自然保护区坪堑, 2007.VII.26 (CAU)。副模: $4 \lesssim \precsim 1$, 采集地点同正模, 2007.VII.25; 4웅, 采集地点同正模, 2007.VII.27 (CAU)。

(191) Minettia (Plesiominettia) flavoscutellata Shi, Gaimari et Yang

Shi L et al. 2015. ZooKeys, 520, 61-86. [112].

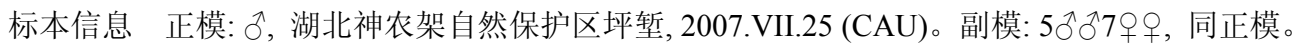

(192) Minettia (Frendelia) longifurcata Shi et Yang

Shi L and Yang D. 2014. Florida Entomologist, 97(4), 1511-1528. [113].

标本信息 正模: §̋, 湖北神农架自然保护区老君山, 2007.VIII.4 (CAU)。副模: 9ððð, 采集地点同正模, 2007.VIII.3 VIII.5 (CAU)。

(193) Minettia (Minettiella) plurifurcata Shi et Yang

Shi L and Yang D. 2014. ZooKeys, 449, 81-103. [111].

标本信息 正模: つ, 湖北神农架自然保护区坪埑, 2007.VII.26 (CAU)。

(194) Minettia (Minettiella) spinosa Shi et Yang

Shi L and Yang D. 2014. ZooKeys, 449, 81-103. [111].

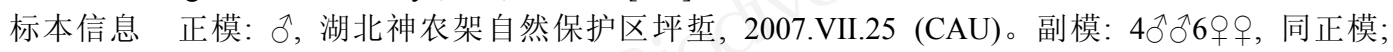
$6 \hat{\jmath} 5$ 우, 采集地点同正模, 2007.VII.27 (CAU)。

66. Rhagionidae 璚虻科

(195) Chrysppilus apicimaculatus Yang et Yang 端黑金璚䗆

杨集昆和杨定. 1991. Journal of Hubei University (Natural Science) (湖北大学学报(自然科学版)), 13(3), 273-277. [114]. 
周友兵, 余小林, 吴楠, 申国珍, 熊高明, 徐文婷, 焚大勇, 赵常明, 谢宗强. 神农架世界自然遗产地动物模 式标本名录. 生物多样性, 2017, 25 (5): 513-517.

http://www.biodiversity-science.net/CN/10.17520/biods.2017032

标本信息 正模: 今, 湖北神农架大岩屋, 1984.VI.29 (CAU)。

(196) Chrysopilus hubeiensis Yang et Yang 湖北金璚虹

杨集昆和杨定. 1991. Journal of Hubei University (Natural Science) (湖北大学学报(自然科学版)), 13(3),

273-277. [114].

标本信息 正模: つ, 湖北神农架松柏, 1980.VI.24 (CAU)。

(197) Chrysopilus nagatomii Yang et Yang 永富金鹬蚈

杨集昆和杨定. 1991. Journal of Hubei University (Natural Science) (湖北大学学报(自然科学版)), 13(3), 273-277. [114].

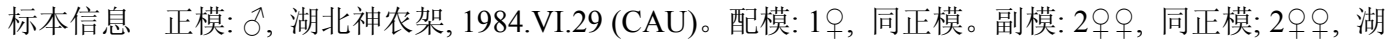
北神农架, 1985.V.30/VI.15; 19, 湖北神农架大岩屋, 1984.VI.29 (CAU)。

(198) Rhagio apiciflavus Yang et Yang 端黄璚蛇

杨集昆和杨定. 1991. Journal of Hubei University (Natural Science) (湖北大学学报(自然科学版)), 13(3),

273-277. [114].

标本信息 正模: ぶ, 湖北神农架大岩屋, 1984.VI.29 (CAU)。

(199) Rhagio shennonganus Yang et Yang 神农璚虹

杨集昆和杨定. 1991. Journal of Hubei University (Natural Science) (湖北大学学报(自然科学版)), 13(3),

273-277. [114].

标本信息 正模: ㅇ, 湖北神农架, 1980.VII.23 (CAU)。

67. Sciaridae 眼草蚊科

(200) Pseudozygoneura hexacantha Shi et Huang

Huang JH et al. 2015. Entomological News, 125(2), 77-95. [115].

标本信息 正模: §, 陕西户县, 2012.VII.12 (ZAFU)。副模: 2ð, 湖北神农架阴峪河, 2012.V.16 V.17; 1ठ,

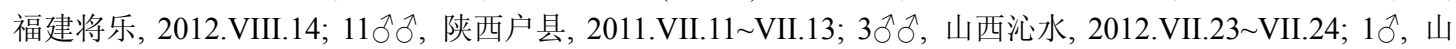
西沁水, 2012.VII.28; 1今, 浙江临安, 2010.VII.3 (ZAFU)。

(201) Pseudozygoneura robustispina Shi et Huang

Huang JH et al. 2015. Entomological News, 125(2), 77-95. [115].

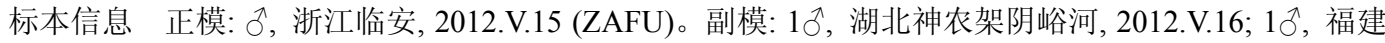
武夷山, 2012.IV.26 (ZAFU)。

(202) Peyerimhoffia shennongjiana Shi, Huang, Zhang et Wu

Shi K et al. 2014. ZooKeys, 382, 67-83. [116].

标本信息 正模: 今, 湖北神农架大龙潭, 2012.V.20 (ZAFU)。

68. Simuliidae 蚋科

(203) Simulium (Simulium) dentastylum Yang, Chen et Luo 齿端蚋

杨明等. 2009. Acta Zootaxonomica Sinica (动物分类学报), 34(3), 454-456. [117]

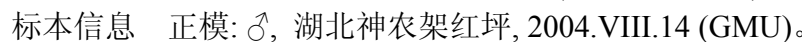

(204) Simulium (Simulium) hongpingense Chen, luo et Yang 红坪蚋

陈汉涁等. 2006. Acta Zootaxonomica Sinica (动物分类学报), 31(4), 874-879. [118].

标本信息 正模: 9 , 湖北神农架自然保护区, 采集时间不详 (GMU)。副模: $2 \hat{\jmath}$, 同正模。

(205) Simulium (Simulium) xiaolongtanense Chen, luo et Yang 小龙潭蚋

陈汉涁等. 2006. Acta Zootaxonomica Sinica (动物分类学报), 31(4), 874-879. [118].

标本信息 正模: 9 ，湖北神农架自然保护区，采集时间不详 (GMU)。副模: $193 \hat{\jmath} \widehat{\delta}$, 同正模。

69. Stratiomyidae 水虹科

(206) Allognosta caiqiana Li, Zhang et Yang 彩旗距水虹

李竹等. 2011. Acta Zootaxonomica Sinica (动物分类学报), 36(2), 273-277. [119].

标本信息 正模: + ，湖北神农架彩旗, 2009.VII.14 (CAU)。

(207) Allognosta dalongtana Li, Zhang et Yang 大龙潭距水蚈

李竹等. 2011. Acta Zootaxonomica Sinica (动物分类学报), 36(2), 273-277. [119].

标本信息 正模: 古, 湖北神农架大龙潭, 2009.VI.29 (CAU)。

(208) Beris shennongana Li, Luo et Yang 神农柱角水蚈

李竹等. 2009. Entomotaxonomia (昆虫分类学报), 31(2), 129-131. [120].

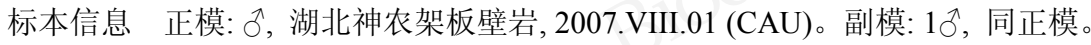

70. Tabanidae 虹科

(209) Tabanus longistylus Xu, Ni et Xu 长芒䗆

许荣满等. 1984. Journal of Wuhan Medical College (武汉医学院学报), 13(3), 164-166. [121].

标本信息 正模: ㅇ, 湖北长阳, 1957.IX.02 (AMMS)。副模: 1ㅇ，湖北神农架, 1980.VIII.7 (TMC-HUST)。 
周友兵, 余小林, 吴楠, 申国珍, 熊高明, 徐文婷, 樊大勇, 赵常明, 谢宗强. 神农架世界自然遗产地动物模 式标本名录. 生物多样性, 2017, 25 (5): 513-517.

http://www.biodiversity-science.net/CN/10.17520/biods.2017032

(210) Tabanus shennongjiaensis Xu, Ni et Xu 神农架虹

许荣满等. 1984. Journal of Wuhan Medical College (武汉医学院学报), 13(3), 164-166. [121].

标本信息 正模: 9 , 湖北竹山, 1980.VIII.8 (AMMS)。副模: 3우, 同正模; 31우, 湖北神农架, 1980.VII.22 (AMMS)。

71. Tipulidae 大蚊科

(211) Dictenidia knutsoni Yang et Yang 孔氏偶栉大蚊

杨定和杨集昆. 1989. Acta Agriculturae Universitatis Pekinensis (北京农业大学学报), 15(1), 69-73. [122]. 标本信息 正模: 早, 湖北神农架大岩屋, 1984.VI.28 (CAU)。

(212) Dictenidia partialis Yang et Yang 黄肩偶栉大蚊

杨定和杨集昆. 1989. Acta Agriculturae Universitatis Pekinensis (北京农业大学学报), 15(1), 69-73. [122].

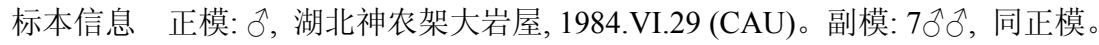

(213) Dictenidia subpartialis Yang et Yang 拟黄肩偶栉大蚊

杨定和杨集昆. 1989. Acta Agriculturae Universitatis Pekinensis (北京农业大学学报), 15(1), 69-73. [122]. 标本信息 正模: 今, 湖北神农架大岩屋, 1984.VI.29 (CAU)。

(214) Macgregoromyia flatusa Liu et Yang 平脊叉纤足大蚊

Liu QF and Yang D. 2011. Zootaxa, 2802, 41-50. [123].

标本信息 正模: 今, 湖北神农架松柏, 1984.V.29 (CAU)。

(215) Nephrotoma geniculata Yang et Yang 膝突短柄大蚁

杨集昆和杨定. 1987. Journal of Huazhong Agricultural University (华中农业大学学报), 6(2), 130-137. [124].

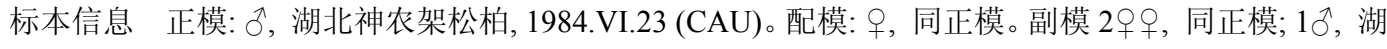
北武当山紫霄宫, 1984.V.28; 10^, 四川昭觉, 1983.VIII; 1万人, 内蒙大青山, 1978.VII.23 (CAU)。

(216) Tanyptera hubeiensis Yang et Yang 湖北奇栉大蚊

杨定和杨集昆. 1988. Journal of Hubei University (Natural Science) (湖北大学学报(自然科学版)), 10(2),

70-74. [125].

标本信息 正模: 今, 湖北神农架大岩屋, 1984.VI.29 (CAU)。副模: $2 \hat{\jmath}$, 同正模。

(217) Tanyptera shennongana Yang et Yang 神农奇栉大蚊

杨定和杨集昆. 1988. Journal of Hubei University (Natural Science) (湖北大学学报(自然科学版)), 10(2),

70-74. [125].

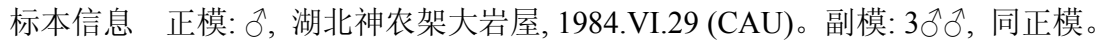

(218) Tipula (Acutipula) buboda Yang et Yang 宽突尖大蚊

杨集昆和杨定. 1992. Journal of Hubei University (Natural Science) (湖北大学学报(自然科学版)), 14(3),

263-269. [126].

标本信息 正模: ぶ, 湖北神农架大岩屋, 1984.VI.29 (CAU)。

(219) Tipula (Acutipula) cranicornuta Yang et Yang 角冠尖大蚊

杨集昆和杨定. 1992. Journal of Hubei University (Natural Science) (湖北大学学报(自然科学版)), 14(3),

263-269. [126].

标本信息 正模: §, 湖北神农架松柏镇, 1984.VI.23/27 (CAU)。配模: ㅇ, 同正模。副模: 1，同正模。

(220) Tipula (Acutipula) hubeiana Yang et Yang 湖北尖大蚊

杨集昆和杨定. 1992. Journal of Hubei University (Natural Science) (湖北大学学报(自然科学版)), 14(3),

263-269. [126].

标本信息 正模: §, 湖北神农架大岩屋, 1984.VI.27/29 (CAU)。配模: ㅇ, 同正模。副模: 1，同正模。

(221) Tipula (Sinotipula) shennongana Yang et Yang 神农华大蚁

杨集昆和杨定. 1992. Journal of Hubei University (Natural Science) (湖北大学学报(自然科学版)), 14(3),

263-269. [126].

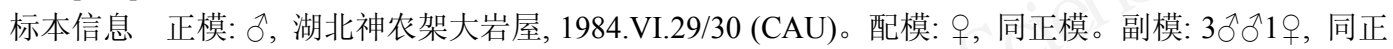
模。

(222) Tipula (Vestiplex) medioflava Yang et Yang 中黄蜚大蚁

杨定和杨集昆. 1999. Journal of China Agricultural University (中国农业大学学报), 4(Suppl.), 63-64. [127].

标本信息 正模: 今, 湖北神农架松柏县, 1984.VI.27 (CAU)。

(223) Tipula (Vestiplex) jiangi Yang et Yang 蒋氏蜚大蚊

杨定和杨集昆. 1991. Journal of Southwest Agricultural University (西北农林大学学报). 13(3), 252-254. [128].

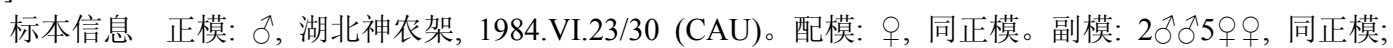


周友兵, 余小林, 吴楠, 申国珍, 熊高明, 徐文婷, 焚大勇, 赵常明, 谢宗强. 神农架世界自然遗产地动物模 式标本名录. 生物多样性, 2017, 25 (5): 513-517.

http://www.biodiversity-science.net/CN/10.17520/biods.2017032

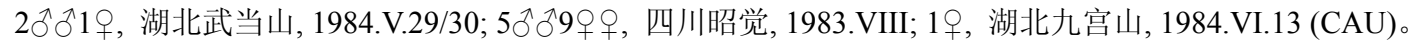

(224) Tipula (Vestiplex) xanthocephala Yang et Yang 黄头蜚大蚊

杨定和杨集昆. 1991. Journal of Southwest Agricultural University (西北农林大学学报). 13(3), 252-254. [128].

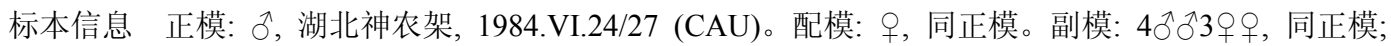
$3 \precsim \precsim 2$ 우, 湖北武当山, 1984.V.29/30; 9 ふ2웅, 四川昭觉, 1983.VIII. (CAU)。

72. Trypetidae 实蝇科

(225) Cyaforma shenonica Wang 神峨墨实蝇

汪兴鉴. 1989. Acta Zootaxonomica Sinica (动物分类学报), 14, 358-363. [129].

标本信息 正模：う，湖北神农架，1977.VII.27 (IZ-CAS)。配模: + , 同正模。副模 $1 \precsim 1$, 同正模; $9 \widehat{\jmath} 8$ ํㅜㅇ, 四川峨眉山, 1957.VI,VII.9 28 (IZ-CAS)。

(十八) Siphonaptera 蚤目

73. Ceratophyllidae 角叶蚤科

(226) Macrostylophora muyuensis Liu et Wang 木鱼大雉蚤

刘井元和王敦清. 1989. Acta Zootaxonomica Sinica (动物分类学报), 19(2), 238-242. [130].

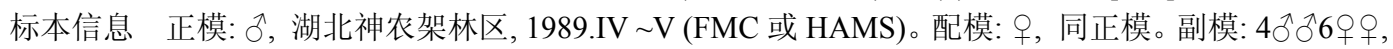
同正模。

74. Hystrichopsyllidae 多毛蚤科

(227) Ctenophthalmus exiensis Wang et Liu 鄂西栉眼蚤

王敦清和刘井元. 1989. Acta Zootaxonomica Sinica (动物分类学报), 18(4), 490-492. [131].

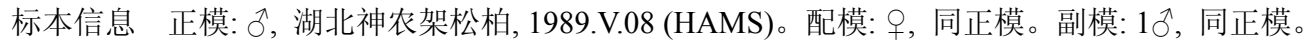

(228) Palaeopsylla mai Liu et Chen 马氏古蚤

刘井元和陈尚全. 2005. Acta Zootaxonomica Sinica (动物分类学报), 30(1), 194-198. [132].

标本信息 正模: 今, 湖北神农架大岩屋林场, 1995.VI.22 (AMMS)。

(229) Stenischia exiensis Wang et Liu 鄂西狭臀蚤

王敦清和刘井元. 1885. Acta Zootaxonomica Sinica (动物分类学报), 20(3), 363-365. [133].

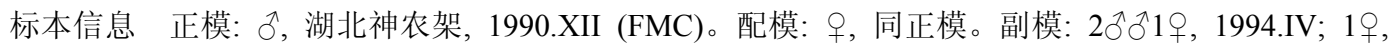
1990.VI (HAMS)。

75. Leptopsyllidae 细蚤科

(230) Geusibia liae Wang et Liu 李氏茸足蚤

王敦清和刘井元. 1989. Acta Zootaxonomica Sinica (动物分类学报), 20(1), 112-115. [134].

标本信息 正模: §。, 湖北神农架木鱼, 1989.VI 1990.IX (FMC 或 HAMS)。配模: 牛, 同正模。副模: $3{ }^{\lambda} \delta^{\lambda} 9$ 우, 同正模。

(231) Typhlomyopsyllus bashanensis Liu et Wang 巴山盲鼠蚤

刘井元和王敦清. 1990. Acta Zootaxonomica Sinica (动物分类学报), 20(2), 243-245. [135].

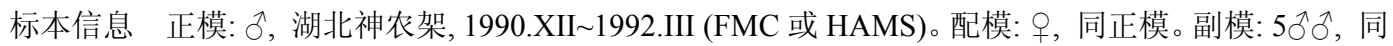
正模。

76. Vermipsyllidae 蠕形蚤科

(232) Chaetopsylla wangi Liu 王氏鬃蚤

刘井元. 1992. Acta Entomologica Sinica (昆虫学报), 40(1), 82-85. [136].

标本信息 正模: §, 湖北神农架, 1992.III.06 (HAMS)。

(十九) Trichoptera 毛翅目

77. Limnephilidae 沼石蛾科

(233) Apatania spiculata Yang et Wang 小穗埃沼石蛾

杨星科主编. 1997. In: Insects of the Three Gorge reservoir area of Yangtze River (长江三峡库区昆虫), pp. 989. [49].

标本信息 正模: §̋, 湖北神农架小龙潭, 1994.V.04 (IZ-CAS)。副模: 19, 湖北神农架香溪源, 1994.V.05 (IZ-CAS)。

(二十) Lepidoptera 鳞翅目

78. Arctiidae 灯蛾科

(234) Miltochrista griseirufa Fang 灰红美苔蛾

方承莱. 1991. Sinozoologia (动物学集刊), 8, 383-397. [137].

标本信息 正模: , 湖北神农架大九湖, 1981.VIII.02 (IZ-CAS)。副模: 1，采集地点同正模, 1981.VIII.05; 1웅, 湖北神农架红坪林场, 1981.VII.20 (IZ-CAS)。

(235) Miltochrista longstriga Fang 全轴美苔蛾 
周友兵, 余小林, 吴楠, 申国珍, 熊高明, 徐文婷, 焚大勇, 赵常明, 谢宗强. 神农架世界自然遗产地动物模 式标本名录. 生物多样性, 2017, 25 (5): 513-517.

http://www.biodiversity-science.net/CN/10.17520/biods.2017032

方承莱. 1991. Sinozoologia (动物学集刊), 8, 383-397. [137].

标本信息 正模: §̃，陕西秦岭宁陕, 1979.VII.30 (IZ-CAS)。配模: ㅇ, 陕西秦岭, 1979.VII.29 (IZ-CAS)。

副模: $5 \delta^{\lambda} \delta^{\lambda} 4$ 우, 陕西秦岭, 1979.VII.20 VII.31; 10, 陕西秦岭太白黄口坑, 1980.VII.17; 1 9 , 湖北兴山, 1980.VII.29; 19, 湖北神农架, 1981.VIII.01 (IZ-CAS)。

79. Drepanidae 钩蛾科

(236) Auzatella pentesticha Zhu et Wang 五线绢钩蛾

朱弘复和王林瑶. 1987. Sinozoologia (动物学集刊), 5, 105-122. [138].

标本信息 正模: + , 西藏曲乡, 1975.VII.07 (IZ-CAS)。配模: §, 西藏樟木, 1975.VI.26。副模: 2 우, 湖 北神农架, 1981.VIII.16 (IZ-CAS)。

(237) Betalbara safra Zhu et Wang 黄线卑钩蛾

朱弘复和王林瑶. 1987. Sinozoologia (动物学集刊), 5, 73-88. [139].

标本信息 正模: §, 湖北神农架九湖, 1981.VIII.01 (IZ-CAS)。

(238) Deroca akolosa Zhu et Wang 侏粉晶钩蛾

朱弘复和王林瑶. 1987. Sinozoologia (动物学集刊), 5, 105-122. [138].

标本信息 正模: ○, 湖北神农架, 1981.VII.16 (IZ-CAS)。

(239) Nordstroemia fusca Zhu et Wang 灰线钩蛾

朱弘复和王林瑶. 1988. Acta Entomologica Sinica (昆虫学报), 31(3), 309-316. [140].

标本信息 正模: 今, 湖北神农架, 1981.VIII.20 (IZ-CAS)。配模: 古, 湖北神农架, 1981.VIII.02 (IZ-CAS)。 副模: 1ठ, 湖北神农架, 1981.VIII.21; 1ठ, 福建武夷山, 1983, (IZ-CAS)。

(240) Nordstroemia niva Zhu et Wang 雪线钩蛾

朱弘复和王林瑶. 1988. Acta Entomologica Sinica (昆虫学报), 31(3), 309-316. [140].

标本信息 正模: 壬, 湖北神农架, 1981.VIII.16 (IZ-CAS)。副模: 1，同正模。

(241) Oreta ankyra Zhu et Wang 针山钩蛾

朱弘复和王林瑶. 1987. Acta Entomologica Sinica (昆虫学报), 30(3), 291-307. [141].

标本信息 正模: Љ, 湖北神农架, 1981.VIII.01 (IZ-CAS)。配模: ㅇ, 云南小预养, 1980.V.07 (IZ-CAS)。副

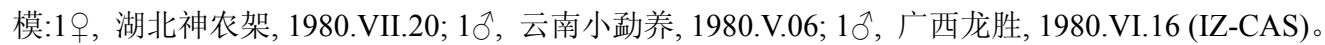

(242) Oreta trispinuligera Chen 三刺金钩蛾

陈小钰. 1992. Entomotaxononmia (昆虫分类学报), 7(4), 277-280. [142].

标本信息 正模: §̂, 湖北神农架红坪, 1983.VIII.10。副模: 1§, 湖北神农架松柏, 1983.VII.11 (SEM)。

80. Hesperiidae 弄蝶科

(243) Lobocla quadripunctata Fan et Wang 四纹带弄蝶

范骁凌和王敏. 2004. Acta Zootaxonomica Sinica (动物分类学报), 29(3), 523-526. [143].

标本信息 正模: O̊, 湖北神农架, 1992.VI (SCAU)。

81. Lithosiidae 苔蛾科

(244) Agylla latifascia Fang 宽条华苔蛾

方承莱. 1986. Sinozoologia (动物学集刊), 4, 180-182. [144].

标本信息 正模: §, 湖北神农架, 1981.VIII.01。配模: 早, 采集地点同正模, 1981.VIII.02。副模: $1 \precsim 1$, 采集地点同正模, 1981.VIII.01 VIII.03 (IZ-CAS)。

(245) Agylla serrata Fang 锯角华苔蛾

方承莱. 1986. Sinozoologia (动物学集刊), 4, 180-182. [144].

标本信息 正模: ぶ, 湖北神农架, 1981.VII.16 (IZ-CAS)。副模: 3ðð, 1981.VII.09 (IZ-CAS)。

82. Noctuidae 夜蛾科

(246) Sphragifera mioplaga Chen 小斑明夜蛾

陈一心. 1986. Acta Entomologica Sinica (昆虫学报), 29(2), 211-213. [145].

标本信息 正模: $\delta$, 湖北神农架, 1980.VII.11 (IZ-CAS)。副模: $1 \delta$, 采集时间和地点同正模 (HAAS)。

(247) Chasminodes nigrifascia Chen 黑带白夜蛾

陈一心. 1986. Acta Entomologica Sinica (昆虫学报), 29(2), 211-213. [145].

标本信息 正模: $\widehat{\jmath}$, 湖北神农架, 1980.VII.20 (IZ-CAS)。配模: ㅇ, 同正模。副模: $1 \hat{\jmath}$, 同正模 (HAAS)。

83. Tineidae 谷蛾科

(248) Matratinea trilineata Xiao et Li

Xiao YL and Li HH. 2008. Entomological News, 119(2), 207-211. [146].

标本信息 正模: つ, 甘肃文县, 2005.VI.11 (NU)。副模: 1ð, 湖北神农架, 2003.VI.19 (NU)。

84. Tortricidae 卷蛾科

(249) Antichlidas trigonia Zhang et $\mathrm{Li}$ 三角褐小卷蛾

张爱环和李后魏. 2004. Entomotaxononmia (昆虫分类学报), 26(3), 193-196. [147]. 
周友兵, 余小林, 吴楠, 申国珍, 熊高明, 徐文婷, 焚大勇, 赵常明, 谢宗强. 神农架世界自然遗产地动物模 式标本名录. 生物多样性, 2017, 25 (5): 513-517.

http://www.biodiversity-science.net/CN/10.17520/biods.2017032

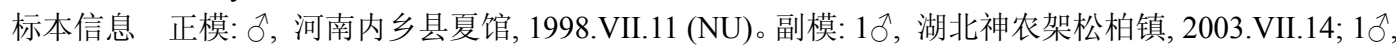

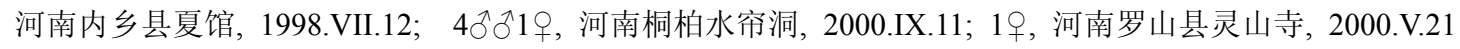
$(\mathrm{NU})$ 。

(250) Croesia lutescentis Liu et Bai 黄色弧翅卷蛾

刘友樵和白九维. 1987. Acta Entomologica Sinica (昆虫学报), 30 (3), 313-322. [148].

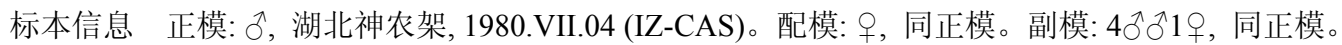

(251) Eudemis lucina Liu et Bai 鄂圆点小卷蛾

刘友樵和白九维. 1982. Entomotaxononmia (昆虫分类学报), 4(3), 167-171. [149].

标本信息 正模: 忎, 湖北神农架, 1980.VII.03 (IZ-CAS)。

(二十一) Hymenoptera 膜翅目

85. Braconidae 茧蜂科

(252) Macrocentrus longistigmus He 长痣长体茧蜂

杨星科主编. 1997. In: Insects of the Three Gorge reservoir area of Yangtze River (长江三峡库区昆虫), pp. 1659. [49].

标本信息 正模: ㅇ，湖北神农架松柏镇, 1985.IX.08。副模: 2우，四川重庆缙云山 1994.VI.13 (IZ-CAS)。

(253) Microgaster shennongjiaensis Xu, He et Li 神农架小腹茧蜂

许维岸等. 2001. Journal of Shangdong Agricultural University (Natural science) (山东农业大学学报(自然 科学版)), 32(2), 143-146. [150].

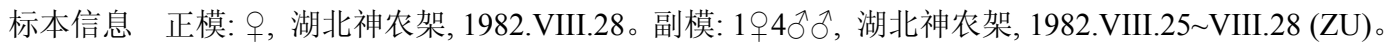

(254) Tanycarpa gymnonotum Yao

Yao JL et al. 2015. Zootaxa, 3957(2), 169-187. [151].

标本信息 正模: 9 , 湖北神农架天门垭, 2000.VIII.21 (FAFU)。副模: 10 , 湖北神农架红坪, 2000.VIII.20 (FAFU)。

86. Cephidae 茎蜂科

(255) Janus rufithorax Wei et Nie 红胸简脉茎蜂

魏美才和聂海燕. 1997. Entomotaxononmia (昆虫分类学报), 19(2), 146-152. [152].

标本信息 正模: 9 ，湖北神农架天池, 1985.VI.13 (CSUFT)。

87. Halictidae 隧蜂科

(256) Lasioglossum (Evylaeus) subversicolum Fan 拟变色淡脉隧蜂

范建国. 1992. Acta Entomologica Sinica (昆虫学报), 35(2), 234-240. [153].

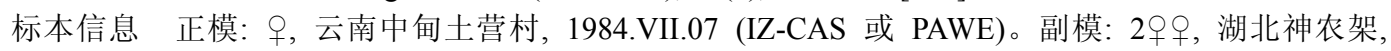

1981.VIII.01 VIII.18; 1ㅇ, 西藏墨脱西工湖, 1983.V.11 (IZ-CAS 或 PAWE)。

(257) Lasioglossum (Evylaeus) versicolum Fan 变色淡脉隧蜂

范建国. 1992. Acta Entomologica Sinica (昆虫学报), 35(2), 234-240. [153].

标本信息 正模: 9 , 湖北神农架, 1981.VII.14 (IZ-CAS 或 PAWE)。副模: 2 9 , 湖北神农架, 1981.VII.08 VII.16; 1요, 四川汶川, 1983.VII.24 (IZ-CAS 或 PAWE)。

88. Ichneunmonidae 姬蜂科

(258) Neurogenia shennongjiaensis He 神农架畸脉姬蜂

何俊华. 1985. Acta Zootaxonomica Sinica (动物分类学报), 10(3), 316-320. [154].

标本信息 正模：，，湖北神农架林区松柏镇，1983.VIII.23 (ZAFU)。配模：ふ，湖北神农架林区， 1982.VIII.25 (ZAFU)。副模: $4 \widehat{\jmath}$, 同正模。

(259) Trichomma shennongica Wang 神农毛眼姬蜂

王淑芳. 1985. Acta Zootaxonomica Sinica (动物分类学报), 10(1), 86-94. [155].

标本信息 正模: ð, 湖北神农架, 1981.V.08 (IZ-CAS)。

(260) Yamatarotes undentalis Wang 无齿辅齿姬蜂

王淑芳. 1986. Acta Entomologica Sinica, 29(2), 214-217. [156].

标本信息 正模: ㅇ, 湖北神农架, 1977.VII.26 (TNMH)。

89. Stephanidae 正冠蜂科

(261) Megischus aplicatus Hong, van Achterberg et Xu 无褶大腿冠蜂

Hong CD et al. 2010. ZooKeys, 69, 59-64. [157].

标本信息 正模: §̃, 湖北神农架自然保护区, 1982.VIII (ZU)。

90. Tenthredinidae 叶蜂科

(262) Conaspidia indistinct Wei 淡斑盾叶蜂

魏美才和聂海燕. 1997. Entomotaxononmia (昆虫分类学报), 19(Suppl.), 95-117. [158].

标本信息 正模: ㅇ, 湖北神农架，1983.VII.02 (WMCZ)。副模：2우1ð，同正模; 1ㅇ, 湖北神农架， 
周友兵, 余小林, 吴楠, 申国珍, 熊高明, 徐文婷, 焚大勇, 赵常明, 谢宗强. 神农架世界自然遗产地动物模 式标本名录. 生物多样性, 2017, 25 (5): 513-517.

http://www.biodiversity-science.net/CN/10.17520/biods.2017032

1982.VII.28 (WMCZ)。

(263) Dolerus poecilomallosis Wei 丽毛麦叶蜂

杨星科主编. 1990. In: Insects of the Three Gorge reservoir area of Yangtze River (长江三峡库区昆虫), pp. 1579. [49].

标本信息 正模: + , 福建建阳黄坑, 1960.VI.23 (IZ-CAS 或 NU)。副模: 2 9 , 湖北神农架大崖屋,

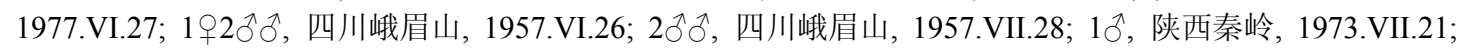
2 우3ðð, 四川巫山梨子坪, 1994.V.19; 1 \%, 湖北兴山县龙门河, 1993.VI.17 (IZ-CAS 或 NU)。

(264) Macrophya cheni Li, Liu et Wei

Li ZJ et al. 2014. Zoological Systematics, 39(4), 520-533. [159].

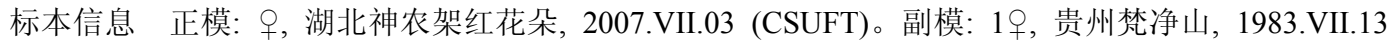
(CSUFT)。

(265) Macrophya jiangi Wei et Zhao 江氏钩瓣叶蜂

赵赴和魏美才. 2011. Acta Zootaxonomica Sinica (动物分类学报), 36(2), 264-267. [160].

标本信息 正模: ， 湖北神农架松柏, 1985.V.30 (CSUFT)。

(266) Macrophya pseudofemorata Li, Wang et Wei

Li ZJ et al. 2014. Zoological Systematics, 39 (2), 297-308. [161].

标本信息 正模: + , 湖北神农架鬼头湾, 2011.V.25 V.28 (CSUFT)。副模：1今, 采集地点同正模, 2012.V.19。

(267) Macrophya shennongjiana Wei et Zhao 神农钩瓣叶蜂

赵赴和魏美才. 2011. Acta Zootaxonomica Sinica (动物分类学报), 36(2), 264-267. [160].

标本信息 正模: 手, 神农架关峰, 1985.VIII.06 (CSUFT)。

(268) Macrophya yichangensis Li et Wei

Li ZJ et al. 2014. Zoological Systematics, 39(4), 520-533. [159].

标本信息 正模: + , 湖北神农架鬼头湾, 2011.V.25 V.28 (CSUFT)。副模: 1，湖北神农架鸭子口, 2011.V.26; 1 \% , 湖北神农架鸭子口, 2011.V.20; 10，湖北神农架小龙潭, 2011.V.24; 1 ，同正模 (CSUFT)。

(269) Nesoselandria yangi Wei 杨氏平缝叶蜂

杨星科主编. 1997. In: Insects of the Three Gorge reservoir area of Yangtze River (长江三峡库区昆虫), pp. 1567. [49].

标本信息 正模: +, 湖北神农架, 1983.VII.05 (CSUFT 或 IZ-CAS)。副模: 10̋, 湖北神农架香溪源, 1994.V.05 (CSUFT 或 IZ-CAS)。

(270) Siobla curvata Niu et Wei 弯毛侧跗叶蜂

牛耕耘等. 2012. Entomotaxononmia (昆虫分类学报), 34(2), 399-422. [162].

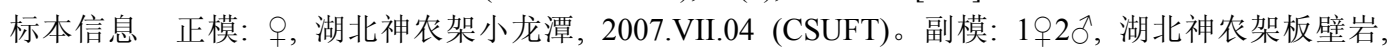
2002.VI.29; 1910 , 湖北神农架金猴岭, 2002.VI.28; 1 9 , 湖北神农架大龙潭, 2002.VI.30; 1 , 湖北神农架大 龙潭, 2008.VII.09; 10, 湖北神农架鬼头湾, 2010.V.24 V.25; 1ㅇ, 湖南壸瓶山, 2003.VI.03; 3 平, 陕西长安鸡窝 子, 2008.VI.27; 1ㅇ, 宁夏六盘山, 2008.VII.09; 10ิ, 甘肃小龙山; 10ิ, 甘肃麦积林场, 2009.V.31 (CSUFT)。

(271) Siobla listoni Niu et Wei

牛耕耘等. 2012. Entomotaxononmia (昆虫分类学报), 34(2), 399-422. [162].

标本信息 正模: ㅇ, 云南贡山, 2009.VI.12 (CSUFT 或 NSM)。副模:1今, 湖北神农架鬼头湾, 2010.V.25;

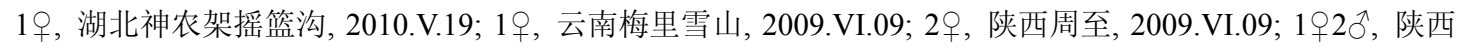
秦岭, 2007.VI.04; 1웅, 云南贡山, 2009.VI.10; 1ㅇ, 陕西秦岭, 2007.VI.07 (CSUFT 或 NSM)。

(272) Siobla qinba Niu et Wei 秦巴侧跗叶蜂

牛耕耘等. 2012. Entomotaxononmia (昆虫分类学报), 34(2), 399-422. [162].

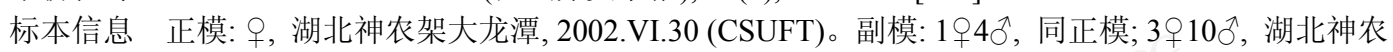

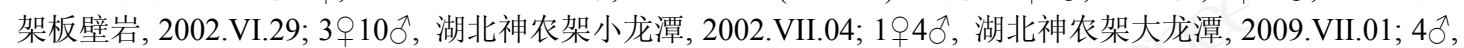

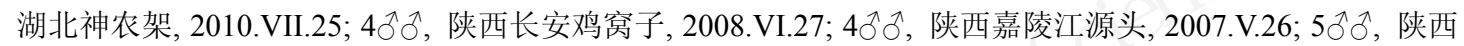
安康, 2010.VII.11 (CSUFT)。

(273) Siobla pseudoplesia Niu et Wei 柔刃侧跗叶蜂

牛耕耘等. 2012. Entomotaxononmia (昆虫分类学报), 34(2), 399-422. [162].

标本信息 正模: + , 湖北神农架板壁岩, 2002.VI.29 (CSUFT 或 NSM)。副模: 10, 同正模; 3, 湖北神

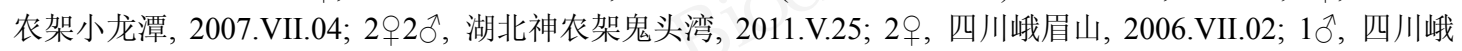
眉山, 2006.VII.27；3우，四川天泉，2003.VII.12 VII.13；1 ，四川泸定，2003.VII.15；1 ，四川泸定，

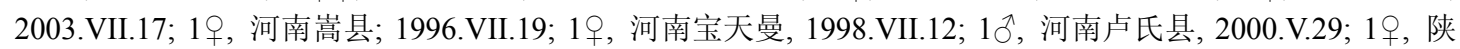
西终南山, 2006.V.27; 11우13 $\partial^{\lambda}$, 陕西龙泉, 2008.VI.24; 1ㅇ, 宁夏六盘山, 2008.VII.05; 1 9 , 陕西秦岭, 2007.VI.04 (CSUFT 或 NSM)。 
周友兵, 余小林, 吴楠, 申国珍, 熊高明, 徐文婷, 焚大勇, 赵常明, 谢宗强. 神农架世界自然遗产地动物模 式标本名录. 生物多样性, 2017, 25 (5): 513-517.

http://www.biodiversity-science.net/CN/10.17520/biods.2017032

(274) Siobla vulgaria Niu et Wei 狭项侧跗叶蜂

牛耕耘等. 2012. Entomotaxononmia (昆虫分类学报), 34(2), 399-422. [162].

标本信息 正模: 9 , 陕西嘉陵江源头, 2007.V.26 (CSUFT 或NSM)。副模: $2920 \AA$, 黑龙江伊春五营丰林, 2002.VI.26 VI.30; 4万人, 吉林长白山, 1999.VII.02; 1ठ, 吉林长白山, 1986.VII.03; 1ð, 吉林长白山,

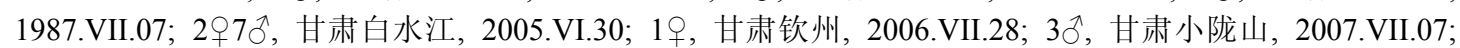
$1910 \hat{\jmath}$, 甘肃林校, 2009.VII.09; $2 \hat{\jmath}$, 甘肃天水, 2009.VII.06; 1ㅇ, 甘肃榆林沟, 2009.VIII.4; 1 吕合, 甘肃小陇

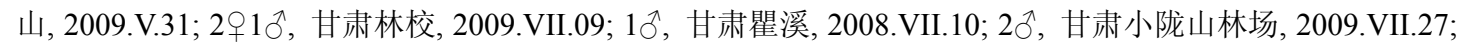

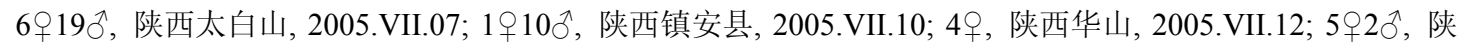

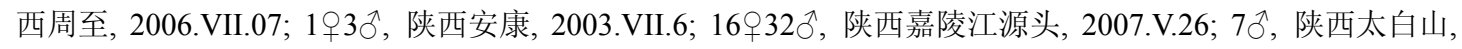
2007.VII.12; 2 2 2へ, 陕西长安鸡窝子, 2008.VI.27; 1へ, 陕西太白山, 1982.VI.30; 22へ, 河南嵩县, 1997.VII.17;

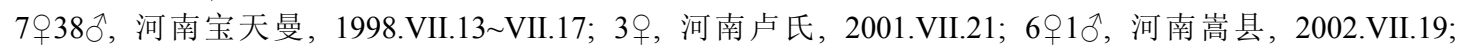

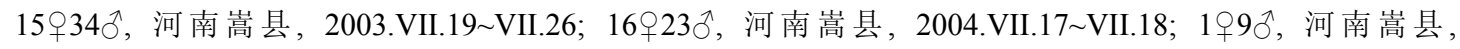
2004.VII.13; 5 $15 \hat{\jmath}$, 河南栾川, 2004.VII.21；5 +30 , 河南宝天曼, 2004.VII.24；2 +60 , 湖北神农架大龙潭,

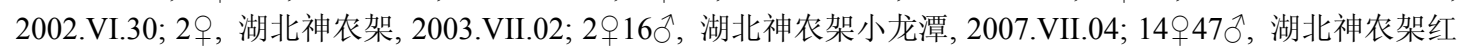
花朵, 2007.VII.03; 19, 湖北神农架神农溪, 2008.VII.10; 2ᄋ, 湖北神农架鸭子口, 2008.VII.19; 20 , 湖北神农

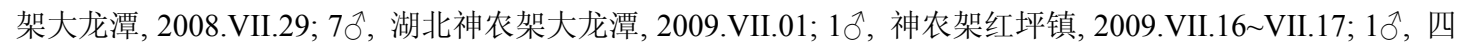

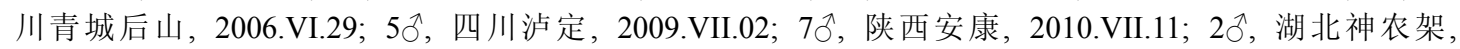
2010.VII.25; 10，陕西秦岭太白山, 2006.VI.08 (CSUFT 或 NSM)。

\section{脊索动物门 Chordata}

五、硬骨鱼纲 Osteichthyes

(二十二) Siluriformes 鲇形目

91. Gobiidae 虾虎鱼科

(275) Ctenogobius shennongensis Yang et Xie 神农栉鰕虎

杨干荣和谢从新. 1983. Zoological Research (动物学研究), 4(1), 71-74. [163].

标本信息 正模: §゙, 湖北神农架阳日关门河, 1981.VII VIII (HAU)。副模: 2 9 , , 同正模 (HAU)。 
周友兵, 余小林, 吴楠, 申国珍, 熊高明, 徐文婷, 刹大勇, 赵常明, 谢宗强. 神农架世界自然遗产地动物模 式标本名录. 生物多样性, 2017, 25 (5): 513-517.

http://www.biodiversity-science.net/CN/10.17520/biods.2017032

附录 2 神农架世界自然遗产地动物模式标本发表的原始文献

Appendix 2 Checklist of original references recording type specimens in the Shennongjia World Natural Heritage Site, China

1 Yang T (2007) Tardigrades from some mosses of Shennong Frame State Forest Park in China. Acta Zootaxonomica Sinica, 32(1), 186-190. (in Chinese with English abstract) [杨潼 (2007) 中国神农架国家森 林公园苔藓中的缓步动物. 动物分类学报, 32(1), 186-189.]

2 Scheller U (2014) New records of Pauropoda (Myriapoda) with descriptions of new taxa. Zootaxa, 3866(3), 301-332.

3 Yi TC, Jin DC (2012) Description of two new species of Woolastookia Habeeb (Acari: Hydrachnidia, Aturidae) from China. International Journal of Acarology, 38(3), 236-243.

4 Kuang HY, Hong XY (1989) Three new species of Phyllocoptinae from China (Acariformes: Eriophyidae). Journal of Nanjing Agricultural University, 12(1), 46-49. (in Chinese with English abstract) [匡海源, 洪晓月 (1989) 中国叶刺瘞螨亚科三新种记述. 南京农业大学学报, 12(1), 46-49.]

5 Liu D, Chen J (2014) Descriptions of two new species of Austrophthiracarus Balogh et Mahunka, a newly recorded genus of ptyctimous mites from China (Acari: Oribatida: Phthiracaridae). Annales Zoologici, 64(2), $267-272$.

6 Liu JY, Hu CH (2001) Two new species and a new subspecies of Acari from Hubei Province, China (Acari: Trombiculidae, Haemogamasidae). Acta Zootaxonomica Sinica, 26(3), 306-312. (in Chinese with English abstract) [刘井元, 胡翠华 (2001) 蜱螨亚纲二新种及一新亚种(蜱螨亚纲: 恙螨科, 血革螨科). 动物分 类学报, 26(3), 306-312.]

7 Liu JY, Ma LM (1998) A new species of the genus Eulaelaps from Shennongjia, northwest of Hubei Province, China (Acari: Haemogamasidae). Acta Zootaxonomica Sinica, 23(1), 21-24. (in Chinese with English abstract) [刘井元，马立名 (1998) 颚西北神农架真厉螨属一新种(蜱螨亚纲: 血革螨科). 动物分类学报, 23(1), 21-24.]

8 Liu JY, Ma LM (2002) A new species of the genus Haemogamasus and an amendment to the original description of female of Eulaelaps petauristae (Acari: Haemogamasidae). Acta Entomologica Sinica, 45(Suppl.), 118-120. (in Chinese with English abstract) [刘井元, 马立名 (2002) 血革螨属一新种记述及 对鼠鼠真厉螨雌性形态原始描述的更正(蜱螨亚纲：血革螨科). 昆虫学报, 45(增刊), 118-120.]

9 Liu JY, Ma LM (2000) Two new species of the family Laelapidae from Shennongjia of Hubei Province, China (Acari: Gamasina). Acta Zootaxonomica Sinica, 25(4), 380-383. (in Chinese with English abstract) [刘 井元，马立名 (2000) 中国厉螨科二新种记述(蜱螨亚纲: 革螨股). 动物分类学报, 25(4), 380-383.]

10 Liu JY, Wang DQ (1997) A new species of the genus Sinolaelaps from Shennongjia of Hubei Province, China (Acari: Laelapidae). Acta Zootaxonomica Sinica, 22(2), 143-146. (in Chinese with English abstract) [刘井元, 王敦清 (1997) 湖北神农架华厉螨属一新种(蜱螨亚纲: 厉螨科). 动物分类学报, 22(2), 143-146.]

11 Ma LM, Liu JY (2003) On two new species of the genus Macrocheles (Acari, Gamasina, Macrochelidae). Acta Zootaxonomica Sinica, 28(4), 657-661. (in Chinese with English abstract) [马立名, 刘井元 (2003) 巨 螯螨属二新种记述(蜱螨亚纲，革螨股，巨螯螨科). 动物分类学报, 28(4), 657-661.]

12 Ma LM, Liu JY (1998) A new species of the genus Amblygamasus from Hubei Province, China (Acari: 
周友兵, 余小林, 吴楠, 申国珍, 熊高明, 徐文婷, 刹大勇, 赵常明, 谢宗强. 神农架世界自然遗产地动物模 式标本名录. 生物多样性, 2017, 25 (5): 513-517.

http://www.biodiversity-science.net/CN/10.17520/biods.2017032

Parasitidae). Acta Zootaxonomica Sinica, 23(3), 267-269. (in Chinese with English abstract) [马立名, 刘井 元 (1998) 鄂西北钝革螨属一新种(蜱螨亚纲: 寄螨科). 动物分类学报, 23(3), 267-269.]

13 Wu WN, Li ZQ (1984) Three new species of Phytoseiidae from Shennongjia, Hubei Province (Acarina: Phytoseiidae). Acta Zootaxonomica Sinica, 9(1), 44-48. (in Chinese with English abstract) [吴伟南, 李兆权 (1984) 湖北神农架植绥螨科三新种(蜱螨目：植绥螨科). 动物分类学报, 9(1), 44-48.]

14 Wu WN, Li ZQ (1984) Three new species of the genus Phytoseius from Shennongjia, Hubei Province, south China (Acarina: Phytoseiidae). Acta Entomologica Sinica, 27(4), 457-461. (in Chinese with English abstract) [吴伟南，李兆权 (1984) 中国南方植绥螨属三新种(蜱螨目：植绥螨科). 昆虫学报, 27(4), 457-461.]

15 Ma LM, Liu JY, Ye RY (2003) New species of the genera Dendrolaelaps (Rhodacaridae) and Celaenopsis (Celaenopsidae) (Acari, Mesostigmata). Acta Zootaxonomica Sinica, 28(2), 252-255. (in Chinese with English abstract) [马立名, 刘井元, 叶瑞玉 (2003) 枝厉螨属(胭螨科)和黑面螨属(黑面螨科)各一新种 (蜱螨亚纲, 中气门亚目). 动物分类学报, 28(2), 252-255.]

16 Wang JF (1994) Three new species of Agelenid spiders from south China (Araneae: Agelenidae). Acta Zootaxonomica Sinica, 19(3), 286-292. (in Chinese with English abstract) [王家福 (1994) 中国南方漏斗蛛 三新种(蜘蛛目：漏斗蛛科). 动物分类学报, 19(3), 286-292.]

17 Wang JF, Yin CM (1992) A new genus and three new species of funnel-web spiders from south China (Araneae: Agelenidae). Journal of Natural Science of Hunan Normal University, 15(3), 263-272. (in Chinese with English abstract) [王家福, 尹长民 (1992) 我国南方漏斗蛛科一新属和三新种(蜘蛛目: 漏斗蛛科). 湖南师范大学自然科学学报, 15(3), 263-272.]

18 Zhang ZS, Zhu MS, Sun LN, Song DX (2006) Two new species of the genus Coelotes (Araneae: Amaubobiidae: Coelotinae) from Mt. Shennongjia, China. Journal of Dali University, 5(12), 1-3, 36. (in Chinese with English abstract) [张志升, 朱明生, 孙丽娜, 宋大祥 (2006) 神农架隙蛛属 Coelotes 两新种 (蜘蛛目：暗蛛科：隙蛛亚科). 大理学院学报, 5(12), 1-3, 36.]

19 Xu X, Li SQ (2007) Coelotes vestigialis sp. nov., a new species of coelotine spiders from China (Araneae, Amaurobiidae). Acta Zootaxonomica Sinica, 32(4), 756-757. (in English with Chinese abstract) [徐湘, 李枢 强 (2007) 中国隙蛛亚科蜘蛛一新种(蜘蛛目：暗蛛科). 动物分类学报, 32(4), 756-757.]

20 Zhang ZS, Zhu MS, Song DX (2002) Three new species of the subfamily Coelotinae from Mt. Shennongjia of Hubei Province, China (Araneae: Amaubobiidae). Journal of Baoding Teachers College, 15(2), 52-55. (in Chinese with English abstract) [张志升, 朱明生, 宋大祥 (2002) 湖北神农架隙蛛亚科(蜘蛛目: 暗蛛科) 三新种. 保定师范专科学校学报, 15(2), 52-55.]

21 Zhang GR, Chen J (1993) A new species of the genus Clubiona from China (Araneae: Clubionidae). Acta Zootaxonomica Sinica, 18(3), 306-308. (in Chinese with English abstract) [张古忍, 陈建 (1993) 中国管巢 蛛属一新种 (蜘蛛目: 管巢蛛科). 动物分类学报, 18(3), 306-308.]

22 Ma XL, Zhu CD (1991) A new species of spider of the genus Aprifrontalia from China (Araneae: Linyphiidae: Erigoninae). Acta Zootaxonomica Sinica, 16(2), 169-171. (in Chinese with English abstract) [马晓丽, 朱传 典 (1991) 中国吻额蛛属一新种(蜘蛛目：皿蛛科: 微蛛亚科). 动物分类学报, 16(2), 169-171.]

23 Gao JC, Zhu CD (1989) A new generic record and a new species of Linyphiidae from China (Araneae: Linyphiidae). Journal of Norman Bethune University of Medical Science, 15(3), 246-247. (in Chinese with 
周友兵, 余小林, 吴楠, 申国珍, 熊高明, 徐文婷, 樊大勇, 赵常明, 谢宗强. 神农架世界自然遗产地动物模 式标本名录. 生物多样性, 2017, 25 (5): 513-517.

http://www.biodiversity-science.net/CN/10.17520/biods.2017032

English abstract) [高久春, 朱传典(1989) 我国典蛛科一新纪录属及一新种(蜘蛛目: 皿蛛科). 白求恩医 科大学学报, 15(3), 246-247.]

24 Gao JC, Zhu CD (1988) A new species of the genus Gnathonarium from China (Araneae: Linyphiidae). Acta Zootaxonomica Sinica, 13(4), 350-352. (in Chinese with English abstract) [高久春, 朱传典 (1988) 神农架 林区额角蛛属一新种(蜘蛛目：㿼蛛科)．动物分类学报, 13(4), 350-352.]

25 Gao JC, Sha YH, Zhu CD (1989) A new species of spider of the genus Hypselistes from China (Araneae: Linyphiidae). Acta Zootaxonomica Sinica, 14(4), 424-426. (in Chinese with English abstract) [高久春, 沙玉 华，朱传典 (1989) 神农架林区闪腹蛛属一新种(蜘蛛目：血蛛科). 动物分类学报, 14(4), 424-426.]

26 Li SQ, Zhu CD (1989) A new species of the spider genus Lepthyphantes from Shennongjia Forest Region, China (Araneae: Linyphiidae). Journal of Norman Bethune University of Medical Science, 15(1), 38-39. (in Chinese with English abstract) [李枢强, 朱传典 (1989) 神农架林区斑血蛛属一新种(蜘蛛目: 皿蛛科). 白求恩医科大学学报, 15(1), 38-39.]

27 Li SQ, Zhu CD (1995) Five new species of Linyphlld spiders from China (Araneae: Linyphlldae). Acta Zootaxonomica Sinica, 20(1), 39-48. (in Chinese with English abstract) [李枢强, 朱传典 (1995) 神农架林 区皿蛛科蜘蛛五新种记述(蛛形纲：蜘蛛目).动物分类学报, 20(1), 39-48.]

28 Gao JC, Zhu CD, Gao YQ (1993) Two new generic records and two new species of Erigoninae from China (Araneae: Linyphiidae: Erigoninae). Journal of Norman Bethune University of Medical Science, 19(1), 40-42. (in Chinese with English abstract) [高久春, 朱传典, 高元奇 (1993) 中国微蛛亚科二新纪录属和二新种 (蜘蛛目：典蛛科：微蛛亚科). 白求恩医科大学学报, 19(1), 40-42.]

29 Chen J, Zhu CD (1989) Two new species of the genus Neriene from Hubei, China (Araneae: Linyphiidae). Acta Zootaxonomica Sinica, 14(2), 160-165. (in Chinese with English abstract) [陈建, 朱传典 (1989) 湖北 省盖蛛属二新种(蜘蛛目：皿蛛科). 动物分类学报, 14(2), 160-165.]

30 Chen J, Zhu CD (1988) A new species of spider of the genus Neriene from Hubei, China (Araneae: Linyphiidae). Acta Zootaxonomica Sinica, 13(4), 346-349. (in Chinese with English abstract) [陈建, 朱传典 (1988) 神农架林区盖蛛属一新种(蜘蛛目：典蛛科). 动物分类学报, 13(4), 346-349.]

31 Ma XL, Zhu CD (1991) One new species of the spider genus Oedothorax from China (Araneae: Linyphiidae: Erigoninae). Acta Zootaxonomica Sinica, 16(1), 27-29. (in Chinese with English abstract) [马晓丽, 朱传典 (1991) 中国瘤胸蛛属一新种(蜘蛛目：血蛛科：微蛛亚科). 动物分类学报, 16(1), 27-29.]

32 Ma XL, Zhu CD (1990) Two new species of spiders of the genus Oedothorax from China (Araneae: Linyphiidae: Erigoninae). Acta Zootaxonomica Sinica, 15(4), 431-435. (in Chinese with English abstract) [马 晓丽, 朱传典 (1990) 中国瘤胸蛛属二新种(蜘蛛目：血蛛科：微蛛亚科). 动物分类学报, 15(4), 431-435.]

33 Li S, Zonstein S (2015) Eight new species of the spider genera Raveniola and Sinopesa from China and Vietnam (Araneae, Nemesiidae). ZooKeys, 519, 1-32.

34 Jäger P, Gao J, Fei R (2002) Sparassidae in China 2. Species from the collection in Changchun (Arachnida: Araneae). Acta Arachnologica, 51(1), 23-31.

35 Peng XJ, Yin CM, Kim JP (1996) One species of the genus Heteropoda and a description of the female Heteropoda minschana Schenkel, 1936 (Araneae: Heteropodidae). Korean Arachnology, 12 (1), 57-61. 
周友兵, 余小林, 吴楠, 申国珍, 熊高明, 徐文婷, 刹大勇, 赵常明, 谢宗强. 神农架世界自然遗产地动物模 式标本名录. 生物多样性, 2017, 25 (5): 513-517.

http://www.biodiversity-science.net/CN/10.17520/biods.2017032

36 Yin WY (1987) A preliminary survey on protura from Shennongjia, Hubei Province, with descriptions of three new species. Entomotaxonomia, 9(1), 77-84. (in Chinese with English abstract) [尹文英 (1987) 湖北 神农架原尾虫初查及三新种一新记录的记录. 昆虫分类学报, 9(1), 77-84.]

37 Zhang HM, Cai QH (2014) Aeshna shennong sp nov., a new species from Hubei Province, China (Odonata: Anisoptera: Aeshnidae). Zootaxa, 3795(4), 489-493. Zhang HM, Cai QH, Liao MY (2013) Three new Cephalaeschna species from central China with descriptions of the hitherto unknown sex of related species (Odonata: Aeshnidae). International Journal of Odonatology, 16(2), 157-176.

39 Zhang HM, Vogt TE, Cai QH (2013) Somatochlora shennong sp. nov. from Hubei, China (Odonata: Corduliidae). Zootaxa, 3878(5), 479-484.

40 Yang D, Yang JK (1993) New and little-known species of Plecoptera from Guizhou Province (III). Entomotaxononmia, 15(4), 235-238. (in Chinese with English abstract) [杨定，杨集昆 (1993) 贵州省襀翅 目昆虫之三(襀翅目：襀科，卷襀科). 昆虫分类学报, 15(4), 235-238.]

41 Sivec I, Harper PP, Shimizu T (2008) Contribution to the study of the Oriental genus Rhopalopsole (Plecoptera: Leuctridae). Scopolia, 64, 1-122.

42 Qian YH, Li HL, Du YZ (2014) A study of Leuctridae (Insecta: Plecoptera) from Shennongjia, Hubei Province, China. Florida Entomologist, 97(2), 605-610.

43 Yang D, Yang JK (1991) New species of Plecoptera from Hubei. Journal of Hubei University (Natural Science), 13(4), 369-372. (in Chinese with English abstract) [杨定, 杨集昆 (1991) 湖北襀翅目新种及新 纪录. 湖北大学学报(自然科学版), 13(4), 369-372.]

44 Wang YW (1995) Two new species of the genus Caryanda Stål 1878 from Hubei Province, China (Orthoptera: Catantopidae). Acta Zootaxonomica Sinica, 20(1), 81-85. (in Chinese with English abstract) [王裕文 (1995) 湖北省卵翅蝗属二新种(直翅目: 斑腿蝗科). 动物分类学报, 20(1), 81-85.]

45 Zheng ZM (1997) Two new species of the genus Pielomastax Chang (Orthoptera: Eumastacoidea) from China. Entomotaxonomia, 19(1), 13-16. (in Chinese with English abstract) [郑哲民 (1997) 中国比蜢属二新种记 述(直翅目: 蜢总科). 昆虫分类学报, 19(1), 13-16.]

46 Wang YW (1995) A new species of the genus Pielomastax Chang 1937 from Shennongjia, Hubei Province (Orthoptera: Eumastacoidea). Acta Zootaxonomica Sinica, 20(2), 204-206. (in Chinese with English abstract) [王裕文 (1995) 湖北神农架比蜢属一新种(直翅目：蜢总科). 动物分类学报, 20(2), 204-206.]

47 Xia KL, Liu XW (1989) Descriptions of five new species of Eumastacoidea from China (Orthoptera). Entomotaxonomia, 11(4), 253-258. (in Chinese with English abstract) [夏凯龄, 刘宪伟 (1989)中国蜢总科 五新种记述(直翅目：蜢总科). 昆虫分类学报, 11(4), 253-258.]

48 Chang YL, Zheng ZM (1997) One new species of the genus Bulbistridulous (Orthoptera: Tettigonioidea) and its karyology. Entomotaxonomia, 19(1), 10-12. (in Chinese with English abstract) [常岩林, 郑哲民 (1997) 鼓鸣蚉属一新种及染色体核型研究(直翅目：蚉斯总科). 昆虫分类学报, 19(1), 10-12.]

49 Yang XK (1997) Insects of the Three Gorge Reservoir Area of Yangtze River. Chongqing Publishing House, Chongqing. (in Chinese with English abstract) [杨星科 (1997) 长江三峡库区昆虫. 重庆出版社, 重庆.]

50 Wang YW, Liu XW (1996) Description of new species of the genus Shirakisotima from China (Orthoptera: 
周友兵, 余小林, 吴楠, 申国珍, 熊高明, 徐文婷, 焚大勇, 赵常明, 谢宗强. 神农架世界自然遗产地动物模 式标本名录. 生物多样性, 2017, 25 (5): 513-517.

http://www.biodiversity-science.net/CN/10.17520/biods.2017032

Tettigonioidea: Phaneropteridae). Journal of Shandong University (Natural Science), 31(3), 336-340. (in Chinese with English abstract) [王裕文, 刘宪伟 (1996) 中国素木虫属的新种记述(直翅目: 蚉斯总科: 露 蚉科). 山东大学学报(自然科学版), 31(3), 336-340.]

51 Gorochov AV, Rampini M, Russo CD (2006) New species of the genus Diestrammena (Orthoptera: Rhaphidophoridae: Aemodogryllinae) from caves of China. Russian Entomological Journal, 15(4), 355-360.

52 Zheng ZM, Li K, Wei CM (2002) Brief descriptions of three new species from Shennongjia district. Acta Entomologica Sinica, 45(5), 644-647. (in Chinese with English abstract) [郑哲民, 李恺, 魏朝明 (2002) 神 农架地区虾科三新种记述. 昆虫学报, 45(5), 644-647.]

53 Chen JX, Ji SL, Wu HR (1984) Description of a new species of Rhadinopsylla Jordan et Rothschild (Siphonaptera: Hystrichopsyllidae). Acta Zootaxonomica Sinica, 9(1), 82-84. (in Chinese with English abstract) [陈家贤, 纪树立, 吴厚永 (1984) 纤蚤属一新种记述(蚤目: 多毛蚤科). 动物分类学报, 9(1), 82-84.]

54 Feng JN, Yang XN, Zhang GL (2007) Taxonomic study of the genus Heliqnothrips from China (Thysanoptera, Thripidae). Acta Zootaxonomica Sinica, 32(2), 451-454. (in Chinese with English abstract) [冯纪年, 杨晓娜, 张桂玲 (2007) 中国领针蓟马属的分类研究(缨翅目, 蓟马科). 动物分类学报, 32(2), 451-454.]

55 Li ZZ, Yang LH (2002) A systematic study on the genus Bundera Distant (Homoptera: Cicadellidae: Evacanthinae). Acta Zootaxonomica Sinica, 27(3), 548-555. [李子忠, 杨玲环 (2002) 斜脊叶蝉属系统分 类研究(同翅目: 叶蝉科: 横脊叶蝉亚科). 动物分类学报, 27(3), 548-555.]

56 Shen L, Zhang YL (1995) Two new species of the genus Balala Distant (Homoptera: Cicadellidae: Hylicinae) from China. Entomotaxonomia, 17(4), 271-274. (in English with Chinese abstract) [沈林, 张雅林 (1995) 片胫杆蝉属二新种(同翅目：叶蝉科：杆叶蝉亚科). 昆虫分类学报, 17(4), 271-274.]

57 Yuan F, Tian RG, Xu QY (1997) A new genus and four new species of membracidae (Homoptera) from China. Entomotaxonomia, 19(3), 185-190. (in English with Chinese abstract) [袁锋, 田润刚, 徐秋园 (1997) 中国 角蝉科一新属四新种. 昆虫分类学报, 19(3), 185-190.]

58 Zhou Y, Yuan F, Liang AP (1986) Taxonomic and phylogenesis of Sinophora (Homoptera: Aphrophoridae). Entomotaxonomia, 8(1/2), 97-111. (in Chinese with English abstract) [周尧, 袁锋, 梁爱萍 (1986) 华沫蝉 属的分类及其系统发育(同翅目: 尖胸沫蝉科). 昆虫分类学报, 8(1/2), 97-111.]

59 Yang PL, Lü CR, Zhan CC (1986) Matsucoccus Shennongjiaensis Young et Lu, N. SP. (Coccoidea: Margarodidae). Contributions from Shanghai Institute Entomology, 6, 195-198. (in Chinese with English abstract) [杨平澜, 吕昌仁, 詹仲才 (1986) 神农架松干蚧新种(蚧总科: 珠蚧科). 昆虫学研究集刊, 6, 195-198.]

60 Liu SL (1979) Acanthosomatidae from west Hubei Province, China (Hemiptera). Entomotaxonomia, 1(1), 55-59. (in Chinese with English abstract) [刘胜利 (1979) 鄂西神农架的同蝽(半翅目: 同蝽科). 昆虫分类 学报, 1(1), 55-59.]

61 Liu SL (1981) New species of the Chinese Aradidae (Hemiptera-Heteroptera: Aradidae). Acta Entomologica Sinica, 24(2), 184-187. (in Chinese with English abstract) [刘胜利 (1981) 中国扁蝽科的新种(半翅目: 异 翅亚目). 昆虫学报, 24(2), 184-187.]

62 Liu SL (1980) New species of Mezirinae from China (Hemiptera-Heteroptera: Aradidae). Acta 
周友兵, 余小林, 吴楠, 申国珍, 熊高明, 徐文婷, 刹大勇, 赵常明, 谢宗强. 神农架世界自然遗产地动物模 式标本名录. 生物多样性, 2017, 25 (5): 513-517.

http://www.biodiversity-science.net/CN/10.17520/biods.2017032

Zootomologica Sinica, 5(2), 175-184. (in Chinese with English abstract) [刘胜利 (1980) 中国短喙扁蝽亚 科新种记述(半翅目: 扁蝽科). 动物分类学报, 5(2), 175-184.]

63 Li H, Dai R-H, Li Z-Z (2016) The leafhopper genus Onukigallia Ishihara, 1955 with descriptions of two new species from southern China (Hemiptera, Cicadellidae, Megophthalminae, Agalliini). ZooKeys, 622, 85-93.

64 Zhou HG, Zheng LY (1980) A preliminary study on Chinese Emphanisis (Hemiptera: Lygaeidae). Acta Zootaxonomica Sinica, 5(4), 404-408. (in Chinese with English abstract) [邹环光, 郑乐怡 (1980) 中国古 铜长蝽属记述(半翅目: 长蝽科). 动物分类学报, 5(4), 404-408.]

65 Lü N, Zheng LY (1998) A taxonomic study on the genus Arbolygus (Heteroptera · Miridae) from China. Entomotaxononmia, 20(2), 79-96. (in English with Chinese abstract) [吕楠, 郑乐怡 (1998) 中国树丽盲蝽 属分类研究(半翅目: 盲蝽科). 昆虫分类学报, 20(2), 79-96.]

66 Zheng LY, Wang XJ (1983) New species and new records of Lygus (subg. Apolygus) from China (Hemiptera: Miridae). Acta Zootaxonomica Sinica, 8(4), 422-429. (in Chinese with English abstract) [郑乐怡, 汪兴鉴 (1983) 中国丽盲蝽属 Apolygus 亚属新种及新纪录(半翅目：盲蝽科). 动物分类学报, 8(4), 422-429.]

67 Liu Q, Zheng LY (1994) One Chinese species of Plautia Stål (Hemiptera: Pentatomidae). Entomotaxononmia, 16(4), 235-248. (in Chinese with English abstract) [刘强, 郑乐怡 (1994) 珀蝽属中国种类记述(半翅目: 蝽科). 昆虫分类学报, 16(4), 235-248.]

68 Yang JK, Wang XX (1990) Eight new species of green lacewings from Hubei Province (Neuroptera: Chrysopidae). Journal of Hubei University (Natural Science), 12(2), 154-163. (in Chinese with English abstract) [杨集昆, 王象贤 (1990) 湖北省的草蛉区系(脉翅目: 草岭科). 湖北大学学报(自然科学版), 12(2), 154-163.]

69 Yang Y, Su J, Yang X (2014) Description of six new species of Lycocerus Gorham (Coleoptera, Cantharidae), with taxonomic note and new distribution data of some other species. ZooKeys, 456, 85-107.

70 Shi H, Liang H (2015) The genus Pterostichus in China. II. the subgenus Circinatus Sciaky, a species revision and phylogeny (Carabidae, Pterostichini). ZooKeys, 536, 1-92.

71 Facchini S, Sciaky R (2003) Five new species of Pterostichinae from Hubei (China). Koleopterologische Rundschau, 73, 7-17.

72 Pu FJ (1985) Three new species of the genus Distenia from China (Coleoptera: Cerambycidae). Acta Zootaxonomica Sinica, 10(4), 427-430. (in Chinese with English abstract) [蒲富基 (1985) 瘦天牛属三新种 (鞘翅目: 天牛科). 动物分类学报, 10(4), 427-430.]

73 Pu FJ (1986) A new species of the genus Eutetrapha from Shennongjia, Hubei, China (Coleoptera: Cerambycidae, Lamiinae). Acta Zootaxonomica Sinica, 11(2), 201-202. (in Chinese with English abstract) [蒲富基 (1986) 湖北神农架直脊天牛属一新种(鞘翅目：天牛科). 动物分类学报, 11(2), 201-202.]

74 Chen SC (1991) A new species of genus Necydalis from Shennongjia, Hubei, China (Coleoptera: Cerambycidae). Acta Entomologica Sinica, 34(3), 344-345. (in Chinese with English abstract) [陈树椿 (1991) 湖北神农架膜天牛属一新种(鞘翅目：天牛科). 昆虫学报, 34(3), 344-345.]

75 Wang WK, Chiang SN (1994) New species and new records of Lepturid beetles (Coleoptera: Cerambycidae) from China. Entomotaxonomia, 16(3), 192-196. (in Chinese with English abstract) [王文凯, 蒋书楠 (1994) 中国花天牛亚科新种及新记录(鞘翅目：天牛科). 昆虫分类学报, 16(3), 192-196.] 
周友兵, 余小林, 吴楠, 申国珍, 熊高明, 徐文婷, 焚大勇, 赵常明, 谢宗强. 神农架世界自然遗产地动物模 式标本名录. 生物多样性, 2017, 25 (5): 513-517.

http://www.biodiversity-science.net/CN/10.17520/biods.2017032

76 Ge S, Daccordi M, Yang X (2007) Two new species of the genus Gonioctena Chevrolat from China (Coleoptera: Chrysomelidae: Chrysomelinae). Genus, 18(4), 579-587.

77 Jiang SQ (1989) Four new Chinese species of Japonitata (Coleoptera: Chrysomelidae, Galerucinae). Acta Entomologica Sinica, 32(2), 221-225. (in Chinese with English abstract) [姜胜巧 (1989) 中国日萤叶甲属 四新种(鞘翅目：叶甲科，萤叶甲亚科). 昆虫学报, 32(2), 221-225.]

78 Chen SX, Wang SY, Jiang SQ (1985) A new genus of Galerucinae from west China (Coleoptera: Chrysomelidae). Acta Zoologica Sinica, 31(4), 372-376. (in Chinese with English abstract) [陈世骧, 王书永, 姜胜巧 (1985) 华西萤叶甲之一新属(鞘翅目：叶甲科). 动物学报, 31(4), 372-376.]

79 Ge S-Q, Daccordi M, Beutel RG, Li W-Z, Yang X-K (2011) Revision of the chrysomeline genera Potaninia, Suinzona and Taipinus (Coleoptera) from eastern Asia, with a biogeographic scenario for the Hengduan Mountain region in south-western China. Systematic Entomology, 36, 644-671.

80 Jing XL (1986) Two new species of the genus Asemiadalia (Coleoptera: Coccinellidae). Acta Zootaxonomica Sinica, 11(2), 205-208. (in Chinese with English abstract) [经希立 (1986) 突角慓虫属二新种记述(鞘翅目: 慓虫科). 动物分类学报, 11(2), 205-208.]

81 Ren SX, Pang XF (1993) Two new species of Scymnus Kugelann from Hubei (Coleoptera: Coccinellidae). Journal of South China Agricultural University, 14(3), 6-9. (in English with Chinese abstract) [任顺祥, 庞雄 飞 (1993) 湖北小毛漂虫属二新种记述(鞘翅目: 漂虫科). 华南农业大学学报, 14(3), 6-9.]

82 Chen X, Huo L, Wang X, Canepari C, Ren S (2015) The subgenus pullus of scymnus from China (Coleoptera, Coccinellidae). Part II: The impexus group. Annales Zoologici, 65(3), 295-408.

83 Chen X, Huo L, Wang X, Ren S (2015) The subgenus Pullus of Scymnus from China (Coleoptera, Coccinellidae). Part I. The Hingstoni and Subvillosus groups. Annales Zoologici, 65(2), 187-237.

84 Schimmel R, Tarnawski D (2012) New and little known species of the genus Zorochros Thomson 1859 (Coleoptera: Elateridae) from Palaearctic and Oriental Region. Annales de la Société entomologique de France (Nouvelle série), 48 (3-4), 347-362.

85 Wang CB, Zhou HZ (2015) Taxonomy of the genus Ptomaphaginus Portevin (Coleoptera: Leiodidae: Cholevinae: Ptomaphagini) from China, with description of eleven new species. Zootaxa, 3941(3), 301-338.

86 Zeng H (1986) Four new species of the genus Hoplia from China (Coleoptera: Melolonthidae). Entomotaxonomia, 8(4), 271-275. (in Chinese with English abstract) [曾虹 (1986) 单爪鳃蛖属四新种记述 (鞘翅目: 鳃角金龟科). 昆虫分类学报, 8(4), 271-275.]

87 Liu WG, Fabrizi S, Bai M, Yang XK, Ahrens D (2014) A taxonomic revision of the Neoserica (sensu lato) pilosula group (Coleoptera, Scarabaeidae, Sericini). ZooKeys, 440, 89-113

88 Cai YP, Zhao ZY, Zhou HZ (2015) Taxonomy of the genus Bolitogyrus Chevrolat (Coleoptera: Staphylinidae: Staphylinini: Quediina) from China with description of seven new species. Zootaxa, 3955(4), 451-486.

89 Puthz V (2015) Synopsis of the species of the genus Dianous Leach group II. (Coleoptera, Staphylinidae). Linzer Biologische Beitraege, 48(1), 705-778.

90 Li X-Y, Solodovinikov A, Zhou H-Z (2013) Four new species of the genus Lobrathium Mulsant \& Rey (Coleoptera: Staphylinidae: Paederinae) from China. Zootaxa, 3635(5), 569-578.

91 Assing V (2016) A revision of Zyras Stephens sensu strictu of China, with records and (re-) descriptions of 
周友兵, 余小林, 吴楠, 申国珍, 熊高明, 徐文婷, 焚大勇, 赵常明, 谢宗强. 神农架世界自然遗产地动物模 式标本名录. 生物多样性, 2017, 25 (5): 513-517.

http://www.biodiversity-science.net/CN/10.17520/biods.2017032

some species from other regions (Coleoptera: Staphylinidae: Aleocharinae: Lomechusini). Stuttgarter Beiträge zur Naturkunde A (Neue Serie), 9, 87-175.

92 Schawaller W (2008) The genus Laena Latreille (Coleoptera: Tenebrionidae) in China (part 2), with descriptions of 30 new species and a new identification key. Stuttgarter Beiträge zur Naturkunde Serie A (Neue Serie), 1, 387-411.

93 Schawaller W (2001) The genus Laena Latreille (Coleoptera: Tenebrionidae) in China, with descriptions of 47 new species. Stuttgarter Beiträge zur Naturkunde Serie A (Biologie), 632, 1-62.

94 Chen J, Tan J, Hua B (2013) Review of the Chinese Bittacus (Mecoptera: Bittacidae) with descriptions of three new species. Journal of Natural History, 47(21-22), 1463-1480.

95 Du JP, Yang JK, Yao G, Yang D (2008) Seventeen new species of Bombyliidae from China(Diptera). In: Classification and Distribution of Insects in China (eds Shen XC, Zhang RZ, Ren YD), pp. 3-19. China Agricultural Science and Technology Press, Beijing. (in Chinese with English abstract) [杜进平, 杨集昆, 姚 刚, 杨定 (2008) 中国蜂虹科十七个新种(双翅目). 见: 昆虫分类与分布(申效诚, 张润志, 任应党主编), pp. 3-19. 中国农业科学技术出版社, 北京.]

96 Yang JY, Yang D (2014) A new species of Oocelyphus (Diptera: Celyphidae). Entomotaxonomia, 36(1), 55-60. (in English with Chinese abstract) [杨金英, 杨定 (2014) 卵甲蝇属一新种记述(双翅目: 甲蝇科). 昆虫分类学报, 36(1), 55-60.]

97 Liu X, Yang D (2014) Five new species of Centorisoma Becker from China, with an updated key to world species (Diptera, Chloropidae). Zootaxa, 3821(1), 101-115.

98 Wang MQ, Chen HY, Yang D (2014) New species of Nepalomyia henanensis species group from China (Diptera: Dolichopodidae: Peloropeodinae). Zoological Systematics, 39(3), 411-416.

99 Shao ZF, Li T, Jiang JJ, Lu JM, Chen HW (2014) Molecular phylogenetic analysis of the Amiota taurusata species group within the Chinese species, with descriptions of two new species. Journal of Insect Science, 14, 33.

100 Yang D, Yang JK (1990) Eight new species of the genus Chelipoda from China (Diptera: Empididae). Acta Zootaxonomica Sinica, 15(4), 483-488. (in Chinese with English abstract) [杨定, 杨集昆 (1990) 中国䯽螳 舞虹属八新种(双翅目: 舞虻科). 动物分类学报, 15(4), 483-488.]

101 Liu XY, Li Z, Yang D (2010) New species of subgenus Coptophlebia from Shennongjia, Hubei (Diptera, Empididae). Acta Zootaxonomica Sinica, 35(4), 736-741. (in English with Chinese abstract) [刘晓艳, 李竹, 杨定 (2010) 湖北神农架缺脉舞虹亚属五新种(双翅目, 舞虹科). 动物分类学报, 35(4), 736-741.]

102 Li Z, Cui WN, Yang D (2010) Five new species of Hilara from Shennongjia, Hubei (Diptera, Empididae). Acta Zootaxonomica Sinica, 35(4), 745-749. (in English with Chinese abstract) [李竹, 崔维娜, 杨定 (2010) 湖北神农架喜舞虻属五新种(双翅目, 舞虻科). 动物分类学报, 35(4), 745-749.]

103 Liu QF, Li Z, Yang D (2010) Six new species of Hilara (Diptera: Empididae) from Shennongjia, Hubei. Entomotaxonomia, 32(Suppl.), 61-70. (in English with Chinese abstract) [刘启飞, 李竹, 杨定 (2010) 湖北 神农架喜舞虹属六新种(双翅目: 舞虹科). 昆虫分类学报, 32(增刊), 61-70.]

104 Liu QF, Li Z, Yang D (2010) New species of Hilara (Diptera: Empididae) from Hubei, China. Entomotaxonomia, 32(3), 195-200. (in English with Chinese abstract) [刘启飞, 李竹, 杨定 (2010) 湖北喜 
周友兵, 余小林, 吴楠, 申国珍, 熊高明, 徐文婷, 焚大勇, 赵常明, 谢宗强. 神农架世界自然遗产地动物模 式标本名录. 生物多样性, 2017, 25 (5): 513-517.

http://www.biodiversity-science.net/CN/10.17520/biods.2017032

舞虹属新种记述(双翅目: 舞虻科). 昆虫分类学报, 32(3), 195-200.]

105 Yang JK, Yang D (1991) New species of Hybos Meigen from Hubei (Diptera: Empididae). Journal of Hubei University (Natural Science), 13(1), 1-8. (in Chinese with English abstract) [杨集昆, 杨定 (1991) 湖北省 的驼舞虬及新种记述(双翅目: 舞虻科). 湖北大学学报(自然科学版), 13(1), 1-8.]

106 Huo S, Zhang J, Yang D (2010) Two new species of Hybos from Hubei, China (Diptera: Empididae). Transactions of the American Entomological Society, 136(3+4), 251-254.

107 Huo S, Zhang J, Yang D (2010) Two new species of Platypalpus from Oriental China (Dipera: Empidida). Transactions of the American Entomological Society, 136(3+4), 259-262.

108 Yu H, Liu QF, Yang D (2010) Two new species of subgenus Rhamphomyia from China (Diptera: Empididae). Acta Zootaxonomica Sinica, 35(3), 475-477. (in English with Chinese abstract) [余慧，刘启飞，杨定 (2010) 中国猎舞虹亚属二新种(双翅目, 舞虻科). 动物分类学报, 35(3), 475-477.]

109 Zhou D, Li Y, Yang D (2010) A new genus and species of Empididae from China (Diptera, Empidoidea). Acta Zootaxonomica Sinica, 35(3), 478-480. (in English with Chinese abstract) [周丹, 李彦, 杨定 (2010) 中国舞虻科一新属一新种(双翅目, 舞虻总科). 动物分类学报, 35(3), 478-480.]

110 Yang JK, Wu H (1989) Three new species of Mycetophilids from Hubei (Diptera: Mycetophilidae). Journal of Hubei University (Natural Science), 11(2), 61-64. (in Chinese with English abstract) [杨集昆, 吴鸿 (1989) 湖北省的菌蚊记三新种(双翅目：菌蚊科). 湖北大学学报(自然科学版), 11(2), 61-64.]

111 Shi L, Yang D (2014) Five new species of Minettia (Minettiella) (Diptera, Lauxaniidae) from China. ZooKeys, 449, 81-103.

112 Shi L, Gaimari SD, Yang D (2015) Five new species of subgenus Plesiominettia (Diptera, Lauxaniidae, Minettia) in southern China, with a key to known species. ZooKeys, 520, 61-86.

113 Shi L, Yang D (2014) Three new species of subgenus Frendelia (Diptera: Lauxaniidae: Minettia) in Southern China, with a key to known species worldwide. Florida Entomologist, 97(4), 1511-1528.

114 Yang JK, Yang D (1991) Five new species of Rhagionidae from Hubei (Diptera: Brachycera). Journal of Hubei University (Natural Science), 13(3), 273-277. (in Chinese with English abstract) [杨集昆, 杨定 (1991) 湖北省㗈虹科 5 新种(双翅目: 短角亚目). 湖北大学学报(自然科学版), 13(3), 273-277.]

115 Huang J, Shi K, Li Z, Wu H (2015) Review of the genus Pseudozygoneura Steffan (Diptera, Sciaridae) from China. Entomological News, 125(2), 77-95.

116 Huang J, Shi K, Zhang SJ, Wu H (2014) Taxonomy of the genus Peyerimhoffia Kieffer from Mainland China, with a description of seven new species (Diptera, Sciaridae). ZooKeys, 382, 67-83.

117 Yang M, Chen HB, Luo HB (2009) A characteristic new blackfly species from Shennongjia Natural Reserve, China (Diptera, Simuliidae). Acta Zootaxonomica Sinica, 34(3), 454-456. (in English with Chinese abstract) [杨明, 陈汉涁, 罗洪斌 (2009) 湖北神农架自然保护区一新特蚋种(双翅目, 蚋科). 动物分类学报, 34(3), 454-456.]

118 Chen HB, Luo HB, Yang M (2006) First listed of blackflies with two new species from Shennongjia, Hubei Province, China (Diptera, Simuliidae). Acta Zootaxonomica Sinica, 31(4), 874-879. (in English with Chinese abstract) [陈汉彬, 罗洪斌, 杨明 (2006) 湖北省神农架蚋类记要并记述二新种(双翅目, 蚋科). 动物分 类学报, 31(4), 874-879.] 
周友兵, 余小林, 吴楠, 申国珍, 熊高明, 徐文婷, 刹大勇, 赵常明, 谢宗强. 神农架世界自然遗产地动物模 式标本名录. 生物多样性, 2017, 25 (5): 513-517.

http://www.biodiversity-science.net/CN/10.17520/biods.2017032

119 Li Z, Zhang TT, Yang D (2011) Four new species of Allognosta from China (Diptera, Stratiomyidae). Acta Zootaxonomica Sinica, 36(2), 273-277. (in English with Chinese abstract) [李竹, 张婷婷, 杨定 (2011) 中 国距水虻属四新种(双翅目，水虹科). 动物分类学报, 36(2), 273-277.]

120 Li Z, Luo CM, Yang D (2009) Two species of Beris latreille (Diptera: Stratiomyidae) from Hubei. Entomotaxonomia, 31(2), 129-131. (in English with Chinese abstract) [李竹, 罗春梅, 杨定 (2009) 湖北柱 角水虹属二种记述(双翅目: 水虹科). 昆虫分类学报, 31(2), 129-131.]

121 Xu RM, Ni T, Xu XD (1984) Two new species of Tabanus from Hubei, China. Journal of Wuhan Medical College, 13(3), 164-166. (in Chinese with English abstract) [许荣满, 倪涛, 许先典 (1984) 湖北虹属二新 种记述(双翅目: 虻科). 武汉医学院学报, 13(3), 164-166.]

122 Yang D, Yang JK (1989) Four new species of the genus Dictenidia (Diptera: Tipulidae). Acta Agriculturae Universitatis Pekinensis, 15(1), 69-73. (in Chinese with English abstract) [杨定, 杨集昆 (1989) 中国偶栉 大蚊属四新种(双翅目：大蚊科). 北京农业大学学报, 15(1), 69-73.]

123 Liu Q, Yang D (2011) Three new species of the genus Macgregoromyia Alexander, with a key to world species (Diptera, Tipulidae). Zootaxa, 2802, 41-50.

124 Yang JK, Yang D (1987) The Nephrotoma species of Hubei Province (Diptera: Tipulidae). Journal of Huazhong Agricultural University, 6(2), 130-137. (in Chinese with English abstract) [杨集昆, 杨定 (1987) 湖北省短柄大蚊属新种及新记录(双翅目: 大蚊科). 华中农业大学学报, 6(2), 130-137.]

125 Yang JK, Yang D (1988) Six new species of genus Tanyptera from China (Diptera: Tipulidae). Journal of Hubei University (Natural Science), 10(2), 70-74. (in Chinese with English abstract) [杨集昆, 杨定 (1988) 中国奇栉大蚊属六新种(双翅目：大蚊科). 湖北大学学报(自然科学版), 10(2), 70-74.]

126 Yang JK, Yang D (1992) Five new species of Crane flies from Hubei (Diptera: Tipulidae). Journal of Hubei University (Natural Science), 14(3), 263-269. (in Chinese with English abstract) [杨集昆, 杨定 (1992) 湖 北省大蚊新记录属种及 5 新种(双翅目: 大蚊科). 湖北大学学报(自然科学版), 14(3), 263-269.]

127 Yang D, Yang JK (1999) Two new species of Tipula from Hubei (Diptera: Tipulidae). Journal of China Agricultural University, 4(Suppl.), 63-64. (in Chinese with English abstract) [杨定，杨集昆 (1999) 湖北大 蚊属二新种(双翅目: 大蚊科). 中国农业大学学报, 4(增刊), 63-64.]

128 Yang D, Yang JK (1991) Three new species of Tipula from Sichuan (Diptera: Tipulidae). Journal of Southwest Agricultural University, 13(3), 252-254. (in Chinese with English abstract) [杨定，杨集昆 (1991) 四川大蚊属三新种(双翅目：大蚊科). 西南农业大学学报, 13(3), 252-254.]

129 Wang XJ (1989) A new genus and three new species of Acanthonevrini from China (Diptera: Tephritidae). Acta Zootaxonomica Sinica, 14(3), 358-363. (in Chinese with English abstract) [汪兴鉴 (1989) 刺脉实蝇 族一新属三新种(双翅目: 实蝇科). 动物分类学报, 14(3), 358-363.]

130 Liu JY, Wang DH (1994) Description of a new species of the genus Macrostylophora (Siphonaptera, Ceratophyllidae). Acta Zootaxonomica Sinica, 19(2), 238-242. (in Chinese with English abstract) [刘井元, 王敦清 (1994) 大锥蚤属一新种记述(蚤目: 角叶蚤科). 动物分类学报, 19(2), 238-242.]

131 Wang DQ, Liu JY (1993) A new flea of the genus Ctenophthalmus Kolenati, 1856 (Siphonaptera: Hystrichopsyllidae). Acta Zootaxonomica Sinica, 18(4), 490-492. (in Chinese with English abstract) [王敦清, 刘井元 (1993) 栉眼蚤属一新种记述(蚤目: 多毛蚤科). 动物分类学报, 18(4), 490-492.] 
周友兵, 余小林, 吴楠, 申国珍, 熊高明, 徐文婷, 刹大勇, 赵常明, 谢宗强. 神农架世界自然遗产地动物模 式标本名录. 生物多样性, 2017, 25 (5): 513-517.

http://www.biodiversity-science.net/CN/10.17520/biods.2017032

132 Liu JY, Chen SQ (2005) A new species of the genus Palaeopsylla Wagner from Shennongjia, northwest of Hubei, China (Siphonaptera, Ctenophthalmidae). Acta Zootaxonomica Sinica, 30(1), 194-198. (in Chinese with English abstract) [刘井元, 陈尚全 (2005) 湖北西北部神农架古蚤属一新种(蚤目, 栉眼蚤科). 动物 分类学报, 30(1), 194-198.]

133 Wang DQ, Liu JY (1995) Description of a new species of Stenischia Jordan (Siphonaptera: Hystrichopsyllidae). Acta Zootaxonomica Sinica, 20(3), 363-365. (in Chinese with English abstract) [王敦清, 刘井元 (1995) 狭臀蚤属一新种记述(蚤目: 多毛蚤科). 动物分类学报, 20(3), 363-365.]

134 Wang DQ, Liu JY (1995) Description of a new species of Geusibia Jordan,1932 (Siphonaptera: Leptopsyllidae). Acta Zootaxonomica Sinica, 20(1), 112-115. (in Chinese with English abstract) [王敦清, 刘 井元 (1995) 茸足蚤属一新种记述(蚤目: 细蚤科). 动物分类学报, 20(1), 112-115.]

135 Liu JY, Wang DQ (1995) A new species of Typhlomyopsyllus Li et Huang, 1980 from Hubei Province, China (Siphonaptera: Leptopsyllidae). Acta Zootaxonomica Sinica, 20(2), 243-245. (in Chinese with English abstract) [刘井元, 王敦清 (1995) 盲鼠蚤属一新种记述(蚤目: 细蚤科). 动物分类学报, 20(2), 243-245.]

136 Liu JY (1997) A new species of Chaetopsylla Kohaut,1903 from Hubei Province, China (Siphonaptera: Vermipsyllidae). Acta Entomologica Sinica, 40(1), 82-85. (in Chinese with English abstract) [刘井元 (1997) 中国鬃蚤属一新种记述(蚤目：蠕形蚤科). 昆虫学报, 40(1), 82-85.]

137 Fang CL (1991) Studies of the genus Miltochrista of China (Lepidoptera: Arctiidae: Lithosiinae). Sinozoologia, 8, 383-397. (in Chinese with English abstract) [方承莱 (1991) 中国美苔蛾属的研究(鳞翅目: 灯蛾科: 苔蛾亚科). 动物学集刊, 8, 383-397.]

138 Chu HF, Wang LY (1987) A successive report on the Chinese Drepaninae (Lepidoptera: Drepanidae). Genera: Albara, Auzatella, Paralbara, Strepsigonia, Deroca, Cilix and Pseudalbara. Sinozoologia, 5, 105-122. (in Chinese with English abstract) [朱弘复, 王林瑶 (1987) 中国钩蛾亚科续报(鳞翅目: 钩蛾科). I. Albara; II. Auzatella; III. Paralbara; IV. Strepsigonia; V. Deroca; VI. Cilix; VII. Pseudalbara. 动物学集刊, 5, 105-122.]

139 Chu HF, Wang LY (1987) On the Chinese Drepaninae (Lepidoptera: Drepanidae). Betalbara, Drepana and Canucha. Sinozoologia, 5, 73-88. (in Chinese with English abstract) [朱弘复, 王林瑶 (1987) 中国钩蛾亚 科续报(鳞翅目: 钩蛾科). 卑钩蛾属 Betalbara Matsumura, 1927; 镰钩蛾属 Drepana Schrank, 1802; 枯叶 钩蛾属 Canucha Walker, 1866. 动物学集刊, 5, 73-88.]

140 Chu HF, Wang LY (1988) On the Chinese Drepaninae (Lepidoptera: Drepanidae) genus Nordstroemia Bryk, 1943. Acta Entomologica Sinica, 31(3), 309-316. (in Chinese with English abstract) [朱弘复, 王林瑶 (1988) 中国钩蛾亚科线钩蛾属(鳞翅目: 钩蛾科). 昆虫学报, 31(3), 309-316.]

141 Chu HF, Wang LY (1987) Studies on the taxonomy and zoogeography of the Chinese Oretinae (Lepidoptera: Drepanidae). Acta Entomologica Sinica, 30(3), 291-307. (in Chinese with English abstract) [朱弘复, 王林瑶 (1987) 中国山钩蛾亚科分类及地理分布. 昆虫学报, 30(3), 291-307.]

142 Chen XY (1985) Notes on the two new species of Drepanidae (Lepidoptera) from China. Entomotaxononmia, 7(4), 277-280. (in Chinese with English abstract) [陈小钰 (1985) 钩蛾科二新种记述. 昆虫分类学报, 7(4), 277-280.]

143 Fang XL, Wang M (2004) Notes on the genus Lobocia Moore with description of a new species 
周友兵, 余小林, 吴楠, 申国珍, 熊高明, 徐文婷, 刹大勇, 赵常明, 谢宗强. 神农架世界自然遗产地动物模 式标本名录. 生物多样性, 2017, 25 (5): 513-517.

http://www.biodiversity-science.net/CN/10.17520/biods.2017032

(Lepidoptera, Hesperiidae). Acta Zootaxonomica Sinica, 29(3), 523-526. (in English with Chinese abstract) [范骁凌，王敏 (2004) 带弄蝶属研究(鳞翅目，弄蝶科). 动物分类学报, 29(3), 523-526.]

144 Fang CL (1986) New species of the genus Agylla from China (Lepidoptera: Arctiidae: Lithosiinae). Sinozoologia, 4, 180-182. (in Chinese with English abstract) [方承莱 (1986) 华苔蛾属新种记述(鳞翅目: 灯蛾科: 苔蛾亚科). 动物学集刊, 4, 180-182.]

145 Chen YX (1986) New species of Noctuidae from China (Lepidoptera). Acta Entomologica Sinica, 29(2), 211-213. (in Chinese with English abstract) [陈一心 (1986) 夜蛾科新种记述. 昆虫学报, 29(2), 211-213.]

146 Xiao Y, Li H (2008) The genus Matratinea is new to China, with descriptions of two new species (Lepidoptera: Tineidae). Entomological News, 119(2), 207-211.

147 Zhang AH, Li HH (2004) Taxonomic study on the genus Antichlidas (Lepidoptera: Tortricidae: Olethreutinae), with description of a new species. Entomotaxonomia, 26(3), 193-196. (in English with Chinese abstract) [张爱环, 李后魂 (2004) 褐小卷蛾属分类研究及一新种记述(鳞翅目: 卷蛾科: 新小卷 蛾亚科). 昆虫分类学报, 26(3), 193-196.]

148 Liu YQ, Bai JW (1987) On the Chinese Croesia Hübner (Lepodoptera: Tortricidae) with descriptions of five new species. Acta Entomologica Sinica, 30(3), 313-322. (in Chinese with English abstract) [刘友樵, 白九维 (1987) 中国弧翅卷蛾属研究及新种记述. 昆虫学报, 30(3), 313-322.]

149 Liu YQ, Bai JW (1982) Three new species of Sorolophae Diakonoff 1973 from China (Lepidoptera: Tortricidae). Entomotaxononmia, 4(3), 167-171. (in Chinese with English abstract) [刘友樵, 白九维 (1982) 中国尾小卷蛾亚族三新种(鳞翅目：卷蛾科)．昆虫分类学报, 4(3), 167-171.]

150 Xu WA, He JH, Li SJ (2001) One new species of Microgaster Latreilie (Hymenoptera) from China. Journal of Shangdong Agricultural University (Natural Science), 32(2), 143-146. (in Chinese with English abstract) [许维岸, 何俊华, 李淑君 (2001) 小腹茧蜂属一新种和一新记录种(膜翅目: 茧蜂科: 小腹茧蜂亚科). 山东农业大学学报(自然科学版), 32(2), 143-146.]

151 Yao J, Kula RR, Wharton RA, Chen J (2015) Four new species of Tanycarpa (Hymenoptera, Braconidae, Alysiinae) from the Palaearctic Region and new records of species from China. Zootaxa, 3957(2), 169-187.

152 Wei MC, Nie HY (1997) Studies on Chinese Cephidae IV-four new species of Janus Stephens with a list of Chinese Cephidae (Hymenoptera) Entomotaxononmia, 19(2), 146-152. (in Chinese with English abstract) [魏 美才, 聂海燕 (1997) 中国茎蜂科分类研究 IV. 简脉茎蜂属四新种附中国茎蜂科种属名录(膜翅目: 茎 蜂科). 昆虫分类学报, 19(2), 146-152.]

153 Fan JG, Ebmer PAW (1992) Nine new species of Lasioglossum (Evylaeus) from China (Hymenoptera: Apoidea, Halictiade). Acta Entomologica Sinica, 35(2), 234-240. (in Chinese with English abstract) [范建国, Ebmer PAW (1992) 中国胫淡脉隧蜂亚属九新种(膜翅目: 蜜蜂总科, 隧蜂科). 昆虫学报, 35(2), 234-240.]

154 He JH (1985) Descriptions of three species of Neurogenia Roman from China. Acta Zootaxonomica Sinica, 10(3), 316-320. (in Chinese with English abstract) [何俊华 (1985) 中国畸脉姬蜂属三新种记述(膜翅目: 姬蜂科). 动物分类学报, 10(3), 316-320.]

155 Wang SF (1985) Notes on Chiese Trichomma Wesmael (Ichneumonidae: Anomalinae). Acta Zootaxonomica Sinica, 10(1), 86-94. (in Chinese with English abstract) [王淑芳 (1985) 中国毛眼姬峰属记述(姬蜂科: 肿 
周友兵, 余小林, 吴楠, 申国珍, 熊高明, 徐文婷, 焚大勇, 赵常明, 谢宗强. 神农架世界自然遗产地动物模 式标本名录. 生物多样性, 2017, 25 (5): 513-517.

http://www.biodiversity-science.net/CN/10.17520/biods.2017032

跗姬蜂亚科). 动物分类学报, 10(1), 86-94.]

156 Wang SF (1986) New species of Chinese Yamatarotes Uchida (Hymenoptera: Ichneumonidae, Acaenitinae). Acta Entomologica Sinica, 29(2), 214-217. (in Chinese with English abstract) [王淑芳 (1986) 中国辅齿姬 蜂属纪要(膜翅目: 姬蜂科, 犁姬蜂亚科). 昆虫学报, 29(2), 214-217.]

157 Hong C-D, van Achterberg C, Xu Z-F (2010) A new species of Megischus Brullé (Hymenoptera, Stephanidae) from China, with a key to the Chinese species. ZooKeys, 69, 59-64.

158 Wei MC, Nie HY (1997) Studies on the genus Conaspidia Konow (Hymenoptera: Tenthredinidae) from China with a key to known species of the world. Entomotaxononmia, 19(Suppl.), 95-117. (in English with Chinese abstract) [魏美才, 聂海燕 (1997) 中国盾叶蜂属研究附世界已知各检索表(膜翅目: 叶蜂科). 昆 虫分类学报, 19(增刊), 95-117.]

159 Li Z-J, Liu M-M, Wei M-C (2014) Four new species of sanguinolenta-group of the genus Macrophya (Hymenoptera: Tenthredinidae) from China. Zoological Systematics, 39(4), 520-533.

160 Zhao F, Wei MC (2011) Two new species of Macrophya Dahlbom (Hymenoptera, Tenthredinidae) from Shennongjia, China. Acta Zootaxonomica Sinica, 36(2), 264-267. (in English with Chinese abstract) [赵赴, 魏美才 (2011) 神农架钩瓣叶蜂属二新种(膜翅目, 叶蜂科). 动物分类学报, 36(2), 264-267.]

161 Li Z-J, Lei Z, Wang J-F, Wei M-C (2014) Three new species of sanguinolenta-group of the genus Macrophya (Hymenoptera: Tenthredinidae) from China. Zoological Systematics, 39(2), 297-308.

162 Niu GY, Xiao W, Wei MC (2012) Seven new species and a key to species of Siobla (Hymenoptera: Tenthrdeinidae) from Shaanxi, China. Entomotaxononmia, 34(2), 399-422. (in English with Chinese abstract) [牛耕耘, 肖炜, 魏美才 (2012) 中国陕西侧跗叶蜂属七新种及分种检索表(膜翅目: 叶蜂科). 昆虫分类 学报, 34(2), 399-422.]

163 Yang GR, Xie CX (1983) A new species of fishs from mount Shennong. Zoological Research, 4(1), 71-74. (in Chinese with English abstract) [杨干荣, 谢从新 (1983) 神农架鱼类一新种. 动物学研究, 4(1), 71-74.] 
周友兵，余小林，吴楠，申国珍，熊高明，徐文婷，焚大勇，赵常明，谢宗强. 神农架世界自然遗产地动物模式标本名录. 生物多样性, 2017, 25 (5): 513-517.

http://www.biodiversity-science.net/CN/10.17520/biods.2017032

\section{附录 3 神农架世界自然遗产地动物模式标本存放地中英文名称及缩写}

Appendix 3 List of abbreviation, Chinese and English names of deposit sites of animal type specimens collected from the Shennongjia World Natural Heritage Site

\begin{tabular}{|c|c|c|c|c|}
\hline 发表文献中列出标本存放地名称 & 当前存放单位中文名称 & 当前存放单位英文名称 & 名称缩写 & 存放物种数量 \\
\hline Names of deposit sites in primary literatures & Chinese name of current deposit sites & English name of current deposit sites & Abbreviation & Number \\
\hline 四川省阿坝藏族自治州卫生防疫站 & 阿坝州疾病预防控制中心 & Aba Center for Diseases Prevention and Control, China & ACDPC & 1 \\
\hline 军事医学科学院微生物流行病研究所 & & & & \\
\hline $\begin{array}{l}\text { 军事医学科学院微生物流行病研究所医学昆虫标 } \\
\text { 本馆 } \\
\text { 中国军事医学科学院 }\end{array}$ & 军事医学科学院 & Academy of Military Medical Sciences, China & AMMS & 7 \\
\hline 北京林业大学昆虫标本室 & 北京林业大学 & Beijing Foresty University, China & $\mathrm{BFU}$ & 1 \\
\hline $\begin{array}{l}\text { 中国医学科学院流行病微生物学研究所 } \\
\text { 北京农业大学昆虫标本室 }\end{array}$ & 中国医学科学院 & Chinese Academy of Medical Science, China & CAMS & 1 \\
\hline 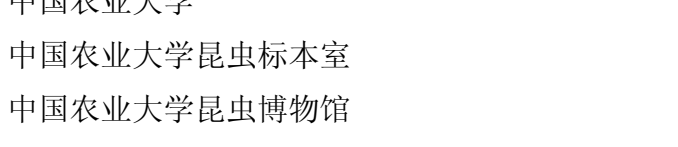 & 中国农业大学 & China Agricultural University, China & CAU & 83 \\
\hline $\begin{array}{l}\text { 中南林学院 } \\
\text { 中南林学院环境与资源系昆虫标本室 } \\
\text { 中南林业科技大学昆虫标本馆 }\end{array}$ & 中南林业科技大学 & $\begin{array}{l}\text { Central South University of Forestry and Technology, } \\
\text { China }\end{array}$ & CSUFT & 12 \\
\hline 福建农林大学益虫研究所 & 福建农林大学 & Fujian Agriculture \& Forestry University, China & FAFU & 1 \\
\hline 福建医学院医学昆虫研究室 & 福建医科大学 & Fujian Medical University, China & FMC & 4 \\
\hline 广东省昆虫研究所 & 广东省生物资源应用研究所 & $\begin{array}{l}\text { Guangdong Institute of Applied Biological Resources, } \\
\text { China }\end{array}$ & GIAPR & 4 \\
\hline 贵阳医学院生物学教研室 & 贵州医科大学 & Guizhou Medical University, China & GMU & 3 \\
\hline 贵州大学昆虫研究所 & 贵州大学 & Guizhou University, China & GU & 3 \\
\hline 湖北省农业科学院植物保护研究所 & 湖北省农业科学院 & Hubei Academy of Agricultural Science, China & HAAS & 2 \\
\hline
\end{tabular}


周友兵，余小林，吴楠，申国珍，熊高明，徐文婷，奘大勇，赵常明，谢宗强. 神农架世界自然遗产地动物模式标本名录. 生物多样性，2017，25 (5): 513-517.

http://www.biodiversity-science.net/CN/10.17520/biods.2017032

附录 3 (续)

\begin{tabular}{|c|c|c|c|c|}
\hline 发表文献中列出标本存放地名称 & 当前存放单位中文名称 & 当前存放单位英文名称 & 名称缩写 & 存放物种数量 \\
\hline Names of deposit sites in primary literatures & Chinese name of current deposit sites & English name of current deposit sites & & \\
\hline \multicolumn{5}{|l|}{ 湖北省武汉医学科学院寄生虫病研究所 } \\
\hline $\begin{array}{l}\text { 湖北省医学科学院寄生虫病研究所 } \\
\text { 湖北省医学科学院寄生虫病研究所媒介昆虫 } \\
\text { 研究室 }\end{array}$ & 湖北省预防医学科学院 & Hubei Academy of Medical Sciences, China & HAMS & 15 \\
\hline 华中农学院水产系 & 华中农业大学 & Huazhong Agricultural University, China & HAU & 1 \\
\hline 湖北武昌湖北林校 & 湖北生态工程职业技术学院 & Hubei Ecology Vocational College, China & HEVC & 1 \\
\hline 湖南省生物研究所 & 湖南省农业科学院 & Hunan Academy of Agricultural Sciences, China & HNAAS & 3 \\
\hline 匈牙利自然史博物馆 & 匈牙利自然史博物馆 & Hungarian Natural History Museum, Budapest, Hungary & HNHM & 1 \\
\hline 湖南师范大学 & 湖南师范大学 & Hunan Normal University, Changsha, China & $\mathrm{HNU}$ & 1 \\
\hline 河北大学博物馆 & 河北大学 & Hebei University, China & $\mathrm{HU}$ & 7 \\
\hline $\begin{array}{l}\text { 中国科学院水生生物研究所 } \\
\text { 中国科学院动物研究所标本馆 }\end{array}$ & 中国科学院水生生物研究所 & Institute of Hydrobiology, Chinese Academy of Sciences, China & IH-CAS & 6 \\
\hline $\begin{array}{l}\text { 中国科学院动物研究所 } \\
\text { 中国科学院动物研究所国家动物博物馆 } \\
\text { 中国科学院动物研究所昆虫博物馆 }\end{array}$ & 中国科学院动物研究所 & Institute of Zoology, Chinese Academy of Sciences, China & IZ-CAS & 54 \\
\hline 吉林大学 & 吉林大学 & Jilin University, China & $\mathrm{JU}$ & 1 \\
\hline $\begin{array}{l}\text { 西北农林科技大学昆虫博物馆 } \\
\text { 西北农业大学昆虫博物馆 }\end{array}$ & 西北农林科技大学 & Northwest A \& F University, China & NAFU & 5 \\
\hline 南京农业大学植保系 & 南京农业大学 & Nanjing Agricultural University,China & NAU & 3 \\
\hline $\begin{array}{l}\text { 白求恩医科大学生物教研室 } \\
\text { 白求恩医科大学生物学教研室 }\end{array}$ & 吉林大学白求恩医学部 & $\begin{array}{l}\text { Norman Bethune Health Science Center of Jilin University, } \\
\text { China }\end{array}$ & NBHSC-JU & 18 \\
\hline 伦敦自然历史博物馆 & 伦敦自然历史博物馆 & The Natural History Museum, London, United Kingdom & NHML & 1 \\
\hline
\end{tabular}


周友兵，余小林，吴楠，申国珍，熊高明，徐文婷，㚞大勇，赵常明，谢宗强. 神农架世界自然遗产地动物模式标本名录. 生物多样性，2017，25 (5): 513-517.

http://www.biodiversity-science.net/CN/10.17520/biods.2017032

附录 3 (续)

\begin{tabular}{|c|c|c|c|c|}
\hline $\begin{array}{l}\text { 发表文献中列出标本存放地名称 } \\
\text { Names of deposit sites in primary literatures }\end{array}$ & $\begin{array}{l}\text { 当前存放单位中文名称 } \\
\text { Chinese name of current deposit sites }\end{array}$ & $\begin{array}{l}\text { 当前存放单位英文名称 } \\
\text { English name of current deposit sites }\end{array}$ & $\begin{array}{c}\text { 名称缩写 } \\
\text { Abbreviation }\end{array}$ & $\begin{array}{l}\text { 存放物种数量 } \\
\text { Number }\end{array}$ \\
\hline 瑞士国立自然博物馆 & 瑞士国立自然博物馆 & Naturhistorisches Museum, Basel, Switzerland & NMB & 1 \\
\hline 奥地利维也纳自然史博物馆 & 奥地利维也纳自然史博物馆 & Naturhistorisches Museum, Wien, Austria & NMW & 3 \\
\hline $\begin{array}{l}\text { 日本国立博物馆 } \\
\text { 南开大学生命科学学院昆虫标本室 }\end{array}$ & 日本国立博物馆 & National Science Museum, Tokyo, Japan & NSM & 3 \\
\hline $\begin{array}{l}\text { 南开大学生物系 } \\
\text { 南开大学生物系昆虫标本室 } \\
\text { 华南农业大学昆虫标本室 }\end{array}$ & 南开大学 & Nankai University, China & NU & 8 \\
\hline $\begin{array}{l}\text { 华南农业大学 } \\
\text { 华南农业大学昆虫学系 } \\
\text { 上海昆虫研究所 }\end{array}$ & 华南农业大学 & South China Agricultural University, Guangzhou, China & SCAU & 8 \\
\hline $\begin{array}{l}\text { 上海昆虫博物馆 } \\
\text { 中国科学院上海昆虫研究所 }\end{array}$ & 上海昆虫博物馆 & Shanghai Entomological Museum, China & SEM & 10 \\
\hline 德国国家自然博物馆 & 德国国家自然博物馆 & Staatliches Museum für Naturkunde, Stuttgart/Germany & SMN & 2 \\
\hline $\begin{array}{l}\text { 陕西师范大学动物研究所 } \\
\text { 陕西师范大学动物研究所标本室 }\end{array}$ & 陕西师范大学 & Shaanxi Normal University, China & SNU & 5 \\
\hline 上海师范大学 & 上海师范大学 & Shanghai Normal University, China & SHNU & 1 \\
\hline 山东大学生物系 & 山东大学 & Shandong University, China & SU & 3 \\
\hline 西南农业大学昆虫分类研究室 & 西南大学 & Southwest University, China & SWU & 1 \\
\hline 武汉医学院 & 华中科技大学同济医学院 & $\begin{array}{l}\text { Tongji Medical College of Huazhong University of Science } \\
\text { and Technology, China }\end{array}$ & TMC-HUST & 1 \\
\hline 天津自然博物馆 & 天津自然博物馆 & Tianjin Natural Museum History, China & TNMH & 6 \\
\hline 扬州大学应用昆虫所 & 扬州大学 & Yangzhou University, China & YU & 2 \\
\hline
\end{tabular}


周友兵, 余小林, 吴楠，申国珍，熊高明，徐文婷，牀大勇，赵常明，谢宗强. 神农架世界自然遗产地动物模式标本名录. 生物多样性，2017，25 (5): 513-517.

http://www.biodiversity-science.net/CN/10.17520/biods.2017032

附录 3 (续)

\begin{tabular}{|c|c|c|c|c|}
\hline $\begin{array}{l}\text { 发表文献中列出标本存放地名称 } \\
\text { Names of denosit sites in primary literatures }\end{array}$ & $\begin{array}{l}\text { 当前存放单位中文名称 } \\
\text { Chinese name of current deposit sites }\end{array}$ & $\begin{array}{l}\text { 当前存放单位英文名称 } \\
\text { English name of current deposit sites }\end{array}$ & $\begin{array}{c}\text { 名称缩写 } \\
\text { Abbreviation }\end{array}$ & $\begin{array}{l}\text { 存放物种数量 } \\
\text { Number }\end{array}$ \\
\hline 浙江农林大学森林保护研究所 & & & & \\
\hline 浙江农业大学生物防治研究室 & 浙江农林大学 & Zhejiang A \& F University, China & ZAFU & 4 \\
\hline 德国柯尼希博物馆 & 德国柯尼希博物馆 & Zoologisches Forschungsmuseum A. Koenig, Bonn, Germany & ZFKB & 1 \\
\hline 俄罗斯科学院动物研究所 & 俄罗斯科学院动物研究所 & Zoological Institute, Russian Academy of Science, St. Petersburg & ZI-RAS & 1 \\
\hline 瑞典隆德大学动物博物馆 & 瑞典隆德大学动物博物馆 & Zoological Museum, Lund University, Sweden & ZML & 1 \\
\hline 浙江大学植物保护系寄生蜂标本室 & 浙江大学 & Zhejiang Univesity, China & $\mathrm{ZU}$ & 2 \\
\hline 奥地利林茨 Ebmer 收藏 & & P. Andreas Werner Ebmer collection, Linz, Austria & PAWE & 2 \\
\hline 奥地利维也纳 Schuh 收藏 & & Rudolf Schuh collection, Wien, Austria & CSW & 1 \\
\hline 波兰弗罗茨瓦夫 Warchałowski 收藏 & & Andrzej Warchałowski collection, Wrocław, Poland & CWW & 1 \\
\hline 德国柏林 Schülke 收藏 & & Michael Schülke collection, Berlin, Germany & CSB & 3 \\
\hline 德国菲宁根 Schimmel 收藏 & & Rainer Schimmel collection, Vinnigen, Germany & CSV & 1 \\
\hline 德国汉诺威 Assing 收藏 & & Volker Assing collection, Hannover, Germany & $\mathrm{CAH}$ & 2 \\
\hline 德国荷索金劳勒 Kippenberg 收藏 & & Horst Kippenberg collection, Herzogenaurach, Germany & $\mathrm{CKH}$ & 1 \\
\hline 德国柏林 Wrase 收藏 & & David Wrase collection, Berlin, Germany & CWB & 3 \\
\hline 法国凡尔赛 Bergeal 收藏 & & Michel Bergeal collection, Versailles, France & $\mathrm{CBV}$ & 1 \\
\hline 湖南株洲魏美才收藏 & & Wei Meicai collection, Zhuzhou, Hunan, China & WMCZ & 1 \\
\hline 加拿大渥太华 Smetana 收藏 & & Aleš Smetana collection, Ottawa, Canada & CSO & 3 \\
\hline 捷克科斯泰莱茨 Turna 收藏 & & Jaroslav Turna collection, Kostelec Na Hane, Czech Republic & СТK & 1 \\
\hline 日本福冈 Maruyama 收藏 & & Munetoshi Maruyama collection, Fukuoka, Japan & $\mathrm{CMF}$ & 1 \\
\hline 意大利米兰 Sciaky 收藏 & & Riccardo Sciaky collection, Milano, Italy & CSM & 5 \\
\hline 意大利皮亚琴察 Facchini 收藏 & & Sergio Facchini collection, Piacenza, Italy & CFP & 5 \\
\hline 意大利维罗纳 Daccordi 收藏 & & Mauro Daccordi collection, Verona, Italy & $\mathrm{CDV}$ & 3 \\
\hline 意大利维罗纳 Toledano 收藏 & & Luca Toledano collection, Verona, Italy & CTV & 1 \\
\hline
\end{tabular}

